\title{
THE MAGIC OF THE QUEEN OF EGYPT IN THE ROSE "CLEOPATRA"
}

\author{
Pet'ko Lyudmila \\ Candidate of Pedagogic Sciences, Associate Professor \\ Dragomanov National Pedagogical University
}

\section{Faut Maria}

Student of Faculty of Natural and Geographical Education and Ecology Dragomanov National Pedagogical University

\author{
Age cannot wither her, nor custom stale her infinite variety \\ William Shakespeare, Antony and Cleopatra, ACT 2 SCENE 2
}

\begin{abstract}
Presented a new approach to the training future teachers, including Science (biology, botany, etc.) through the prism of the rose named after the last pharaoh of Egypt, Queen Cleopatra. The authors consider the Cleopatra rose not through the preparation of a plant in the laboratory (while scientific botanists search to know flowers physiologically and morphologically in the spirit of progress and truth,), but reveal the secrets and magic of the Cleopatra rose through the knowledge of "life truths", thus forming professionally oriented foreign language educational space at university (foreign language, history, geography, philosophy, chemistry, art (A.S. Arensky's ballet "Egyptian Nights", operas "Cléopâtre" by Massenet and "Giulio Cesare in Egitto" by Haendel), cinema, literature, psychology), involving students in romantic love, the ability to understand the flower codes inherent in the Cleopatra rose. We use floral codes strategically in their fiction as subtexts for practitioners of the language of flowers.

Key words: Queen Cleopatra, rose Cleopatra, Julius Caesar, Mark Anthony, Rome, Egypt, Dante, Shakespeare, Haggard, Handel, company W. Kordes \& Söhne rose (Germany), students, foreign language, university.
\end{abstract}

Our project group (Fig. 2) explores the roses named after famous people and this article presents the Cleopatra rose and it's heroine (Fig. 3, 4), see video [124].
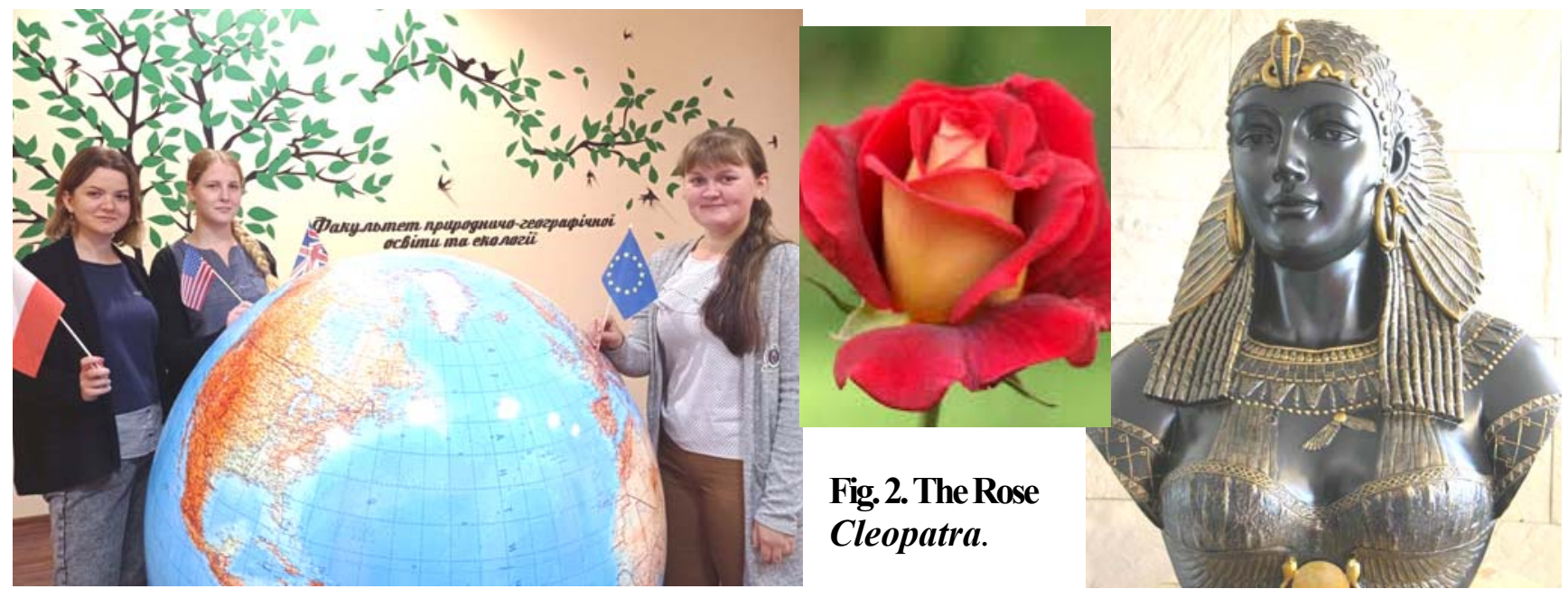

Fig. 1. Novak T. [91; 128], Faut M. [96; 98], and Holovko T. [74; 75; 97]. Fig. 3. The Bust of Cleopatra. 
Cleopatra is a mystery all in herself, very little is known about the Egyptian Queen... It is said that she commited suicide by placing a poisonous snake upon her body and allowing it to bite her and ultimately kill her. But there are other theories that focus on different death, and theories that somehow counteract others while supporting something completely different. Cleopatra is a enigma, and the whole theory of who she is, what she looked like, how she died and where she is buried is something we know very little about...[75], see video [124[.

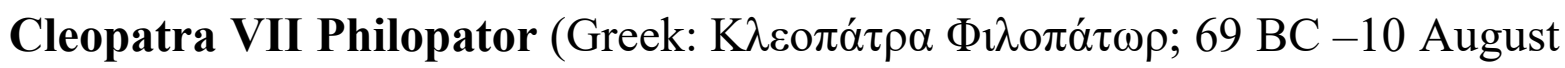
30 BC), often referred to simply as Cleopatra, was Queen of the Ptolemaic Kingdom of Egypt (Fig. 4, 5), and its last active ruler [104].

A member of the Ptolemaic dynasty, she was a descendant of its founder Ptolemy I Soter (Fig. 7) a Macedonian Greek general and companion of Alexander the Great (Fig. 8). Cleopatra was a daughter of Ptolemy XII (Auletes) (Fig. 6). After the death of Cleopatra, Fig. 4 Ptolemaic Egypt circa 235 BC [123]. Egypt became a province of the Roman Empire, marking the end of the second to last Hellenistic state and the age that had lasted since the reign of Alexander (336-323 BC). Her native language was Koine Greek, and she was the only Ptolemaic ruler to learn the Egyptian language [51], see videos $[4 ; 120]$.

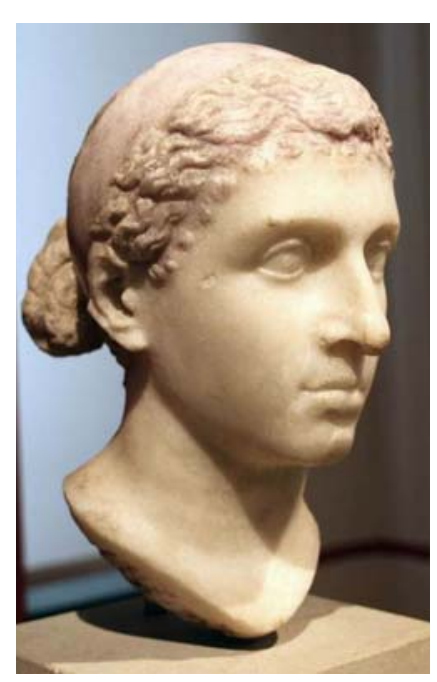

Fig. 5. The Berlin Cleopatra.
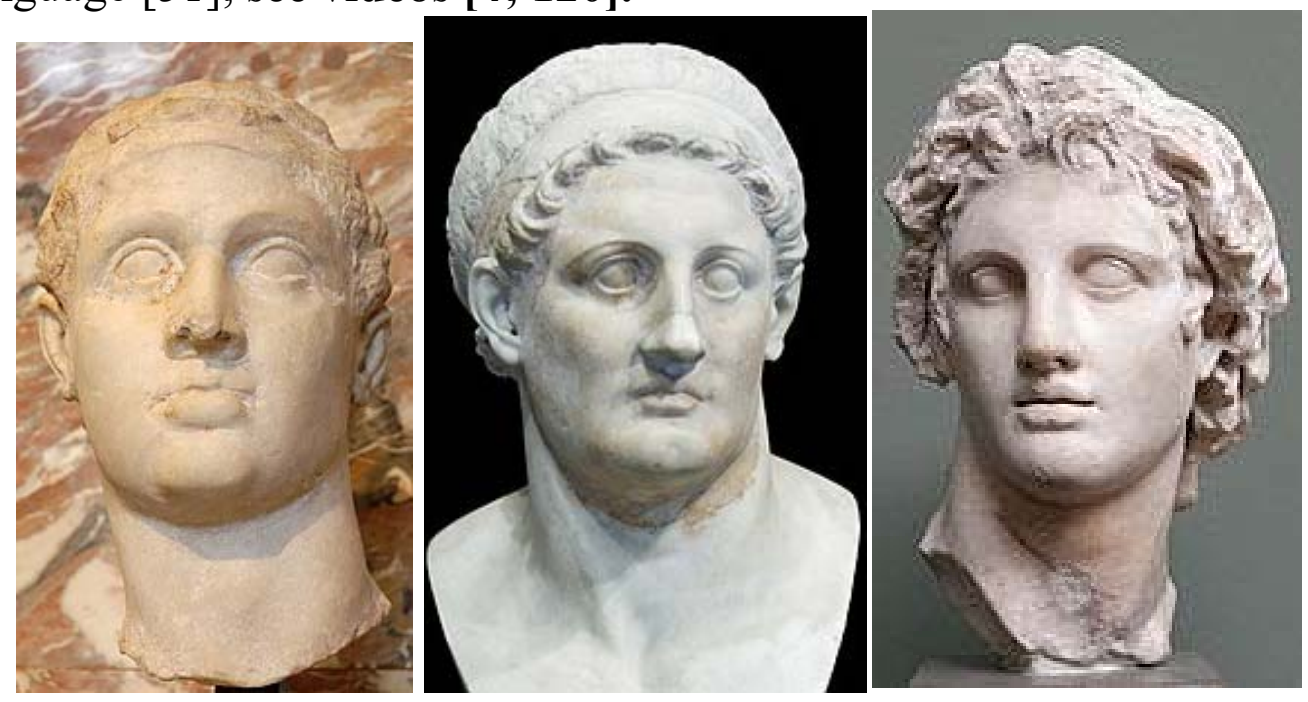

Fig. 6. Ptolemy II. Fig. 7. Bust of Ptolemy I Soter. Fig. 8. Alexander the Great. 
Cleopatra was clever and well-educated, but unlike Caesar and Augustus the nature of her intelligence remains elusive, and it is very hard to see how her mind worked or fairly assess her intellect [52], see video [73].

Cleopatra could speak various languages and served as the dominant ruler in all three of her co-regencies. Her romantic liaisons and military alliances with the Roman leaders Julius Caesar (Fig. 9) and Mark Antony (Fig. 10, see videos [84; 86; 25]), as well as her supposed exotic beauty and powers of seduction, earned her an enduring place in history and popular myth [57; 72], see video [51].

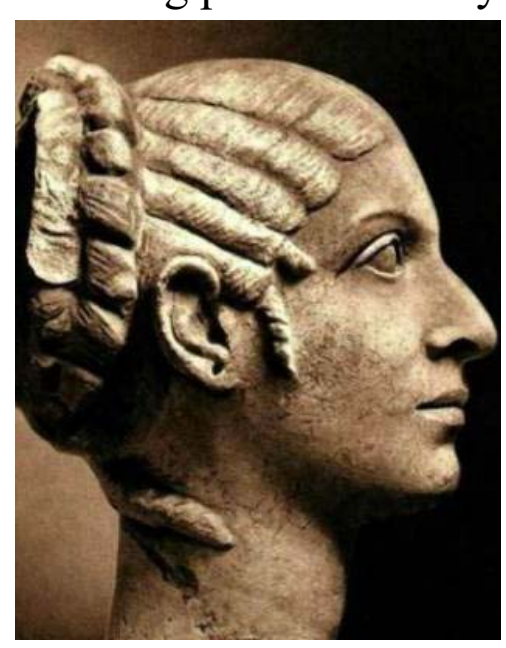

Fig. 9. Cleopatra.

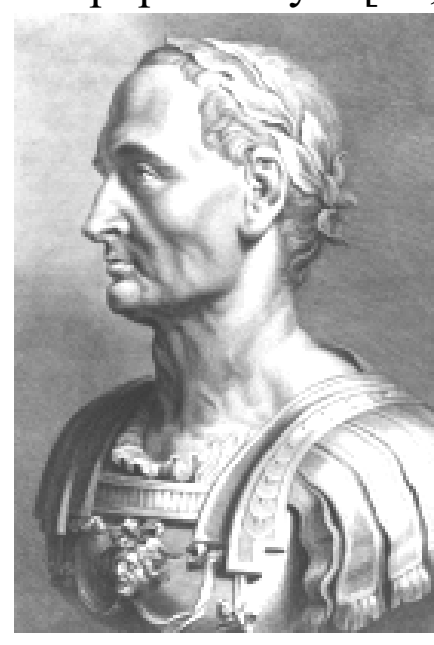

Fig. 10. Julius Caesar.

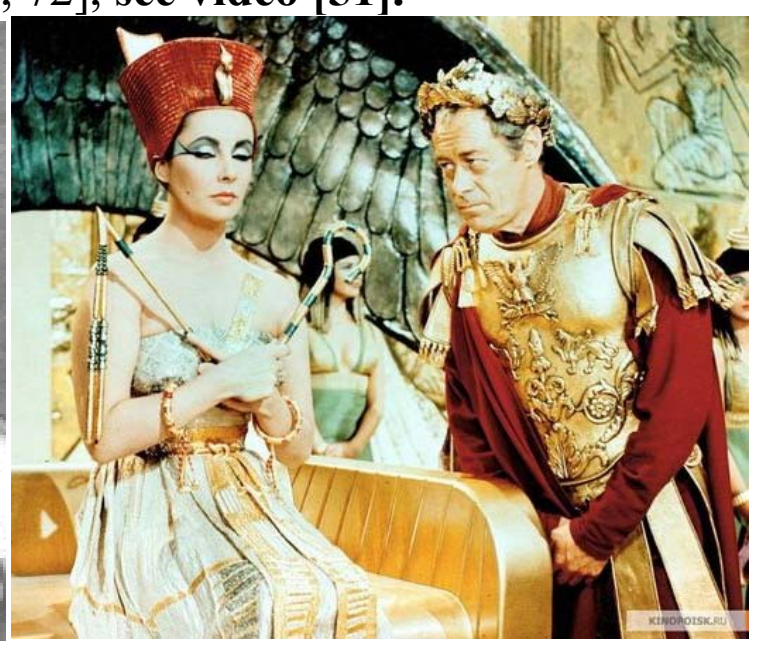

Fig. 11. Cleopatra (1963, USA).

Cleopatra (Fig. 9) believed herself to be a living goddess, and she often used clever stagecraft to woo potential allies and reinforce her divine status.A famous example of her flair for the dramatic came in 48 B.C., when Julius Caesar (Fig 10) arrived in Alexandria during her feud with her brother Ptolemy XIII. Knowing Ptolemy's forces would thwart her attempts to meet with the Roman general,
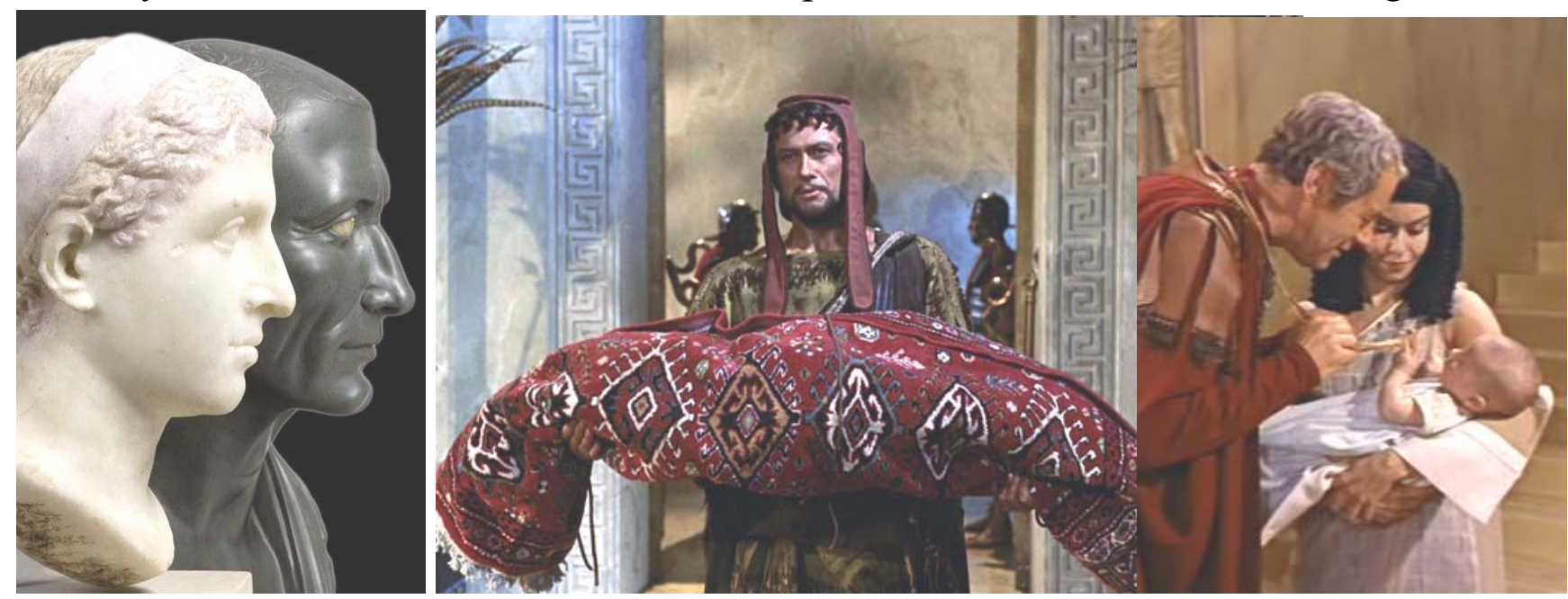

Fig. 12. Cleopatra and Caesar. Fig. 13. Cleopatra (1963) [14]. Fig. 14. Caesar and Caesarion. 
Cleopatra had herself wrapped in a carpet (Fig. 13, 43), see video [46; 63]) - some sources say it was a linen sack - and smuggled into his personal quarters. Caesar was dazzled by the sight of the young queen in her royal garb, and the two soon became allies and lovers [61], see the movie [80]. As Caesar was named a dictator and Cleopatra a goddess (Fig. 11; 12), the queen gave birth to his son (Fig. 14). Caesarion's birth encourages Cleopatra in her ideas of building a world empire (see the video $[30 ; 33])$.

Cleopatra later employed a similar bit of theater in her 41 B.C. encounter with Mark Antony. When summoned to meet the Roman Triumvir in Tarsus (Fig. 16), she

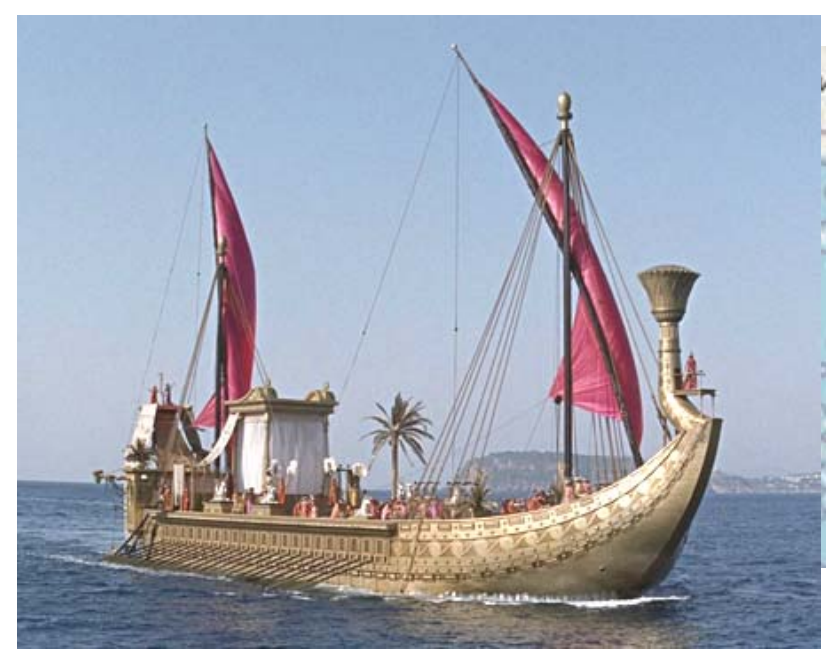

Fig. 15. Cleopatra's fabled Golden Barge.

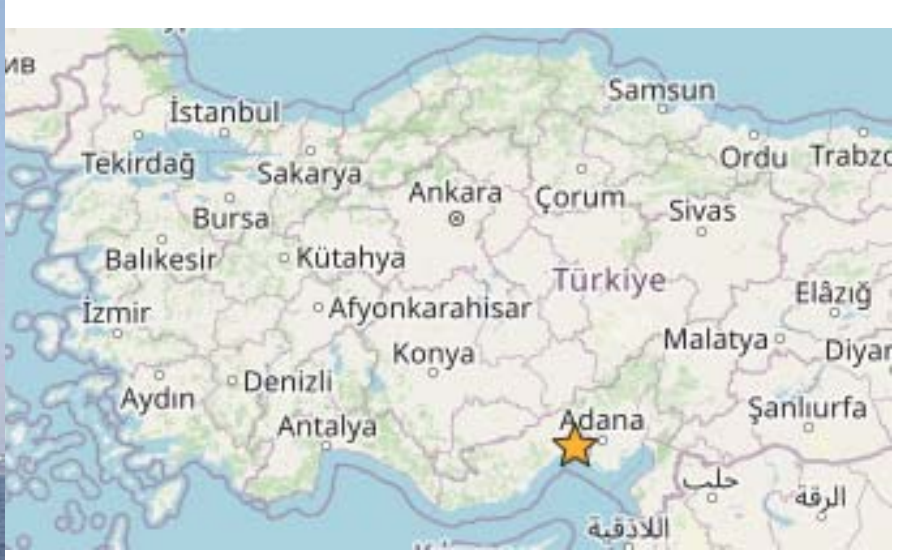

Fig. 16. Tarsus (Turky).

GPS coordinates: $\mathbf{3 6 . 9 1 3 2 0 2}, \mathbf{3 4 . 8 9 2 0 6 7}$

is said to have arrived on a golden barge adorned with purple sails and rowed by oars made of silver (Fig. 15). Cleopatra had been made up to look like the goddess Aphrodite (Fig. 18, 19, 20), and she sat beneath a gilded canopy while attendants dressed as cupids fanned her and burned sweet-smelling incense. Antony - who considered himself the

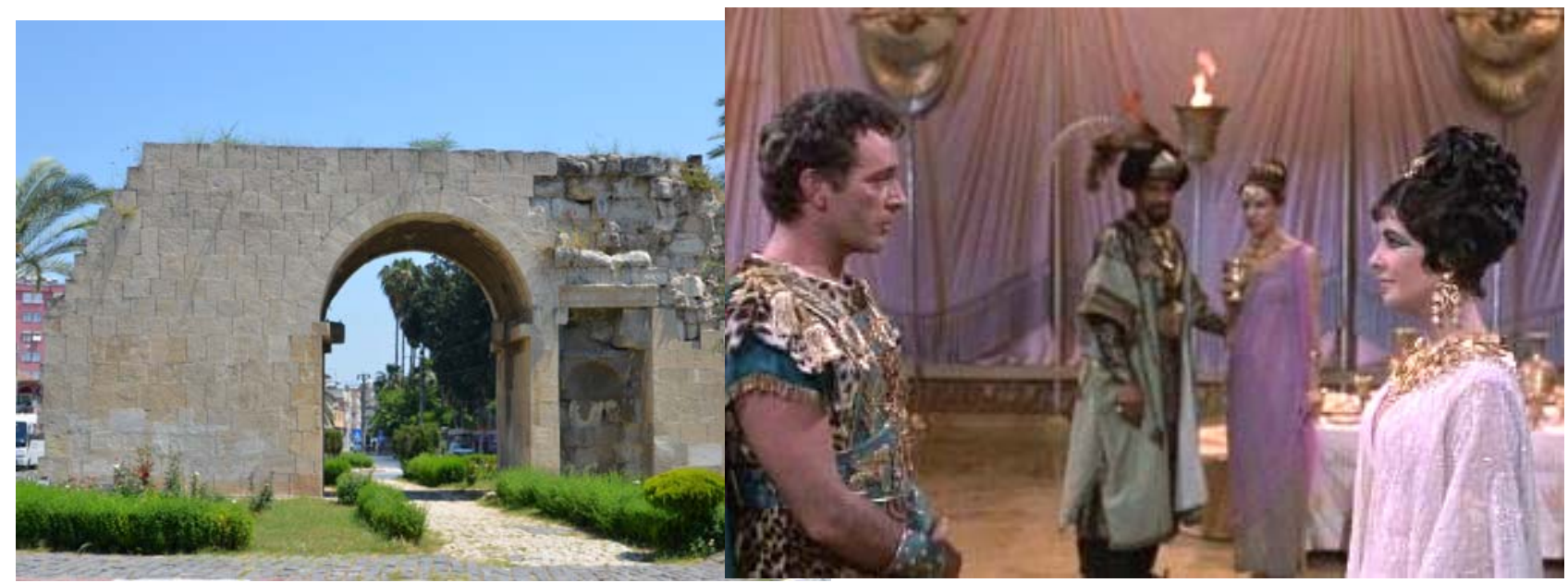

Fig. 17. Cleopatra's Gate in Tarsus.

Fig. 18. Antony (Richard Burton) and Cleopatra (Elizabeth Taylor). Meeting on the bardge (Cleopatra, 1963). 
embodiment of the Greek god Dionysus (Fig. 21) - was instantly enchanted [61].

The Parthian Empire located in modern-day Iraq posed a threat to Antony's eastern territory and he planned a military campaign to subdue them. But Antony needed money to put his plan into action and he looked to Cleopatra - ruler of Egypt and the richest woman in the world - to supply it. In $41 \mathrm{BC}$ he summoned Cleopatra to meet him in the city of Tarsus in modern-day Turkey [49]. (Fig. 17, 18).

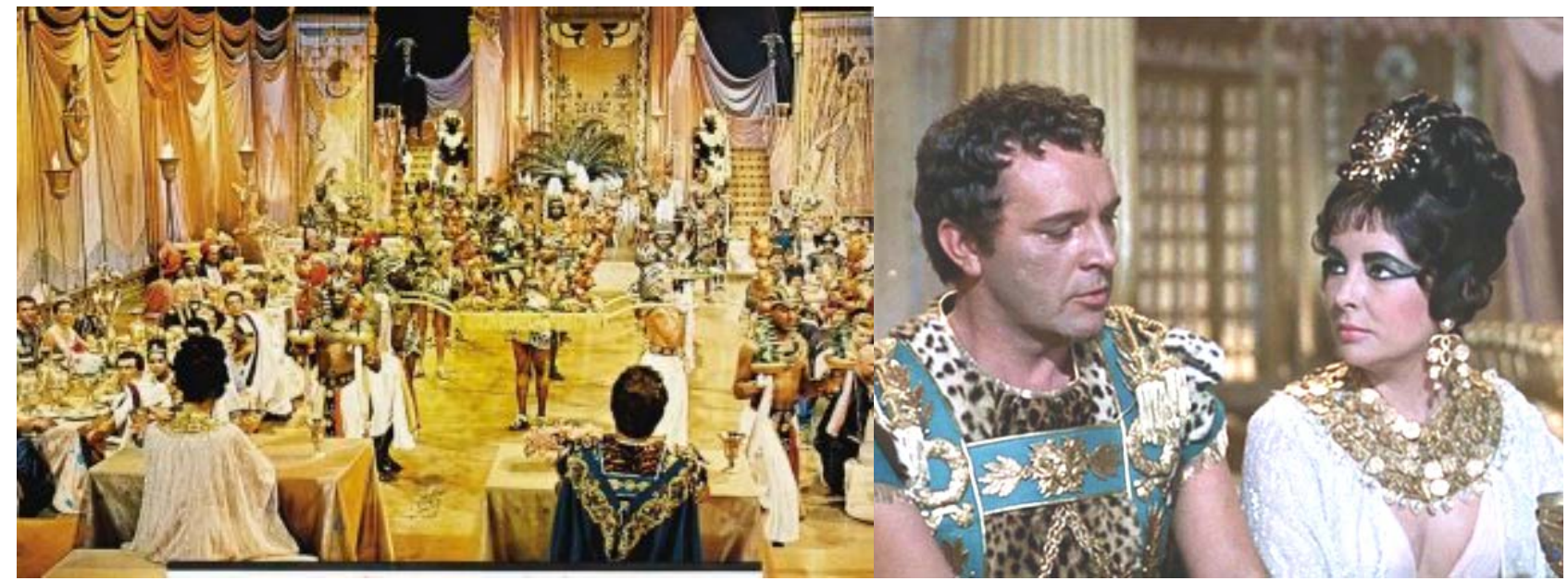

Fig. 19. Feast on the bardge (Cleopatra, 1963).

Fig. 20. Antony and Cleopatra on the feast.
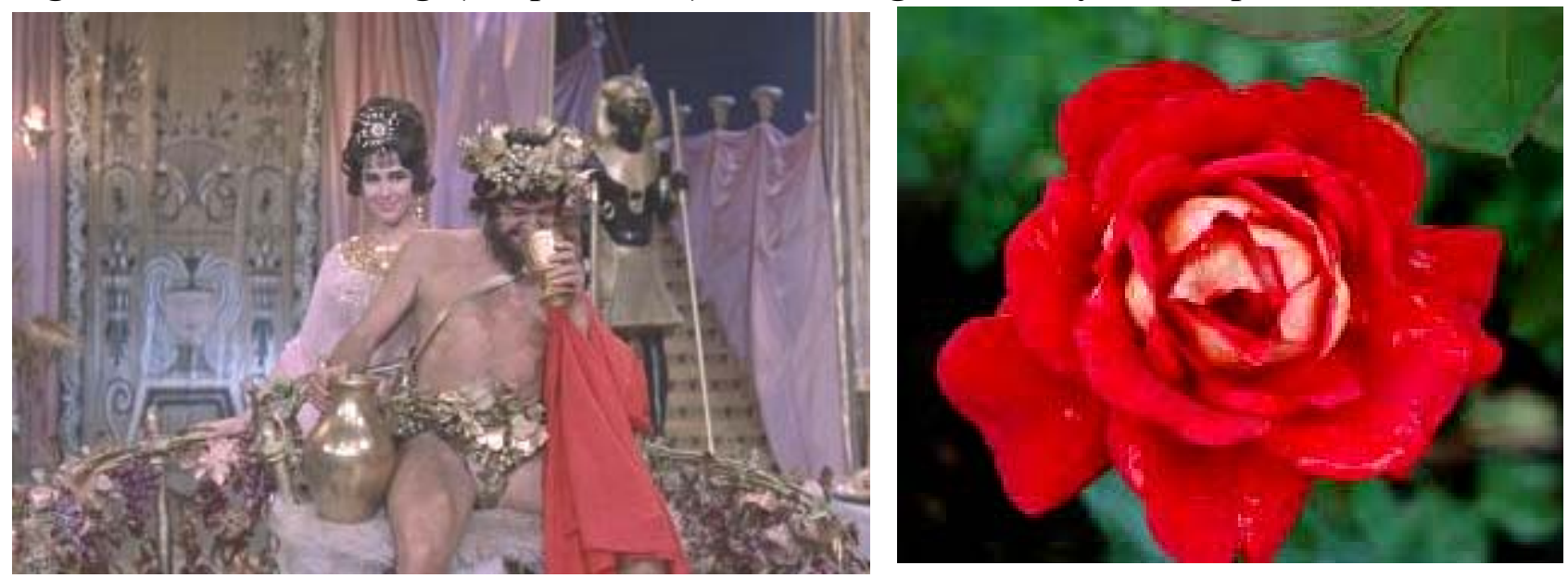

Fig. 21. Cleopatraas Afrodita and the Greek god Dionysus.

Fig > 22. Rosa Cleopatra (1994).

Tarsus is a city with a very long history, and numerous famous individuals have strolled down its streets. The first meeting of Mark Antony and Cleopatra (Fig. 18; 19; 20;21, see video [34]) is undoubtedly one of the most colourful episodes in the history of Tarsus. It is often said that it took place at one of the massive gates of the city. This particular gate is now called the Cleopatra's Gate (Fig. 17) at the memory of that event. Ancient Tarsus, the capital of the Roman province of Cilicia, was surrounded by two lines of fortifications [52].

[Antony was by Plutarch] "...carried away by her to Alexandria, there to keep 
holiday, like a boy, in play and diversion, squandering and fooling away in enjoyment that most costly of all valuables, time" [49].

Plutarch was a Greek historian who wrote a history of the life of Antony in the first century AD. We join his story as Cleopatra receives Antony's summons to join him:

"She had faith in her own attractions, which, having formerly recommended her to Caesar and the young Pompey, she did not doubt might prove yet more successful with Antony. Their acquaintance was with her when a girl, young, and ignorant of the world, but she was to meet Antony in the time of life when women's beauty is most splendid, and their intellects are in full maturity. She made great preparations for her journey, of money, gifts, and ornaments of value, such as so wealthy a kingdom might afford, but she brought with her her surest hopes in her own magic arts and charms.

...she came sailing up the river Cydnus in a barge with gilded stern and outspread sails of purple, while oars of silver beat time to the music of flutes and fifes and harps. She herself lay all along, under a canopy of cloth of gold, dressed as Venus in a picture, and beautiful young boys, like painted Cupids, stood on each side to fan her. Her maids were dressed like Sea Nymphs and Graces, some steering at the rudder, some working at the ropes.

...perfumes diffused themselves from the vessel to the shore, which was covered with multitudes, part following the galley up the river on either bank, part running out of the city to see the sight. The market place was quite emptied, and Antony at last was left alone sitting upon the tribunal; while the word went .through all the multitude, that Venus was come to feast with Bacchus for the common good of Asia [49].

And what did Cleopatra really look like? (Fig. 23). Cleopatra made real based on The Berlin Cleopatra (Fig. 5), a sculpture created around the time of her visits to Rome in 46-44 BC. Her makeup look is based on the green/blue malachite paste for

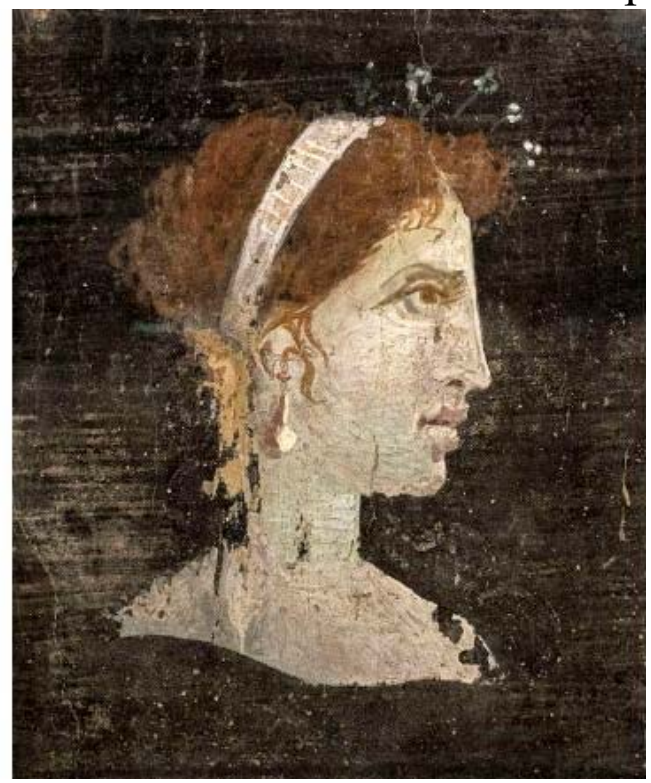
eyeshadow, red oche lipstick and rouge, and black khol for eyeliner and mascara [76].

Egyptologist Robert Bianchi says, for Cleopatra "there is nothing that approaches the Western concept of a portrait in either ancient Egyptian or ancient Greek art." But there are some potential leads. Among the most promising are coins minted during her reign - portrayals that are far from Hollywood's glamorous visions.

Fig. 23. A likely posthumously-painted portrait of Cleopatra, from Roman Herculaneum, Italy, dated to the 1st century AD.

No two coins are quite alike, but in many, the most prominent features are an 
aquiline nose and a jutting chin. She wears her curly hair not in bangs but in the popular melon style of the time, tied in a bun at the base of her skull [53], Fig. 24.

On some of the coins, her nose is seen to be less hooked, her cheeks full and her chin small. On coins issued by others, such as Mark Antony, her nose hooks dramatically, her forehead slopes broadly, her chin is pointy and her entire face is percieved as more masculine [54], Fig. 25, see the videos [133; 134].

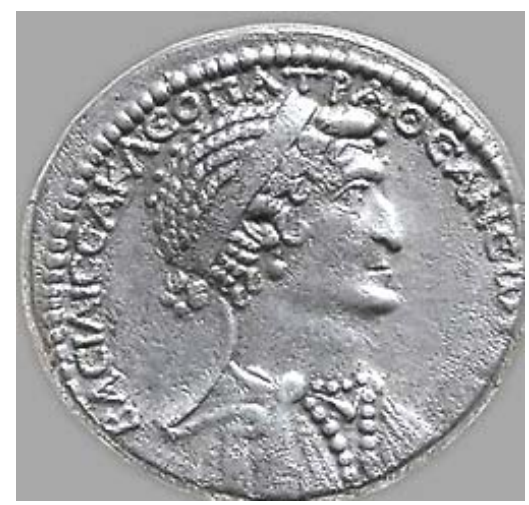

Fig. 24. A coin from Antony and Cleopatra's alliance, dated to 37-33 B.C.

The obsession with Cleopatra's looks started in literature and drama. In Shakespeare's play Antony and Cleopatra, the queen's portrait was stated as:

Age cannot wither her, nor custom stale Her infinite variety: other women cloy

The appetites they feed: but she makes hungry

Where most she satisfies; for vilest things

Become themselves in her: that the holy priests

Bless her when she is riggish [wanton]"

\section{Shakespeare, Antony and Cleopatra (II.ii)}

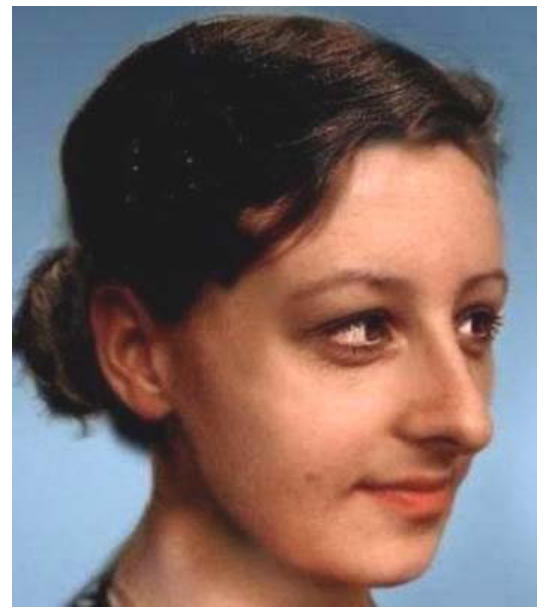

Fig. 27. Modern Cleopatra by Sally-Ann Ashton.

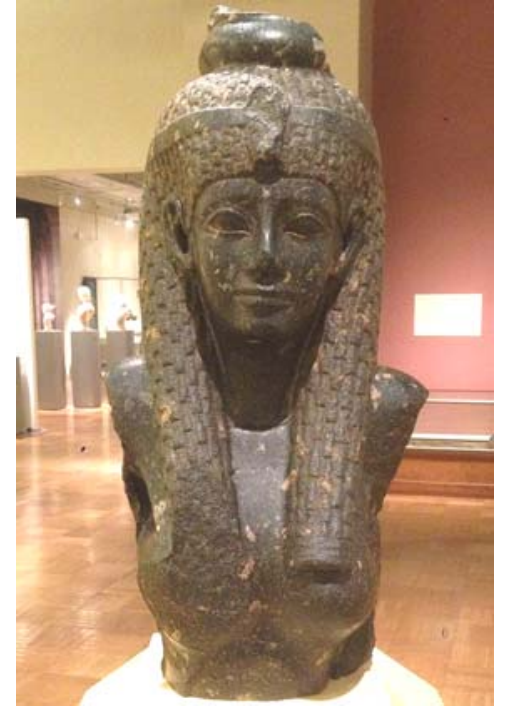

Fig. 28. Bust of Cleopatra.

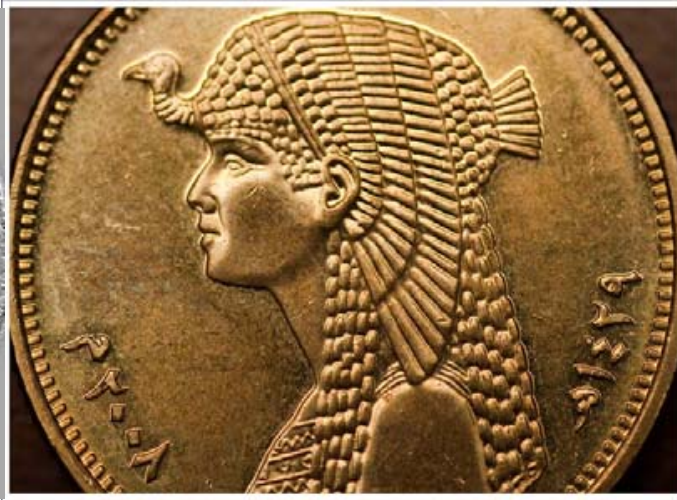

Fig. 25. Cleopatra Coin Depiction

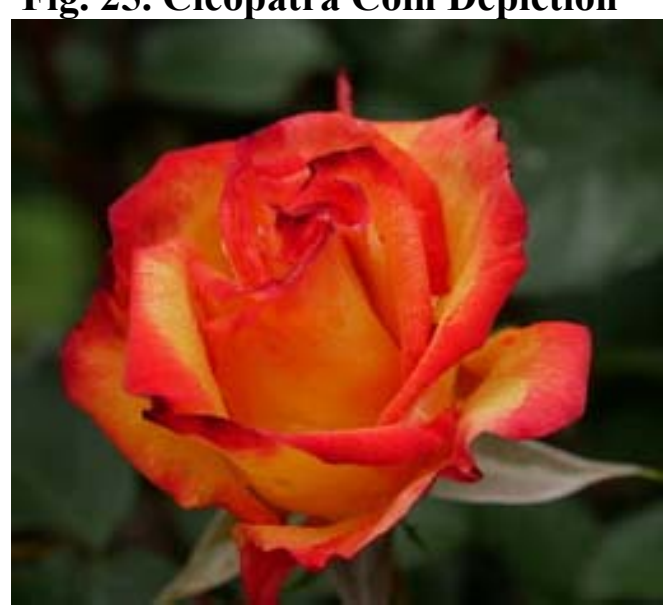

Fig. 26. The Rose Cleopatra.

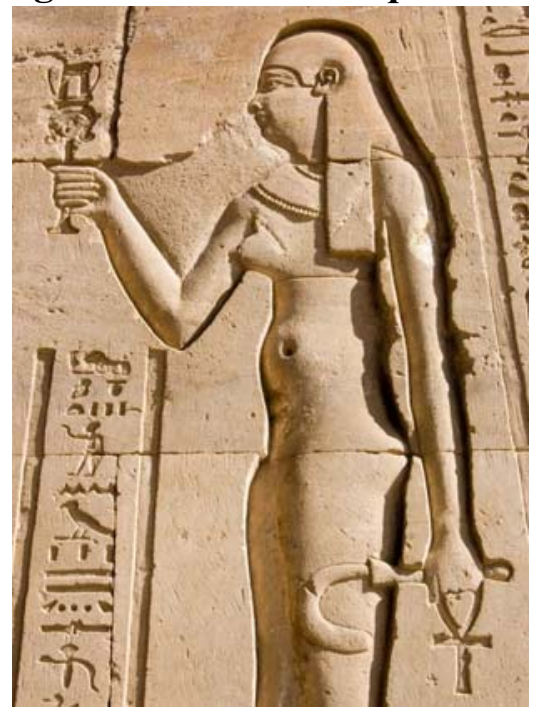

Fig. 29. Cleopatra Statue. 
A second portrayal came from H. Rider Haggard's novel Cleopatra (1889) who had a more direct description of the queen, who is a 'Thing of Flame':

"Then I looked upon...that face which seduced Caesar... I looked upon the flawless Grecian features, the rounded chin, the full, rich lips, the chiselled nostrils, and the ears fashioned like delicate shells. I saw the forehead, low, broad, and lovely, the crisped, dark hair falling in heavy waves that sparkled in the sun, the arched eyebrows, and the long, bent lashes. There before me was the grandeur of her Imperial shape. There burnt the wonderful eyes, hued like the Cyprian violet" [17].

An Egyptologist from Cambridge Sally Ann Ashton, analyzed the genealogy of Cleopatra, her profile on ancient coins, as well as sculptural images and reproductions of the temple decorations in Dandara (located on the west bank of the Nile). The Egyptologist came to the conclusion that Cleopatra's nose was too large, her lips were thin, and her chin was sharp. The skin color of the legendary woman was dark. Besides, her body did not meet the beauty standards of our time. With a height of $4.9 \mathrm{ft}$, she was obviously overweight [15]. Fig. 27, see the videos [76; 77].

In Hollywood, Cleopatra has been played by an array of stunning actresses. Elizabeth Taylor (Fig. 30), who was put under the "gaze" as the "Queen of the Nile" in the best-known film version of the ruler's story, Cleopatra (1963, USA), is a mainstay on short lists of moviedom's most attractive leading ladies (see the movie [31]. Cleopatra is a silent film created in 1912 by Helen Gardner (Fig. 31) and the Helen Gardner Picture Players. The film, in which Gardner stars in the title role, was based
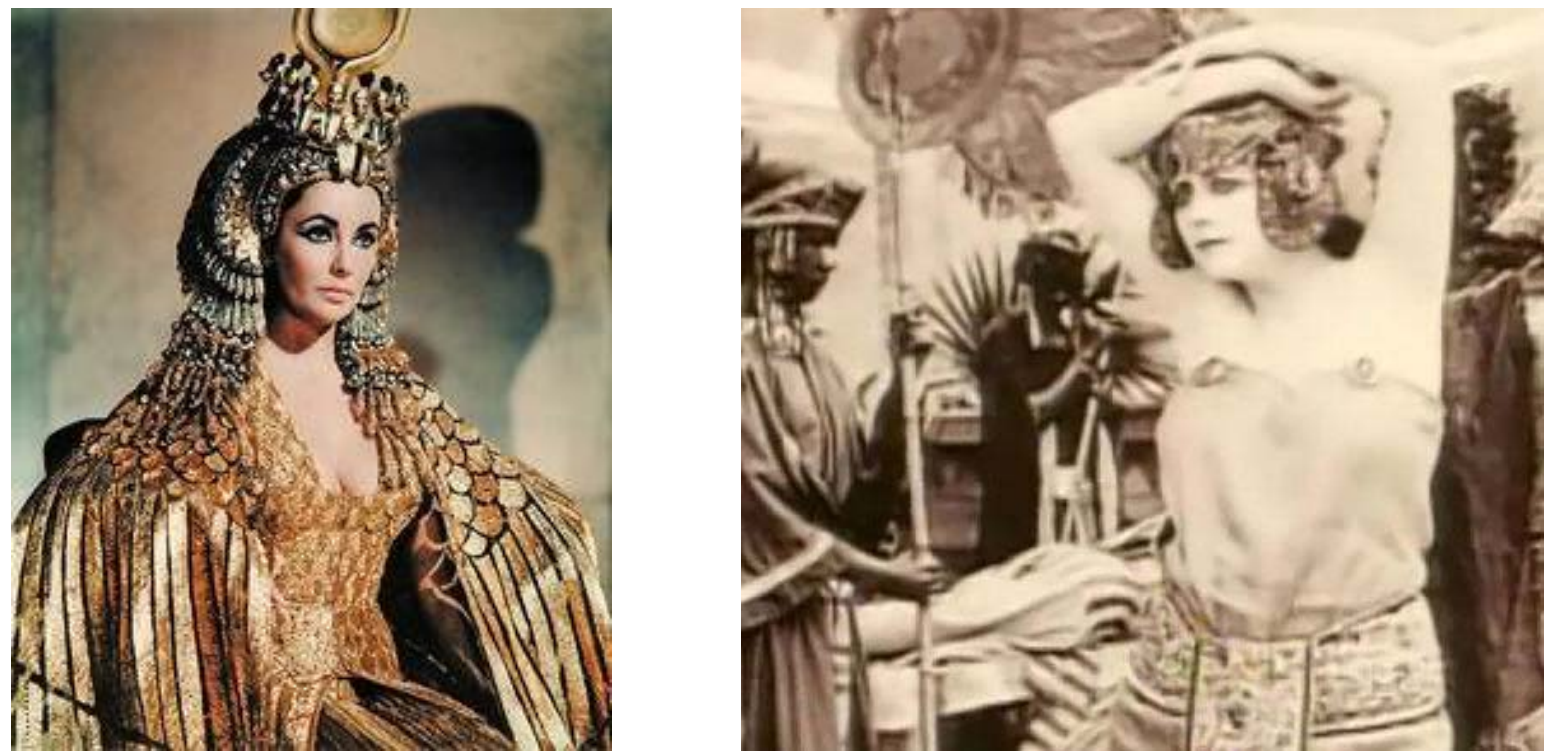

Fig. 30. Elizabeth Taylor as Cleopatra (1963). Fig. 31. Helen Gardner as Cleopatra (1912). 
on a play written by Victorien Sardou (see the movie [27]).

One of cinema's first sex symbols, Theda Bara (Fig. 32), invested her Cleopatra with dark sensuality in the lost silent classic Cleopatra (1917), (see video [126]). Before the Production Code reined in sexual suggestiveness, a scantily clad Claudette Colbert (Fig. 33, see the movie [28]) caused a sensation in Cecil B. DeMille's
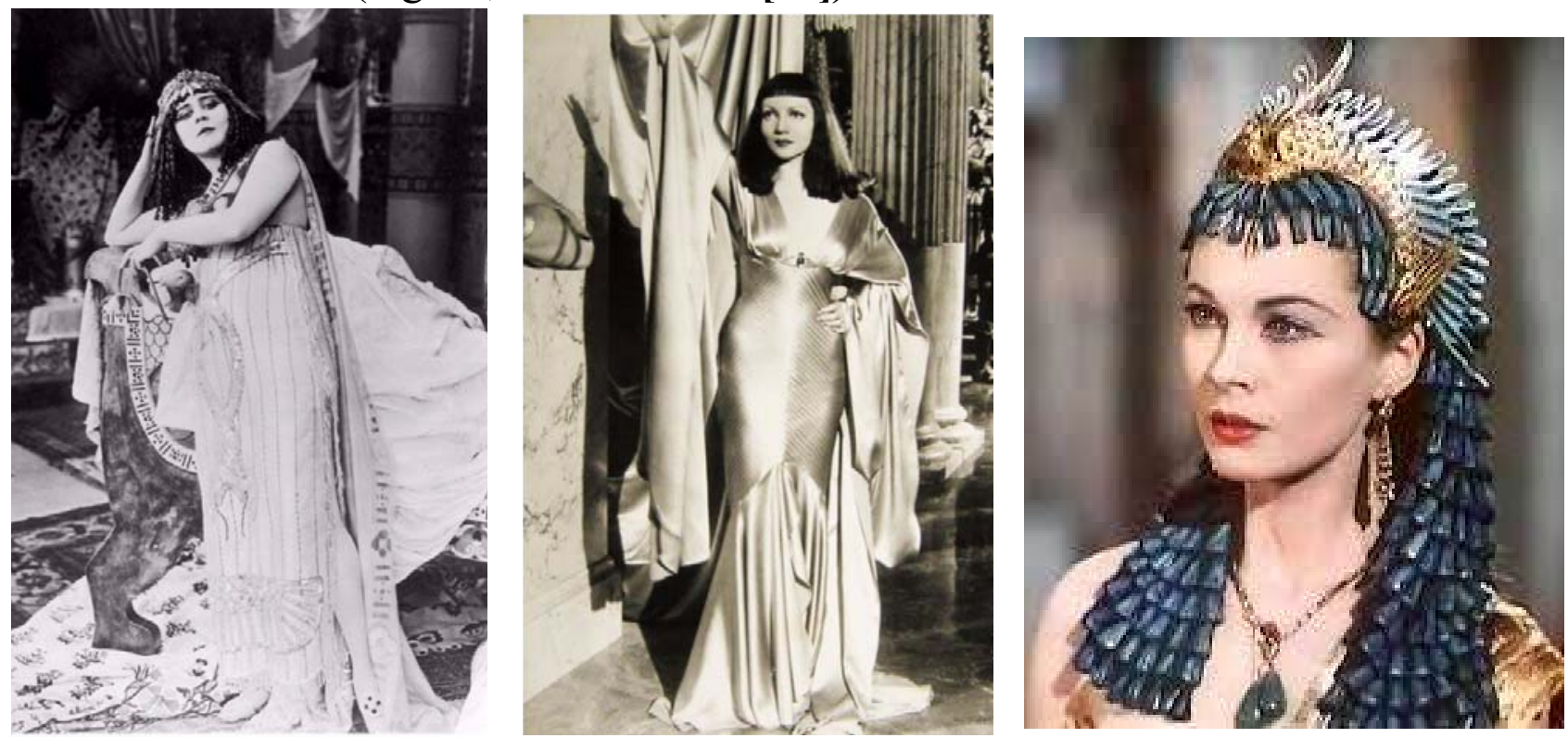

Fig. 32. Theda Bara, 1917. Fig. 33. Claudette Colbert, 1934. Fig. 34. Vivian Leigh, 1945. epic Cleopatra (1934); Vivian Leigh (Fig. 34) was the beguiling queen in Caesar and Cleopatra (1945) (see the film [29]) [131] like Elena Koreneva as Cleopatra (Fig. 35) in Caesar and Cleopatra (1979) by B. Show (see the movies [112; 113]).

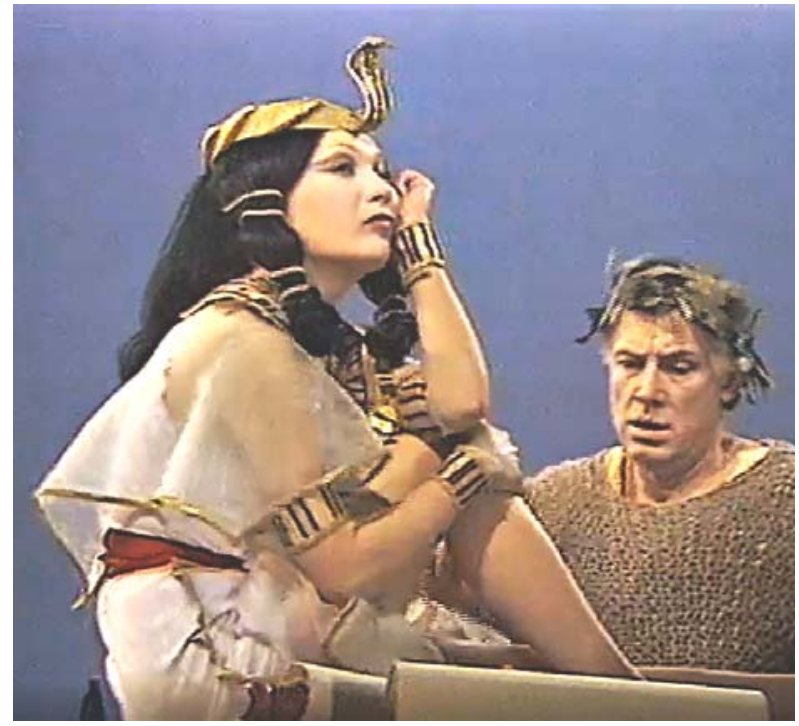

Fig. 35. Elena Koreneva as Cleopatra, 1979.

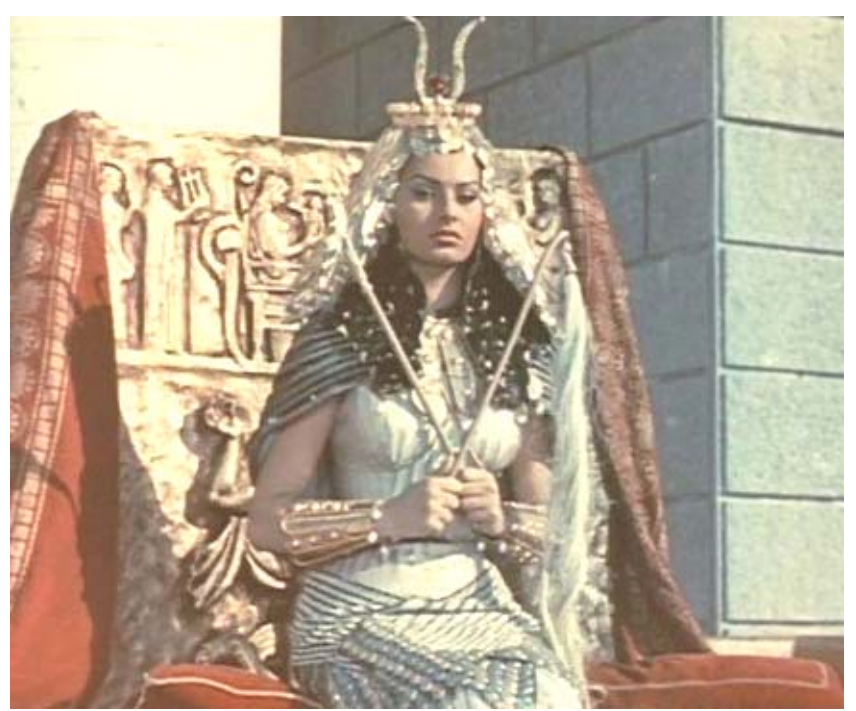

Fig. 36. Sophia Loren as Cleopatra, 1954.

Sophia Loren in Two nights with Cleopatra (1954, Italy), Fig. 36, see video [62];

Monica Bellucci in Asterix \& Obelix: Mission Cleopatre (2002), Fig. 37, see videos

[11; 12]; Leonor Varela in Cleopatra (1999) (see the movie [36], Fig. 38). 

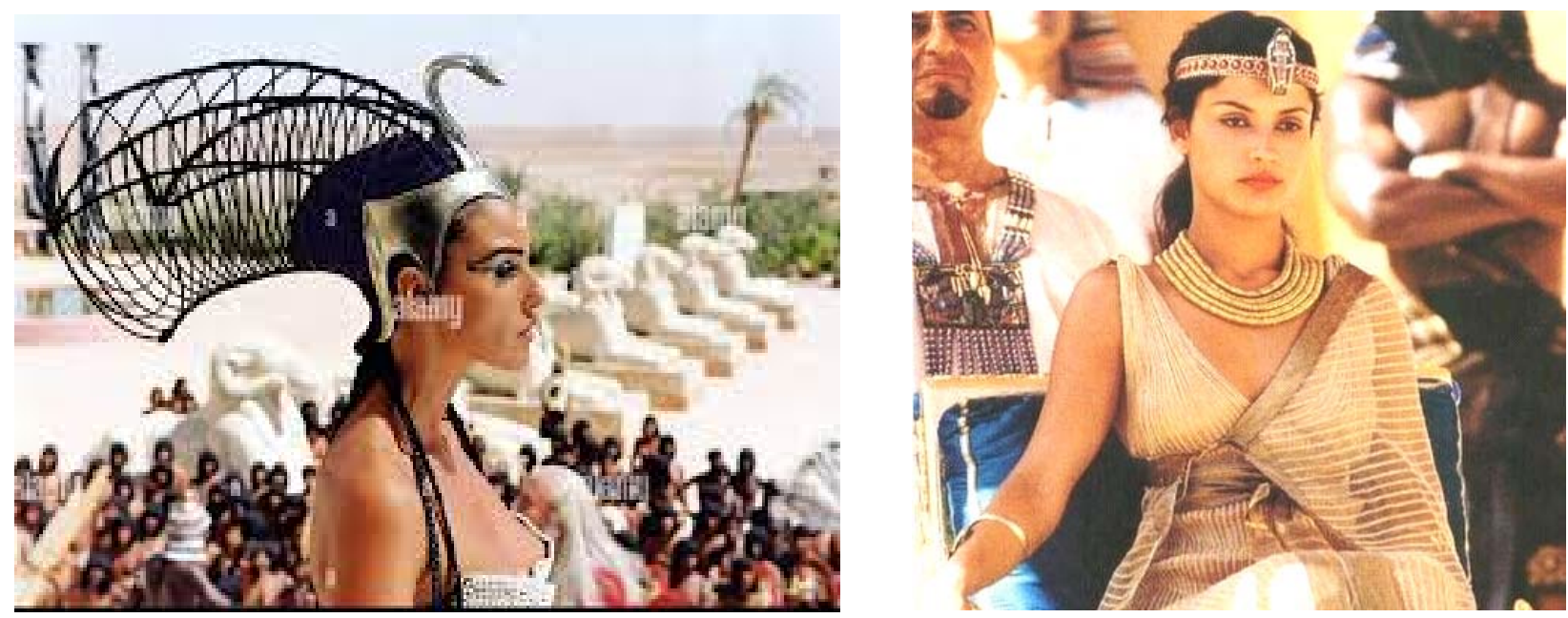

Fig. 37. Monica Bellucci as Cleopatra (2002). Fig. 38. Leonor Varela as Cleopatra (1999).

It's 20 years since a fine book by Lucy Hughes-Hallett [72] undertook to disentangle the last and most resourceful of the Ptolemys from those myths which have masked her as an eastern whore (Boccaccio, 1313-1375); a lustful sinner (Dante (Fig. 40); an avaricious nymphomaniac (Cassius Dio); and - even further from the mark a "silly little girl" (B. Shaw). Hughes-Hallett's work has now spawned a worthy successor. Ideally, as Stacy Schiff observes in her magnificent re-creation of both an extraordinary woman [37]., and her times, our sense of Cleopatra would be heightened by her dramatic appearance as the doomed heroine of a sumptuous opera (Massne).

Cleopatra was well known for her stunning beauty, and her seductive relationships with the Roman dictator Julius Caesar, and his general, Marc Antony.

The Inferno, the first part of Dante's Divine Comedy (Italian poet and scholar Dante Alighieri (Fig. 39) is best known for his masterpiece La Commedia (known in

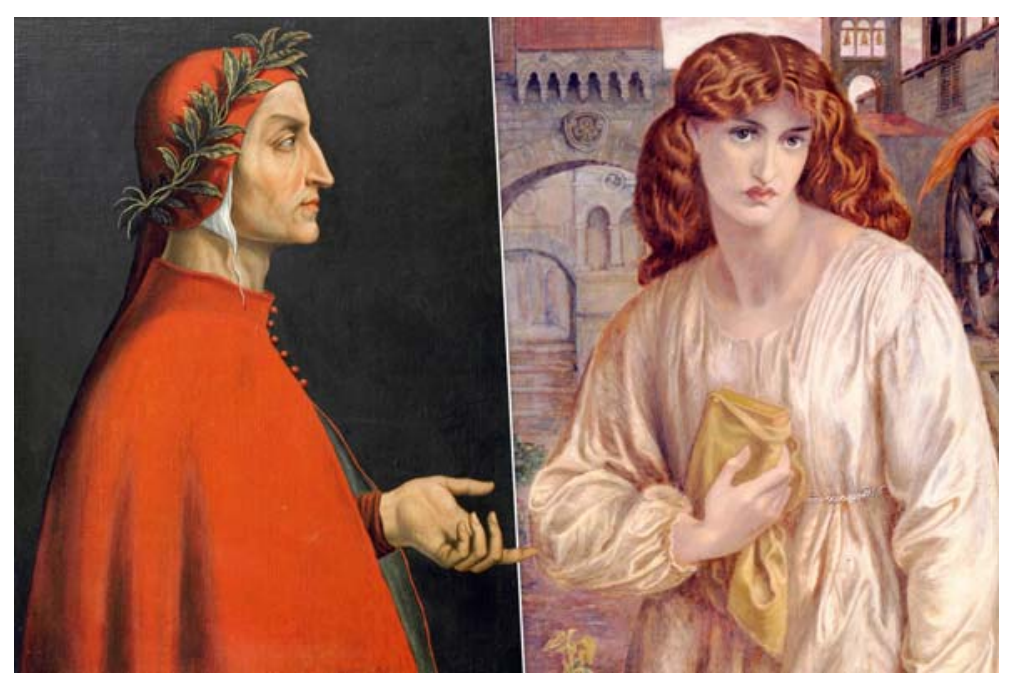

English as The Divine Comedy), which is universally considered one of world literature's greatest poems) that inspired describes the poet's vision of Hell. The story begins with the narrator (who is the poet himself) being lost in a dark wood where he is Fig. 39. Dante Alighieri and Beatrice. attacked by three beasts which he 
cannot escape. He is rescued by the Roman poet Virgil who is and sent by Beatrice (Dante's ideal woman) (Fig. 39). Together, they begin the journey into the underworld or the 9 Circles of Hell [90], see videos [67; 138], Fig. 41.

In "The Inferno" Dante placed the soul of Cleopatra, along with her lover Marc Antony (Fig. 42), in the second circle for her sins of lust [108], see video [16].

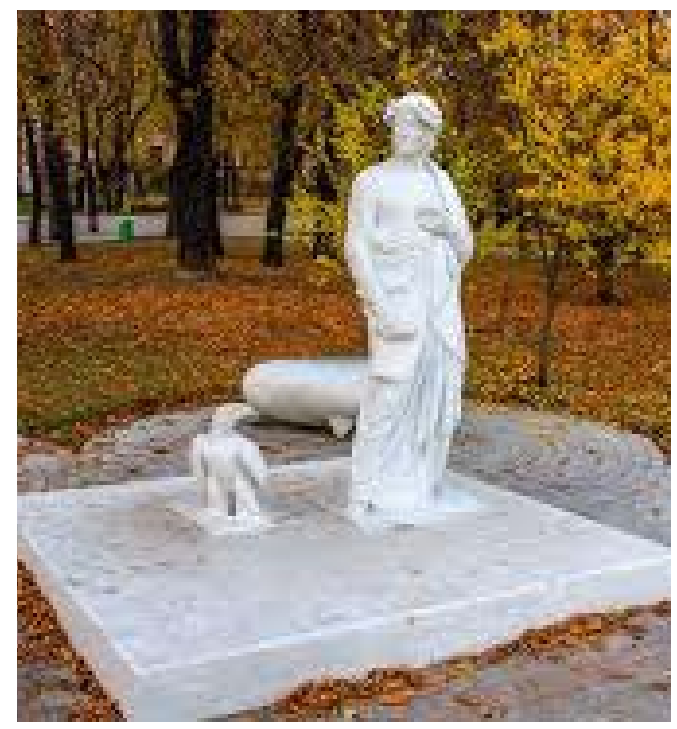

Fig. 40. The Dante Alighieri sculpture in Saint Vladimir Hill park in Kyiv by Luciano Massari (2015).

Cirkle 1. Limbo: Where those who never knew Christ exist. Dante encounters Ovid, Homer, Socrates, Aristotle, Julius Caesar (Fig. 43), and more here. Cirkle 2. Lust: Selfexplanatory. Dante encounters Achilles, Paris, Tristan, Cleopatra, and Dido, Mark Antony among others... [22].

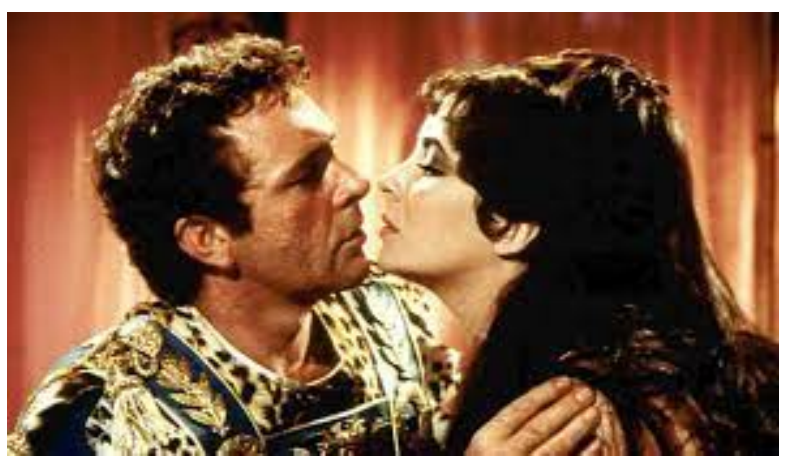

Fig. 43. Cleopatra Before Caesar (1866) by Jean-Léon Gérôme.

Fig. 42. Antony and Cleopatra (Cleopatra, 1963).

In Dante's Hell, a person is judged by his own standards, that is, by the standards 
of the society in which he lived. For example, in classical times, suicide wasn't considered a sin, but adultery was. Therefore, the spirit is judged by the ethics by which he or she lived and is condemned for adultery, not suicide. The second circle is the true beginning of Hell and is also where the true punishments of Hell begin, and Minos, the mythological king of Crete, sits in judgment of the damned souls.Circle II is the circle of carnal lust. The sinners are tossed and whirled by the winds, as in life they felt themselves - helpless in the tempests of passion. This canto also begins descriptions of the circles devoted to the sins of incontinence: the sins of the appetite, the sins of self-indulgence, and the sins of passion.Among those whom Dante sees in Circle II are people such as Cleopatra, Dido, and Helen. Some of these women, besides being adulteresses, have also committed suicide [56].

While the Roman Republic collapsed, Cleopatra VII ruled Egypt as the most powerful woman in the world. Nearly 1400 years later, Giovanni Boccaccio (Italian poet and scholar, best remembered as the author of the earthy tales in the Decameron) wrote De Mulieribus Claris (1361) to honor women who overcame the limitations of their sex with a virilis animus, a "manly spirit." Cleopatra was a puzzle to Boccaccio: while she undeniably displayed the "manly" characteristics of intelligence and bravery, Boccaccio's Roman sources portrayed her as an uncontrollable corrupting influence [2], (Fig. 44, 45).
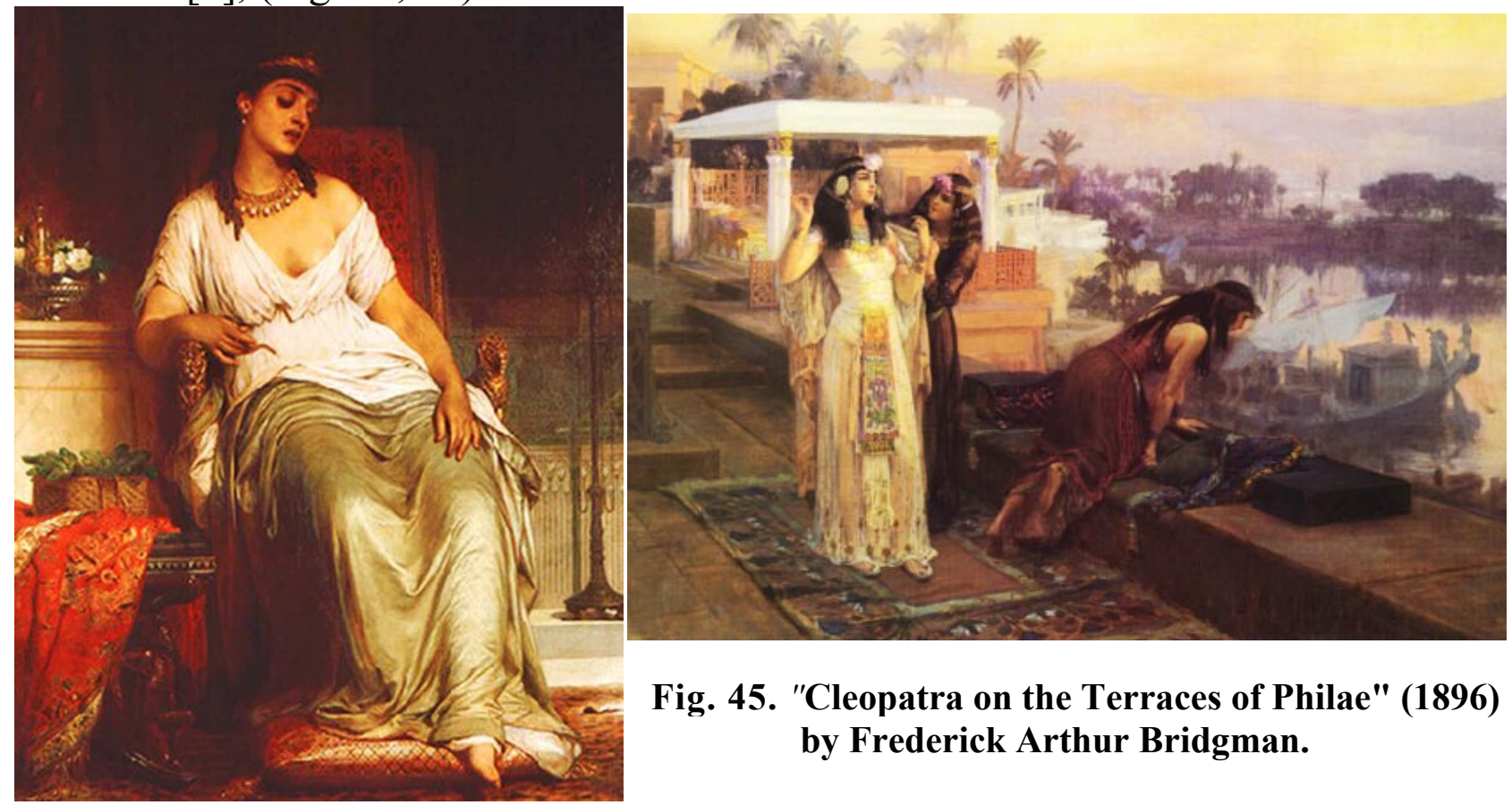

Fig. 45. "Cleopatra on the Terraces of Philae" (1896) by Frederick Arthur Bridgman.

Fig. 44. "Cleopatra" (1876) by Francis Bernard Dicksee. 
While artist Bridgman (1847-1928) specialized in scenes from daily life in North Africa especially its women - "Cleopatra on the Terraces of Philae", 1896 (Fig. 45) is one of several imaginary historical scenes set in ancient Egypt. Cleopatra prepares her departure by boat from the idyllic island of Philae, now best known for its ruins of the Kiosk of Trajan, here depicted in the far left background - which was not actually built until a century after Cleopatra's reign [3].

The episode represented in painting The Banquet of Cleopatra by Giambattista Tiepolo (Fig. 46,47) is drawn from the Roman historian Pliny's Historia naturalis (Natural History). Here Pliny recounted the tale of a famous contest between the Egyptian and Roman rulers, where by Cleopatra wagered that she could stage a feast more lavish than the legendary excesses of Mark Antony. Tiepolo's painting shows the dramatic moment at the end of Cleopatra's

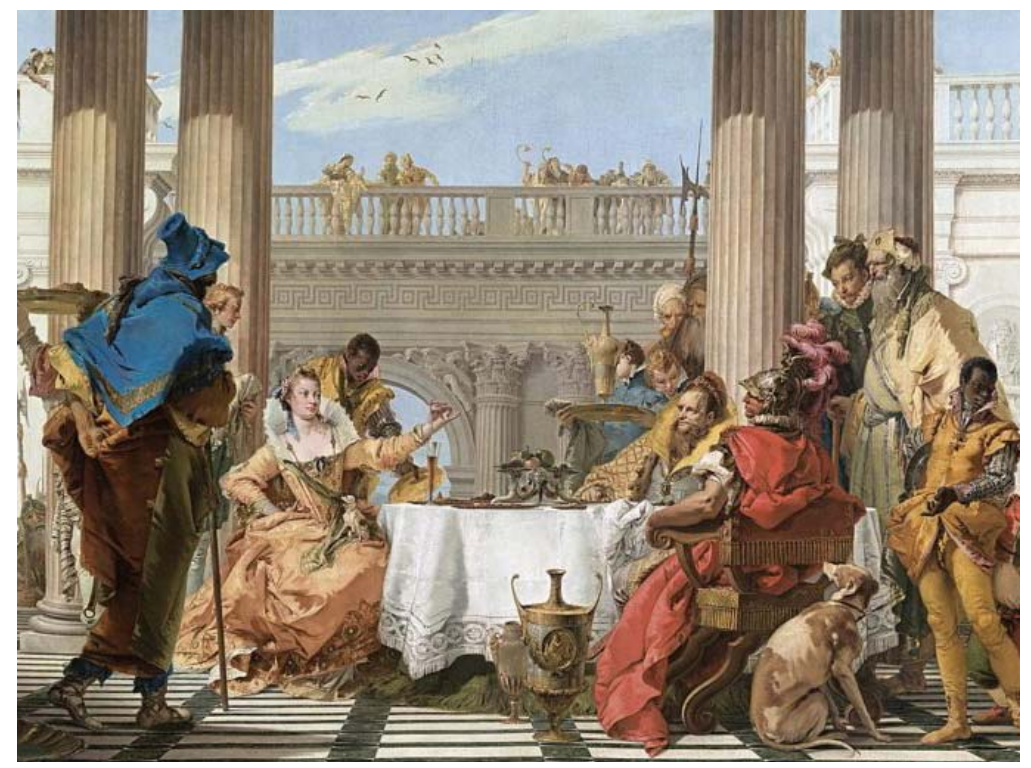

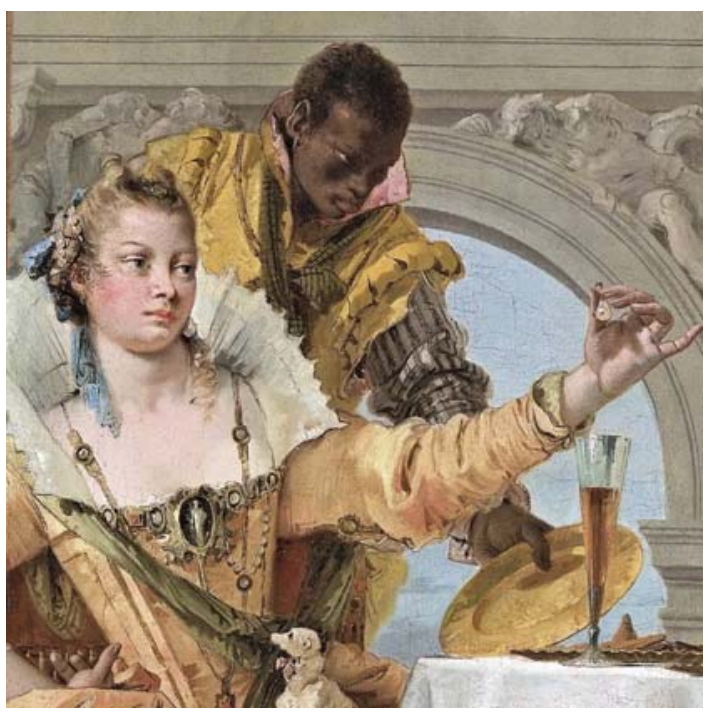

Fig. 47. A fragment of the painting.

Fig. 46. The Banquet of Cleopatra (1743-1744) by Giambattista Tiepolo.

sumptuous repast when, faced with a still scornful Mark Antony, she wins the wager by using her trump card. Removing one of a pair of priceless pearls that she wears as earrings, Cleopatra dissolves the pearl in a glass of vinegar and drinks it an extravagance that causes Mark Antony to lose his bet [70].

The famous story of Cleopatra's pearls is told by Pliny the Elder in his Natural History (9.119-21): "The last of the Egyptian queens," he says, "owned the two largest pearls of all time, left to her by oriental kings. When Antony was stuffing himself daily with rare foods, she proudly and impertinently, like the royal harlot that she was, sneered at his attempts at luxury and extravagance. When he asked her what could be added in the way of sumptuousness she replied that she would use up $10,000,000$ sesterces [ $\$ 500,000$ on the gold standard] at one dinner. Antony was 
eager to learn about it but didn't think it could be done. So they made a bet, and on the next day when the bet was to be decided, she set before Antony a dinner that under other circumstances would have been a magnificent one but was an everyday affair for Antony. She did this so that the day should not be entirely wasted. Antony laughed at her and asked for the reckoning. But she said that this was merely a preliminary and assured him that the real banquet would use up the estimated sum and that she would consume the half-million dollar dinner all by herself. Then she ordered the dessert to be served. According to instructions, the servants placed but one dish before her, containing vinegar whose acidity and strength dissolves pearls into slush (tabes is Pliny's word). She was at the time wearing in her ears that remarkable and truly unique work of nature known as pearls. So while Antony was wondering what in the world she was going to do, she took one pearl from her ear, plunged it into the vinegar, and when it was dissolved, swallowed it. Lucius Plancus, who was refereeing the bet, put his hand on the other pearl as she was preparing to dissolve it in like manner and declared Antony the loser. This was a definite omen [of Antony's fate]...

The friendship of Antony and Cleopatra lasted from 41 to 31 B.C. It might be thought that the pearl episode took place at the very beginning of their acquaintance in 41 , for Athenaeus, quoting Socrates of Rhodes (who apparently lived in the time of Augustus), describes the elaborate banquets that Cleopatra gave Antony and his friends when they first met... One is almost tempted to conjecture that Cleopatra had just read, or had heard a reading of, Horace's poem, which was written about 33 B.C...

It will be noticed that the Cleopatra story is ten times as good, as far as the supposed value of the pearl is concerned. Horace wrote his poem about 33 B.C., within a few years of the time when Cleopatra was doing her pearling. But Horace's tale concerns a young man who probably anticipated her by a few years, though some have assumed that Aesopus imitated Cleopatra.

Are these stories true? It is unfortunate for this good story, that no acid the human stomach can endure is capable of dissolving a Pearl even after a long

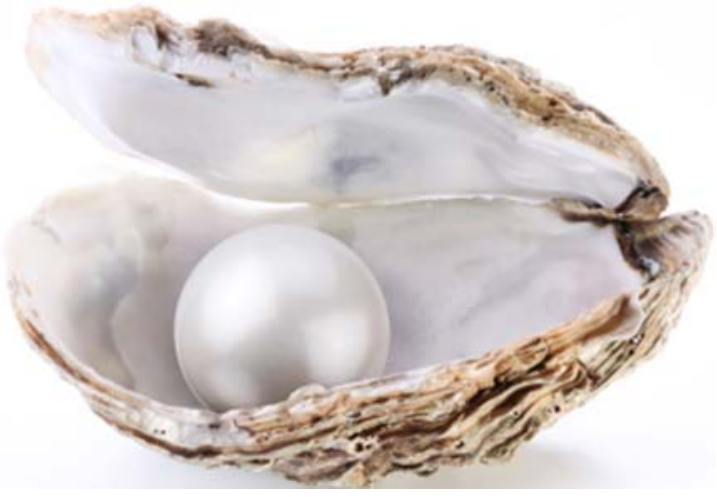

Fig. 48. A perle. maceration in it... No doubt the wily Egyptian swallowed her Pearl safe and sound, and in some more agreeable potation than vinegar, secure of its ultimate recovery uninjured; and invented the story of its complete and instantaneous dissolution...In any case, it is clear that the story about Cleopatra could not be true in its literal sense, though there is truth in it. Pearls don't dissolve instantly like pills.

Of what stuff is a pearl made? Carbonate of lime for the most part, 91.72 per cent to be exact, the same stuff that is in the oyster shell. But did the ancients know what pearls were made of and did they know the virtues of lime? The answer to both questions is "Yes." The word concha meant "oyster" or "shell" or "pearl" (Fig. 48).

The ancients added many substances to wine as antacids or preservatives or both... Gypsum (calcium sulphate) and lime were favorite wine preservatives in Africa... Cleopatra's pearl was that rich girl's substitute for plain lime powder.

Another famous story in which vinegar plays a part deserves passing mention here. Livy tells the tale, you recall, of Hannibal and his tribulations in crossing the Alps. Finally he came to a place where there was sheer rock and no road. So he had his soldiers gather firewood, build a huge fire on the rock, and then pour vinegar on it. This made the rock split and disintegrate...

The Cleopatra and Hannibal stories spring from the same source, the knowledge that limestone and marble, mother-of-pearl and pearls, produce carbonate of lime, and that they can be 
dissolved by vinegar, especially if they are first crushed [129].

With this goes the story that, when that queen who had won on this important issue was captured, the second of this pair of pearls was cut in two pieces, so that half a helping of the jewel might be in each of the ears of Venus in the Pantheon at Rome."

These days natural pearls appear in only rare vintage pieces. Take $L a$ Peregrina, a 51-carat pearl discovered in the 16th century that passed through the Spanish and French crowns before Richard Burton bought it for Elizabeth Taylor in 1969 at Sotheby's auction for $\$ 37,000$. Then, he gave the pearl to Elizabeth Taylor as a Valentine's gift (Fig. 49, 50). In 2011, the jewel fetched a record $\$ 11.8$ million at Christie's.
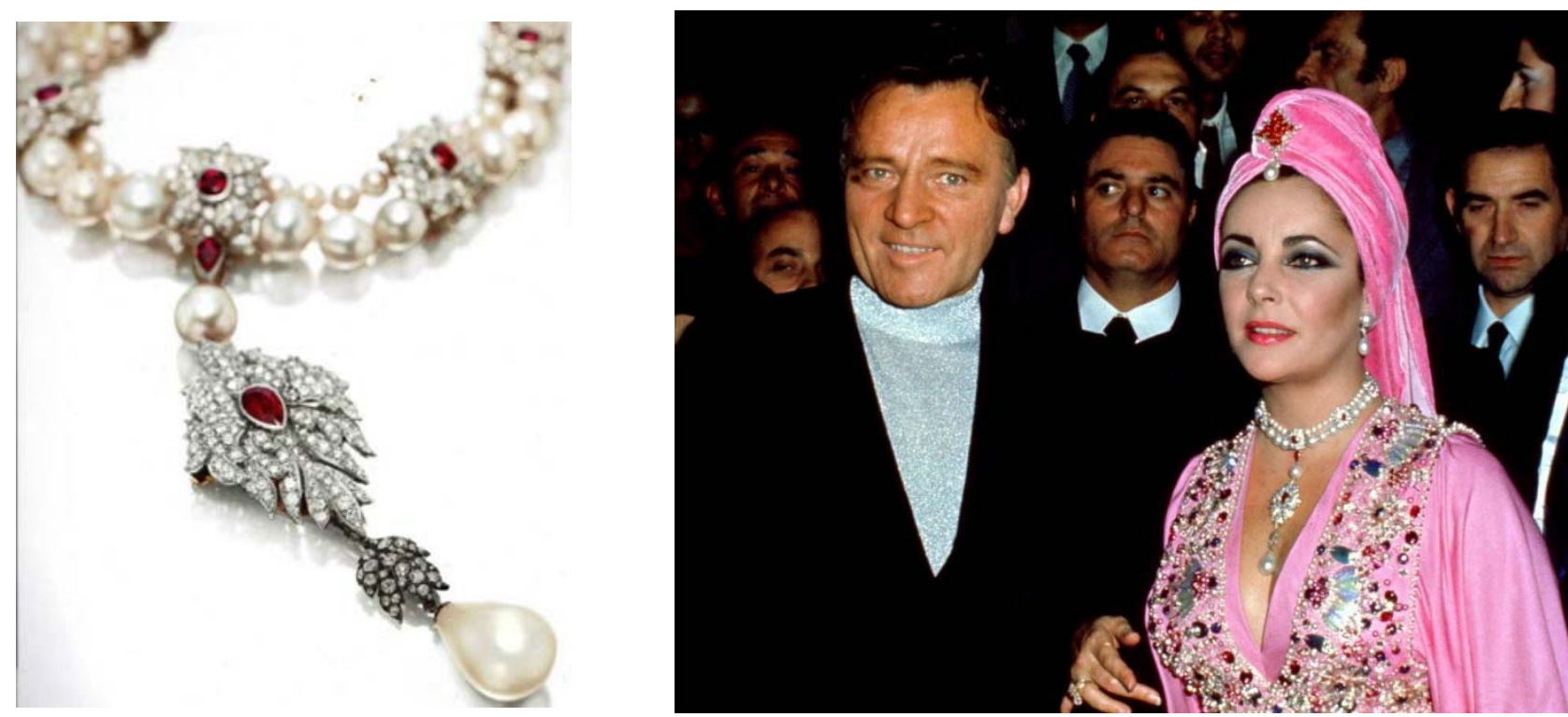

Fig. 49. La Peregrina, a 51-carat pearl.

Fig. 50. Richard Burton and Elizabeth Taylor.

And now we can remember comic operetta "Die Perlen der Cleopatra" by Oscar Straus see video [117] Under the baton of Artistic Director Barrie Kosky, the piece was revived at the Komische Oper in December 2016, almost 90 years after its initial run. The libretto from "The Pearls of Cleopatra" is easily explained: the Nile is drying out, the Romans are at the gates to the city and the locals are growing restless. The eccentric Egyptian queen, played by the grand Dagmar Manzel, is also suffering from a lack of manpower and has to work quickly to get out of this mess. There's plenty of the famed Berlin attitude, parodies of operas such as Aida and saucy dance scenes. Oscar Straus' operetta actually saw its premiere in Vienna in 1923, but traveled a year later to the Komische Oper in Berlin, where it was a massive success [122] (Fig. 51, 52). 

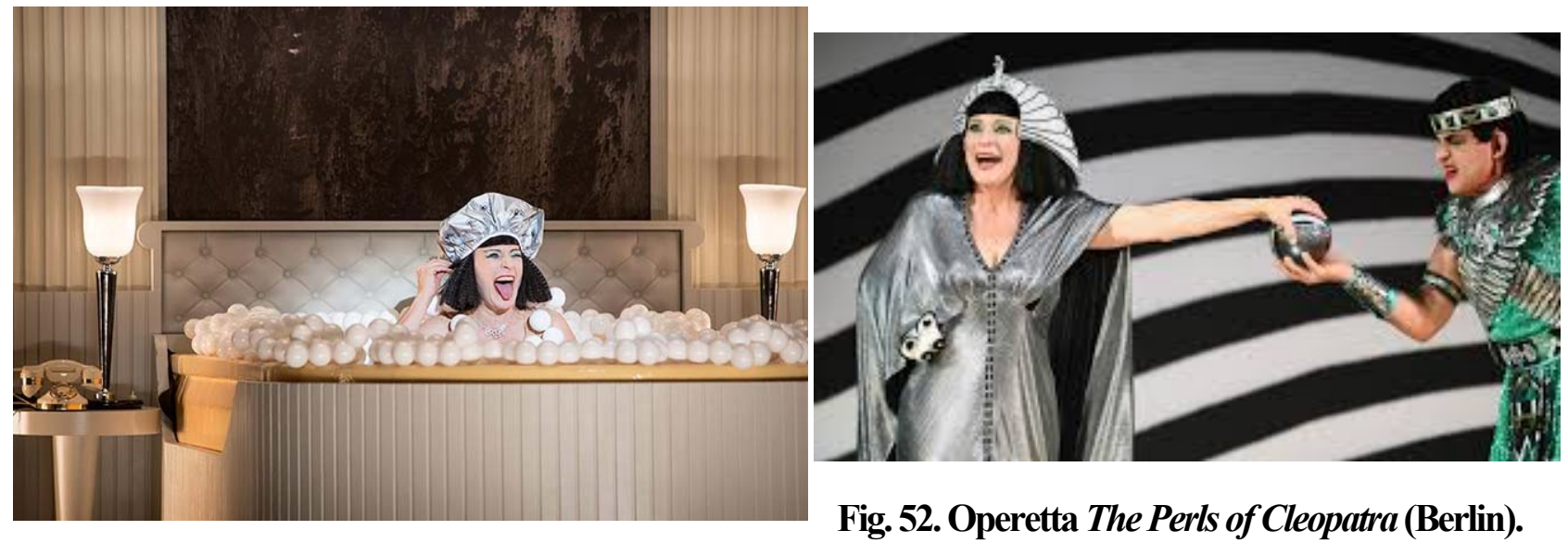

Fig. 52. Operetta The Perls of Cleopatra (Berlin).

Fig. 51. Dagmar Manzel as Cleopatra in The Perls of Cleopatra (Berlin, 2018).

Plutarch describing Cleopatra as reclining "beneath a canopy embroidered with gold, decked out to resemble a painting of Aphrodite" (Fig. 53) Cleopatra is depicted as the source of Antony's moral failings: "the love of Cleopatra that befell him was the final ruin....and, if anything good or protective remained, obliterated and destroyed it." Cleopatra invited Antony to spend the winter with her in Egypt, and after a few months of lavish vacation in which the two called themselves the "Inimitable Livers," she gave birth to his twins in

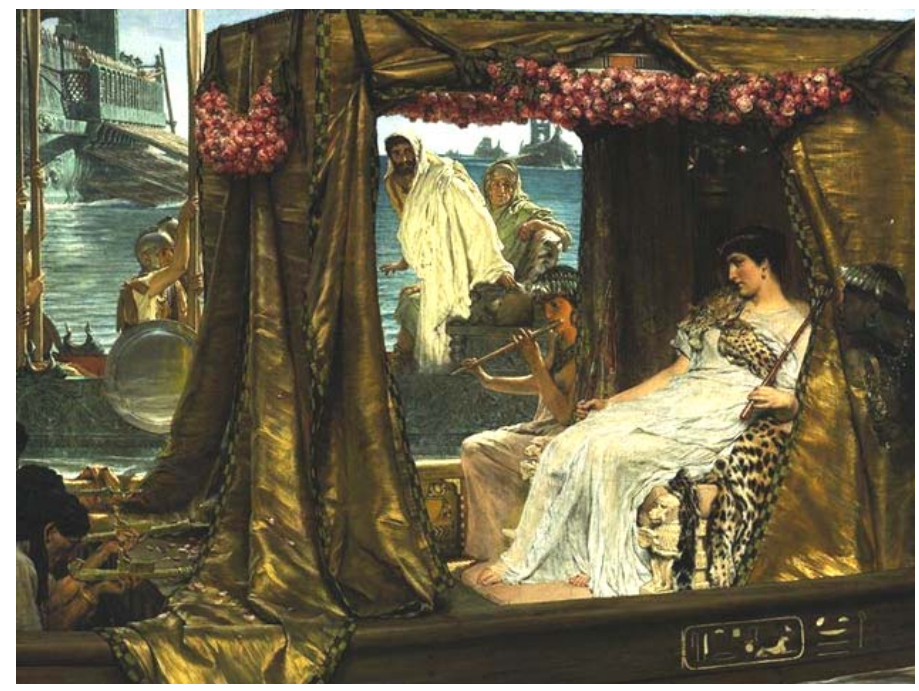
the fall (they had three children Fig. 53. Antony and Cleopatra by Lawrence Alma-Tadema. together twins Selene (Fig. 55) and Alexander (40 BC) (Fig. 56, 57), and Ptolemy (36 BC) (Fig. 58). Antony began giving territory to Cleopatra in $37 \mathrm{BC}$, including Jericho, where Herod was located. The Roman Parthian expedition began in $36 \mathrm{BC}$, and Cleopatra followed

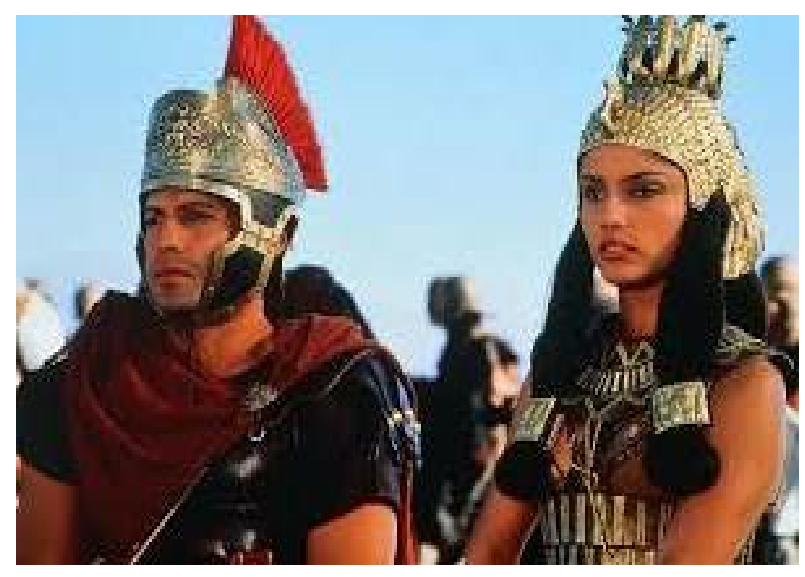
Antony to the Euphrates [2, p. 120] (Fig. 59). Fig. 59. Cleopatra (1999, USA, Germany).

In $34 \mathrm{BC}$ Cleopatra and Antony celebrated a ceremony known as the Donations of Alexandria, where they divided their territories between themselves and their 
children (Fig. 55-58) and Caesarion son of Caesar (Fig. 59). This further destroyed the already hostile relationship between Octavian and Antony. Octavian's allies depicted
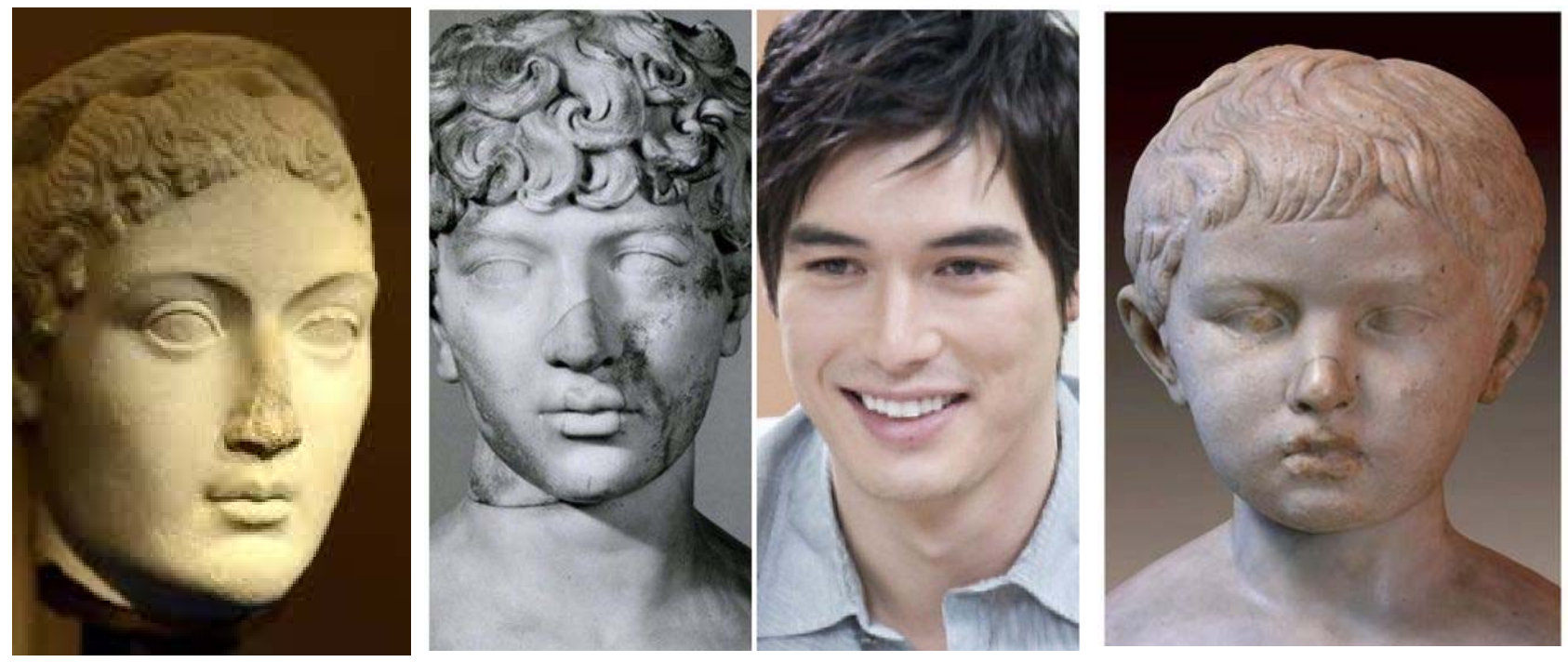

Fig. 55. Cleopatra Selene. Fig. 56. Alexander Helios. Fig. 57. Modern Alexandr Helioc. Fig. 58. Ptolemy.

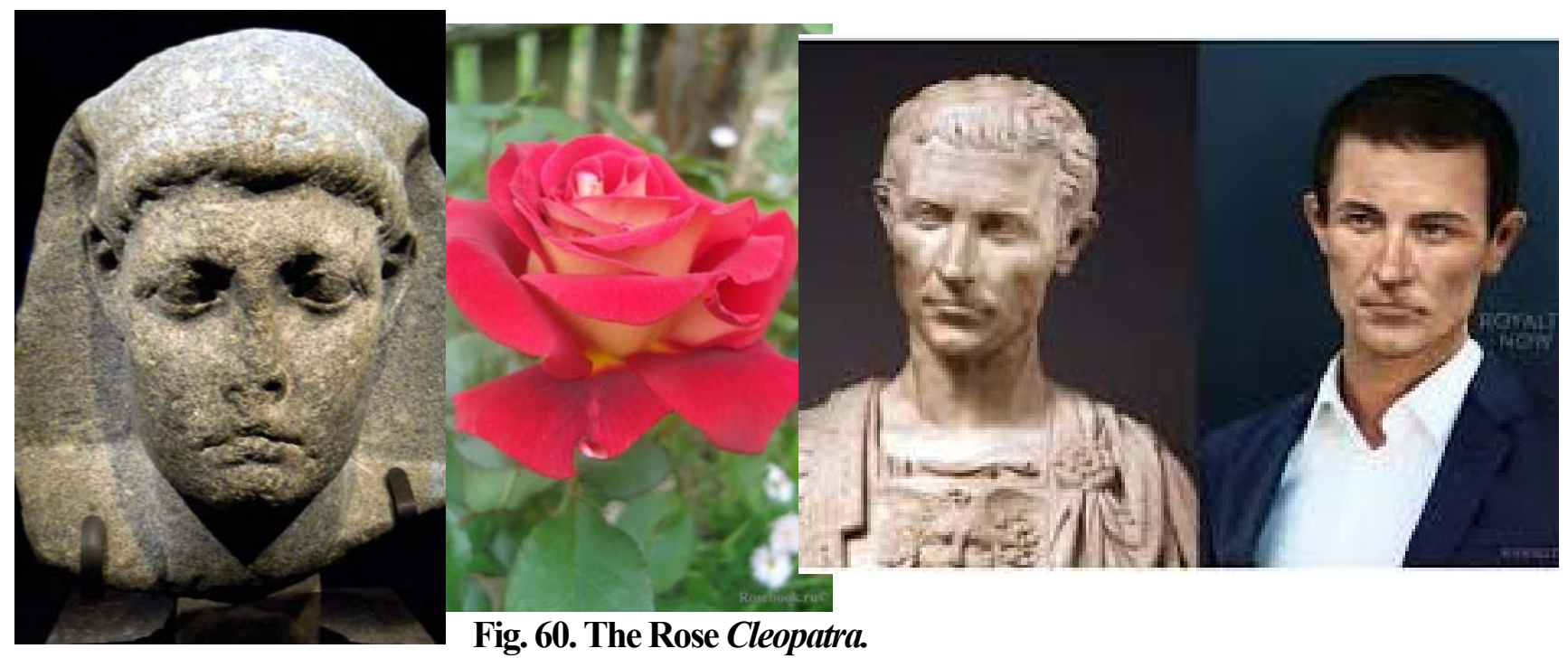

Fig. 59. Caesarion son of Caesar.

Fig. 61. Julius Caesar. Fig. 62. Julius Modern Caesar.

Cleopatra negatively, putting the blame for Antony's misdeeds on her alone. This can be seen in Cassius Dio's rendition of Octavian's speech, "Antony himself, twice a consul, many times a commander... who would not weep to see that he...bows before that woman?" Octavian and Antony's triumvirate expired at the end of 33 BC (see video [78]), and the following year Octavian took the Senate while Cleopatra and Antony raised a naval fleet. Cleopatra and Antony lost the Battle of Actium in $31 \mathrm{BC}$ and Octavian invaded Egypt in 30 BC. Antony's fleets defected to Octavian [2, p. 121].

Boccaccio sees her suicide as a good decision, stating that "the wretched woman put an end to her greed, her concupiscence, and her life." While Cleopatra's 
Roman contemporaries respected her suicide as a noble, dignified way to avoid being further humiliated in Octavian's triumph, Boccaccio respects Cleopatra's suicide because it seems to him to be the first good decision she made. By ending her life, Cleopatra destroys her own greed and lust, preventing her from being more of a danger to society. However, Boccaccio spends comparatively little time on this narrative of Cleopatra's death [2, p. 121], see video [43].

Fabled for her sexual allure and cunning intelligence, Cleopatra VII of Egypt has fascinated generations of admirers and detractors since her tumultuous life ended in suicide on Octavian's capture of Egypt in $30 \mathrm{BC}$. The last of the Ptolemaic monarchs who had ruled Egypt as Hellenistic Greek kings and Egyptian pharaohs for 300 years, Cleopatra created her own mythology, becoming an icon in her own lifetime and even more so after her death [130].

Historical paintings were often officially sanctioned because they were valued as a method of instruction. Incidentally, government endorsement was worth a great deal to the painter. Painters saw this as a gravy train, and tried to ingratiate themselves to their governments through works that embellished loved figures... To take liberties with a Winston Churchill quote, "History is painted by the victors" [65].

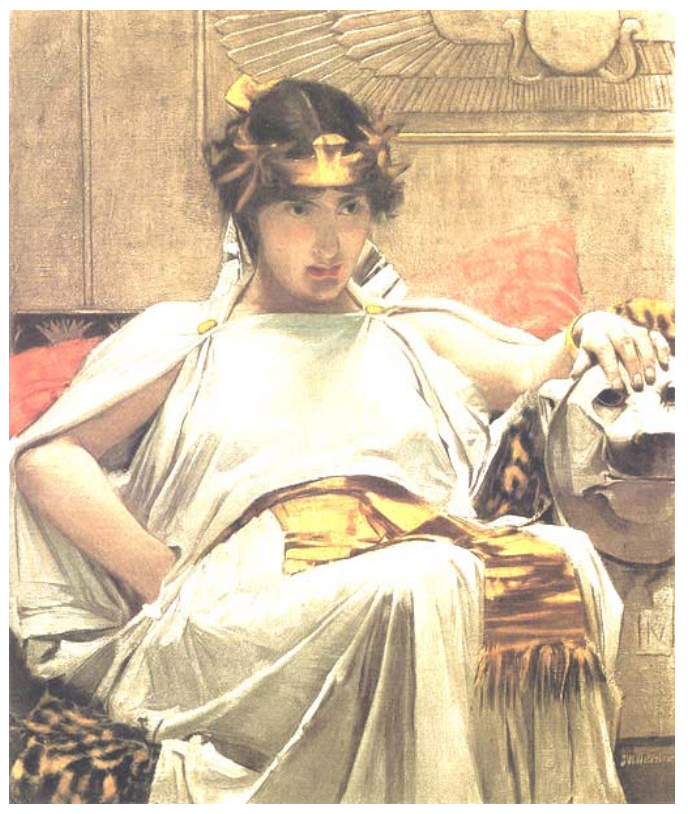

In 1887, The Graphic, an illustrated London weekly, commissioned an exhibit of twenty-one paintings of Shakespeare's heroines. For the Victorians, who idealized the beauty and demure modesty of women, this portrait of Cleopatra (1887) by John William Waterhouse (Fig. 63), must have been a problematic figure. Here, uncorseted and unashamed, Cleopatra is portrayed as femme fatale, lounging on a leopard skin (in much the same way as she does in Alma-Tadema's

Fig. 63. Cleopatra by John William Waterhouse. Antony and Cleopatra (Fig. 53), her sultry gaze defying the viewer, as seductive and potentially poisonous as the asp that bit her - and so the telling quotation from Shakespeare that accompanied the picture when 
the series was reproduced: "Where's my serpent of old Nile? For so he calls me" (I.v) [119].

Cleopatra joined Julius Caesar in Rome beginning in 46 B.C., and her presence seems to have caused quite a stir. Caesar didn't hide that she was his mistress -she even came to the city with their lovechild, Caesarion (see video [32], (Fig. 64, 65), in tow - and many Romans were scandalized when he erected a gilded statue of her in the temple of Venus Genetrix. Cleopatra was forced to flee Rome after Caesar was stabbed to death in the Roman senate in 44 B.C. (see videos $[25,3]$, but by then she had made her mark on the city. Her exotic hairstyle and pearl jewelry became a fashion trend, and according to the historian Joann Fletcher, "so many Roman women adopted the 'Cleopatra look' that their statuary has often been mistaken for Cleopatra herself" [118].

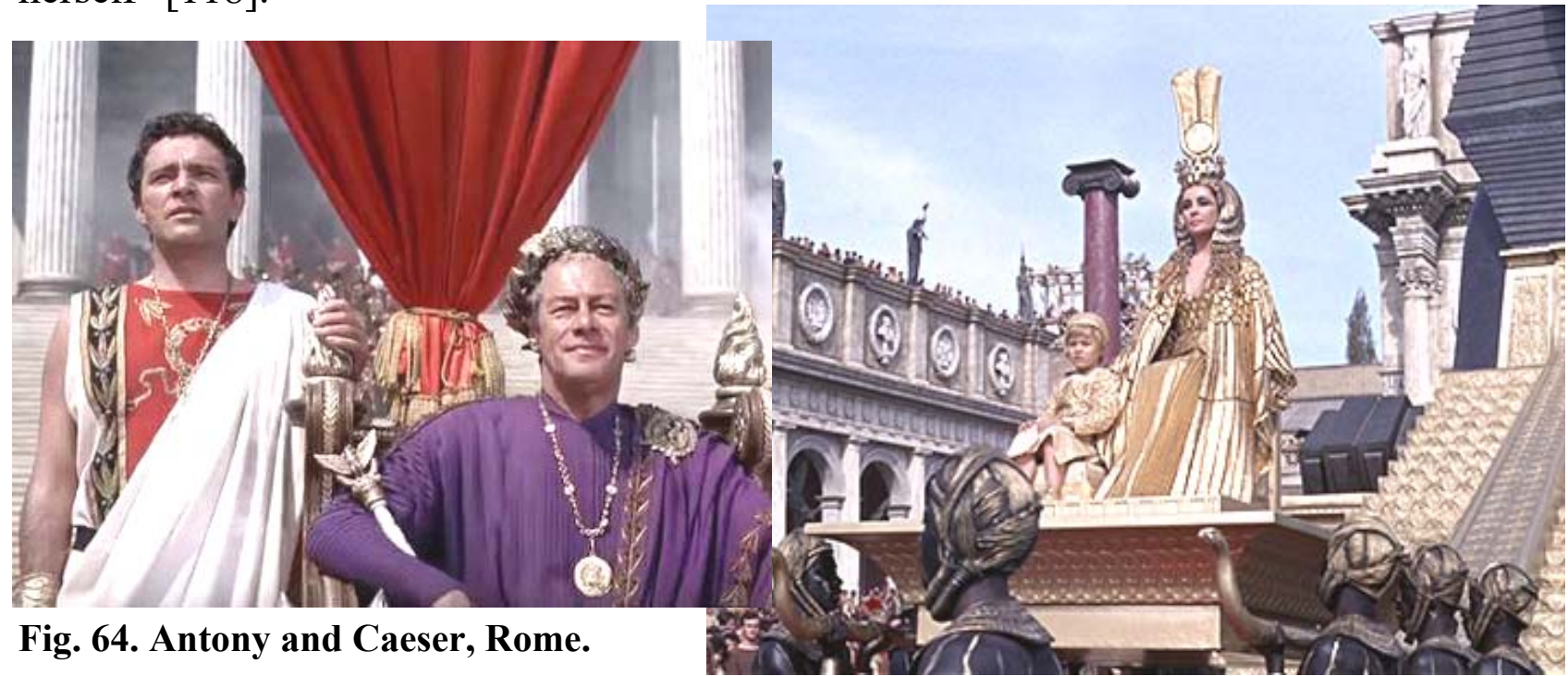

Fig. 65. Cleopatra's entrance into Rome Scene (Cleopatra, 1963).

Julius Caesar was highly successful. He was also highly talented across a remarkable range of activities. Caesar and his adopted son Augustus (future Emperor Octavian Augustus (27 BC-14 AD, founder of the Roman Empire (Fig. 66) were both very clever, even if their characters were different. Mark Antony had none of their subtlety [69], see videos [57; 23].

Jonathan Stamp, Historical Consultant for "Rome" (see the video [6]), discusses the historical background

of Antony and Cleopatra's relationship and how Fig. 66. Emperor Octavian Augustus.

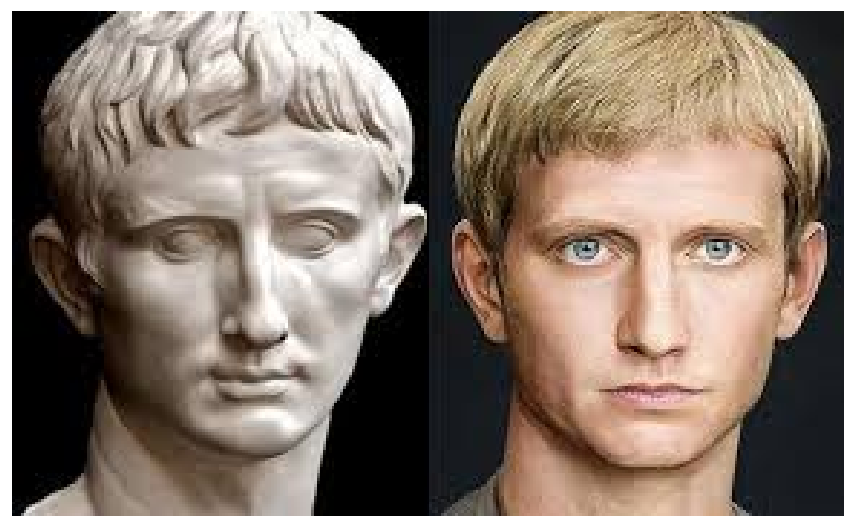


it was depicted in 'Rome.' Mark Antony and Cleopatra challenged Caesar Augustus for control of the Roman Empire more than two millenia ago. Their armies were defeated and rather than submit to capture, the lovers committed suicide - Mark Antony by his sword, Cleopatra with a poisonous asp [108].

The world has had a permanent fascination with Cleopatra for ages, as iconic works about her include a 1960s film (Fig. 64, 65) and a play by William Shakespeare [133].

Antony and Cleopatra is one of the most mature of William Shakespeare's tragedies (Fig. 67, 69). As such, it is arguably one of his finest and deepest works. Pride, love, and the Fall all factor into the play as much as does the contest between temporal politics and eternal love. Antony and Cleopatra are passionate and energetic and are in full bloom beside each other [69, p. 7].

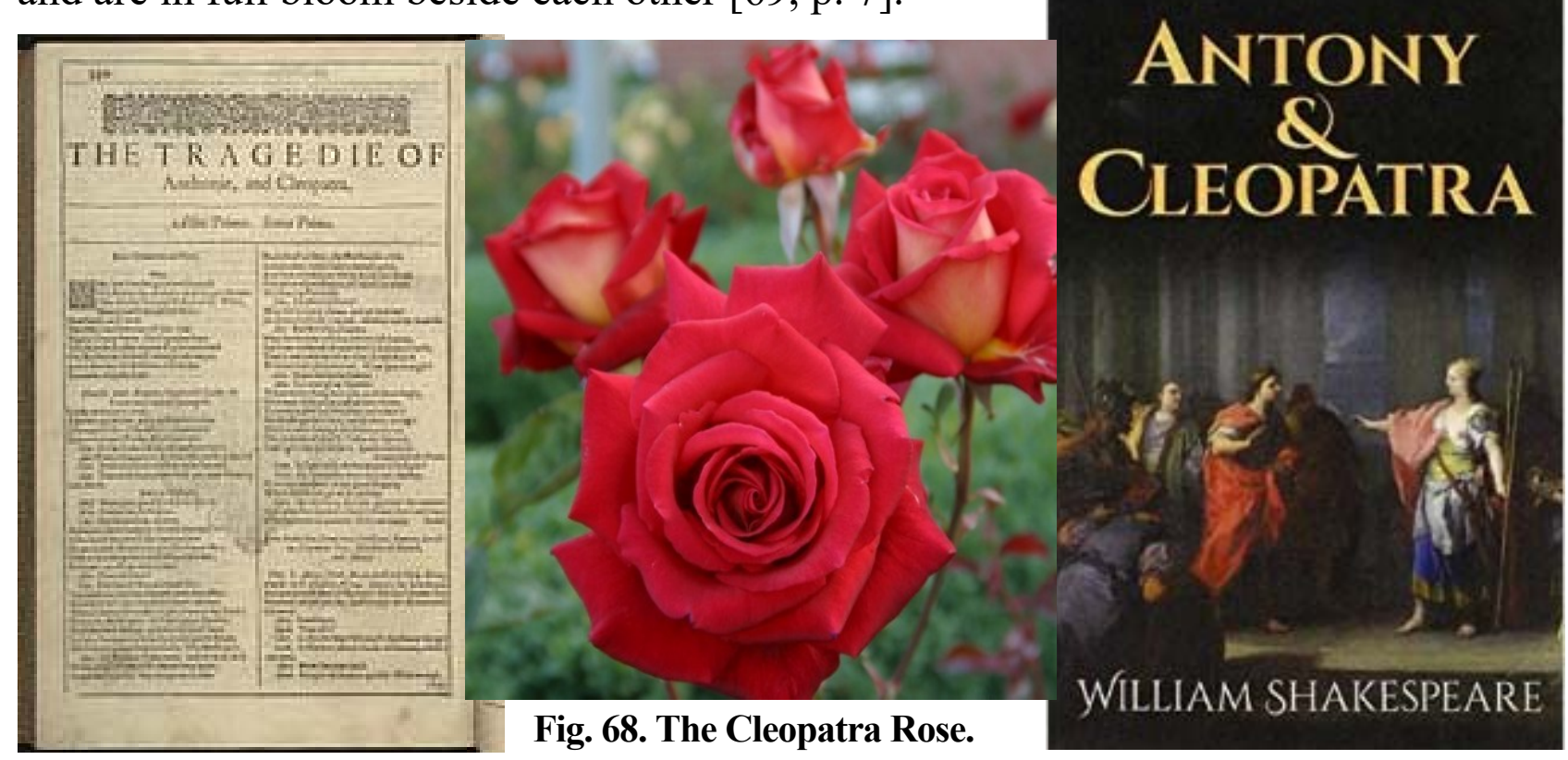

Fig. 67. The first page of Antony and Cleopatra from Cleopatra . the First Folio of Shakespeare's plays, published in 1623.

Fig. 69. Tragedy Antony and

The play Antony and Cleopatra by Shakespeare [8] (see video [137]) is almost true history of the later years of the doomed affair between the Roman general Mark Antony (Fig. 72), and Cleopatra, the last pharaoh of Egypt [127]. The historical events it is based on lead directly to the birth of the Roman Empire (replacing the Republic), and to the annexing of Egypt as a province. Following the assassination of Caesar, she was forced to seek another powerful patron to keep both herself and Egypt safe, and sided with Mark Antony, Octavius Caesar and Lepidus; the men fell out over political differences, and as Antony's wife, she found herself on the losing 
side of the conflict [1].

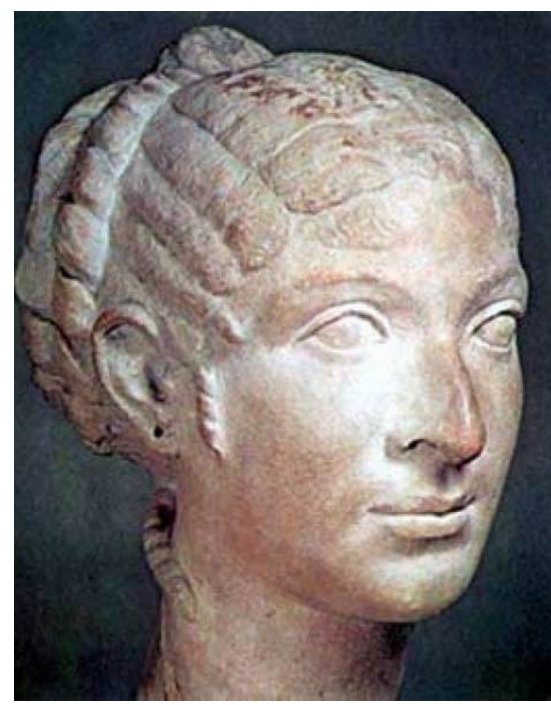

Fig. 70. Cleopatra.

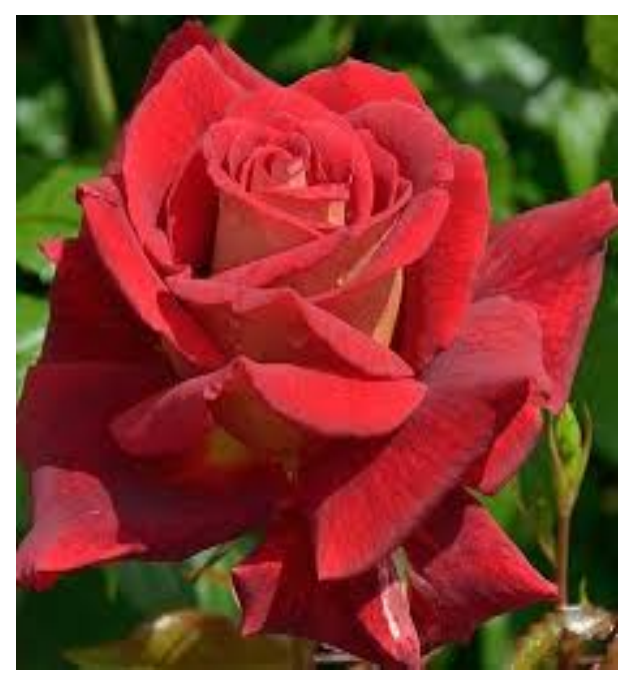

Fig. 71. The Cleopatra Rose.

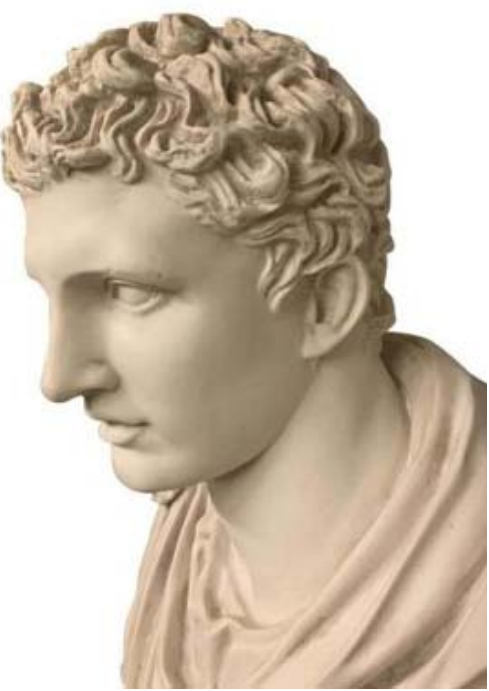

Fig. 72 Mark Antony.

Love is natural. Love is pre-political. Love belongs to "Nature's infinite book of secrecy." To live in the mystery of nature is to dwell in the timelessness of love. That is the sin of Antony and Cleopatra more than their lust and love for each other [26, p. 7], video [5], Fig. 73, 74.

"If it be love indeed, tell me how much," Cleopatra says to Antony in the first scene. "There's beggary in the love that can be reckoned," Antony answers. "I'll set a bourn how far to be beloved," Cleopatra responds. "Then

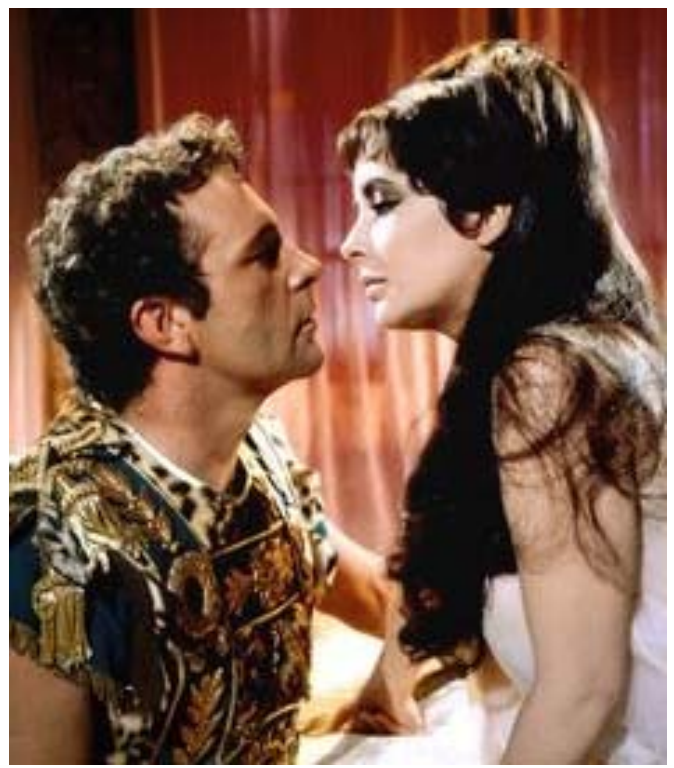
must thou needs find out new heaven, Fig. 73. Antony and Cleopatra (Cleopatra, 1963). new earth," Antony concludes. In their dialogue on love we also see the prefiguration of love's timelessness: "new heaven" and "new earth" are the product of love $[9$, p. 7], see videos $[79 ; \mathbf{1 0 6} ; \mathbf{4 0} ; \mathbf{3 4 ]}$.

Cleopatra is the centre of the play much of the time Antony is merely reacting to her, and her presence is felt even when

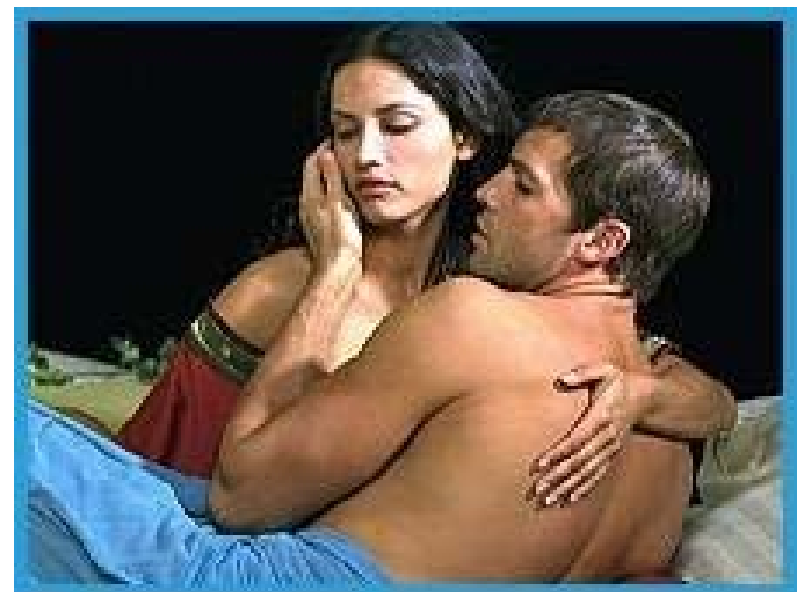

Fig. 74. Cleopatra, 1999. 
she's not on the stage. Yet, she's ambiguous. She spends much of the first half of the play as lovesick for her man, overplaying her longing as if she was performing, and when they finally go into war, she doesn't transform into a forceful, strong queen, but continues to lean on the men around her (see video [7; 35]). She only shows defiance in the end, after she has been defeated, and does it by killing herself rather than live on to be paraded in triumph by Octavius. She is narcissistic and histrionic through much of the play, putting on an exaggerated display of her emotions, but in the end she somehow finally manages to become sincere. She has played and lost, and knows she must join her lover in death [1].

Cleopatra's speech at the end of Act 5, scene 1, after Antony's death is quite good (Fig. 75, 76):

No more, but e'en a woman, and commanded By such poor passion as the maid that milks And does the meanest chares. It were for me To throw my sceptre at the injurious gods; To tell them that this world did equal theirs Till they had stol'n our jewel. All's but naught; Patience is scottish, and impatience does Become a dog that's mad: then is it sin To rush into the secret house of death, Ere death dare come to us? How do you, women? What, what! good cheer! Why, how now, Charmian! My noble girls! Ah, women, women, look, Our lamp is spent, it's out! Good sirs, take heart: We'll bury him; and then, what's brave, what's noble, Let's do it after the high Roman fashion, And make death proud to take us. Come, away: This case of that huge spirit now is cold: Ah, women, women! come; we have no friend But resolution, and the briefest end.

\section{Shaikspear. Antony and Cleopatra,} Act 5, scene 1.

Fig. 76. Cleopatra (1963). Antony and Cleopatra are famous.

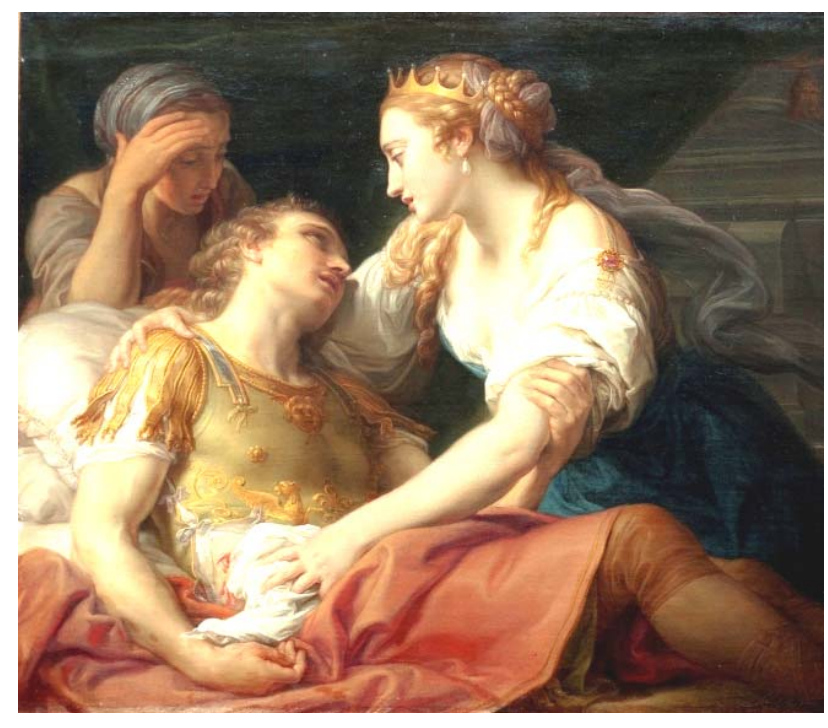

Fig. 75.The Death of Mark Antony (1759) by French artist Bernard Duvivier

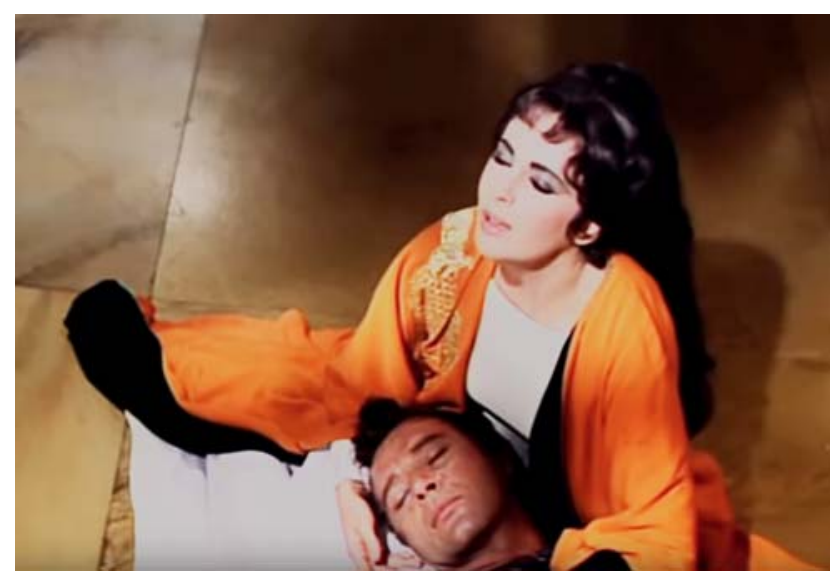

With just a handful of others, including Caesar, Alexander the Great, Nero, Plato and Aristotle, they remain household names more than two thousand years after their spectacular suicides. Cleopatra is the only woman in the list, which in itself is interesting and a testament to her enduring fascination. Yet most often Antony and Cleopatra are remembered as a couple, and as lovers - perhaps the most famous 
lovers from history. Shakespeare's play helped them to grow into fictional characters as well, and so their story can now be numbered alongside other tales of passionate, but doomed romance, as tragic as the finale of Romeo and Juliet [69; 114], Fig. 76, 77.

Cleopatra is not portrayed as a seductive killer and schemer, though she was certainly that in real life... Shakespeare does what all great artists do - he takes historical characters and brings them to life, but in doing so, also communicates through them timeless truths and reflections which endure long after the death of the artist $[9$, p. 8$]$.

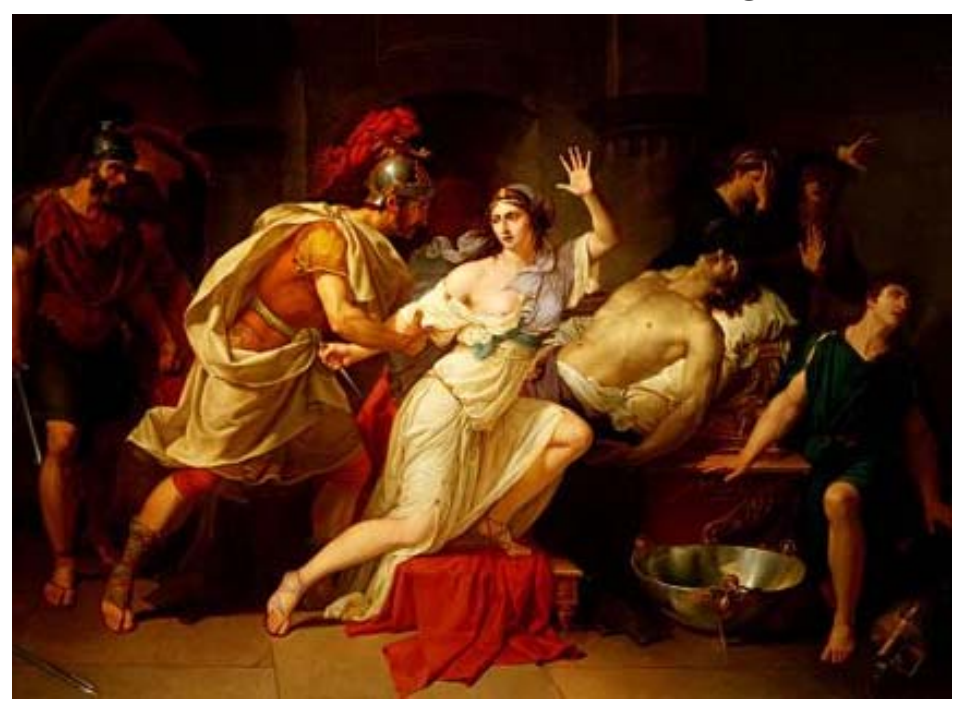

Fig. 77. 'Cleopatra Captured by Roman Soldiers after the Death of Mark Antony' by B. Duvivier 1789.

Delacroix's artwork, similarly to Shakespeare's, first draws the audience's attention to Cleopatra (Fig. 78). When viewing Delacroix's Cleopatra and the Peasant, the eye instantly falls upon the beautiful, white face of the queen. Her pristine skin illuminates the chamber in which she sits and her jewelry sparkles brilliantly. Luxurious jewels adorn her right arm, her neck and her crown, reinforcing the contrast with her pale flesh as well as giving away her royal status. Delacroix immediately bestows upon her an almost immortal persona with her radiance and extensive signs of wealth. Shakespeare paints a similar picture of the fair queen within his play. The audience first sees Cleopatra in her Alexandrian Palace, as eunuchs fan her and her court stands around her. Immediately

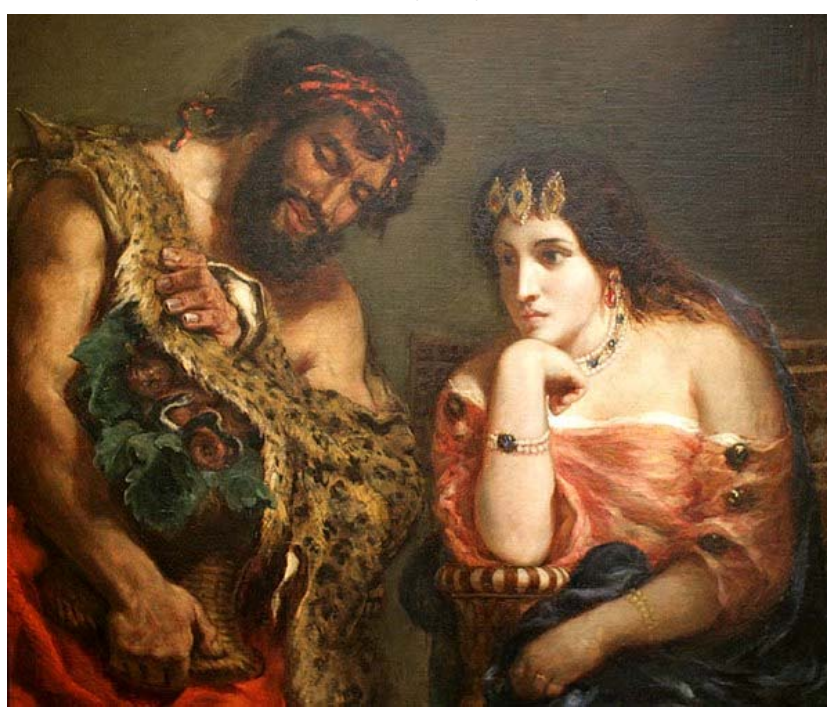

Fig. 78. "Cleopatra and Peasant" by Eugène Delacroix 1838

Shakespeare establishes her nobility and her importance. To Antony, she is worth his reputation; she is worth everything he owns.

With Octavian's troops marching towards Alexandria, Antony rejoined the battle. Cleopatra, meanwhile, hid herself away in her mausoleum, along with her treasure and two maidservants. Antony picked up information that Cleopatra was dead. Devastated, he fell upon his sword, saying, according to Ancient Greek biographer Plutarch: "I am not pained to be bereft of you, for at once I will be where 
you are, but it does pain me that $\mathrm{I}$, as a commander, am revealed to be inferior to a woman in courage." Antony then received word that Cleopatra was still alive. Fatally wounded, he was taken to her. The queen was distraught but, before he succumbed to death, Antony asked her to make peace with Octavian.

Octavian, however, wasn't doing any deals. He wanted Cleopatra as a trophy to parade in Rome. While Cleopatra's demise might have taken the edge off of Octavian's victory parade, he was greeted back in Rome as the conquering hero. He now had absolute power over the richest kingdom along the Mediterranean Sea. Egypt had become a mere province for Rome, one of the largest, most powerful empires of the ancient world, to plunder. It would remain under Roman rule until the 7 th century [135].

There are several problems with this theory, according to modern Egyptologists. For one thing, cobras were typically at least five feet long, and could grow up to eight feet; much too large to smuggle into Cleopatra's mausoleum in a basket of figs, as the story goes. In addition, not all snake bites (video [118]) are deadly, and those that are kill their victims slowly and painfully, making it hard to believe a snake was able to kill Cleopatra and her two maids in the short time it took for Octavian to receive her note and send his guards [101].

Cleopatra was the last Queen of Egypt, a Ptolemeic Pharaoh, who bore Julius Ceasar a son, and became the lover of Mark Anthony in order to protect the interests of her country in the face of an all-powerful Roman Empire. Once Mark Anthony had been defeated at the battle of Actium (30 B.C.), and fallen on his sword (Fig. 80, 81, 82, see video [85]), she herself commited suicide to avoid capture by Octavian. An asp, or Egyptian cobra, was smuggled to

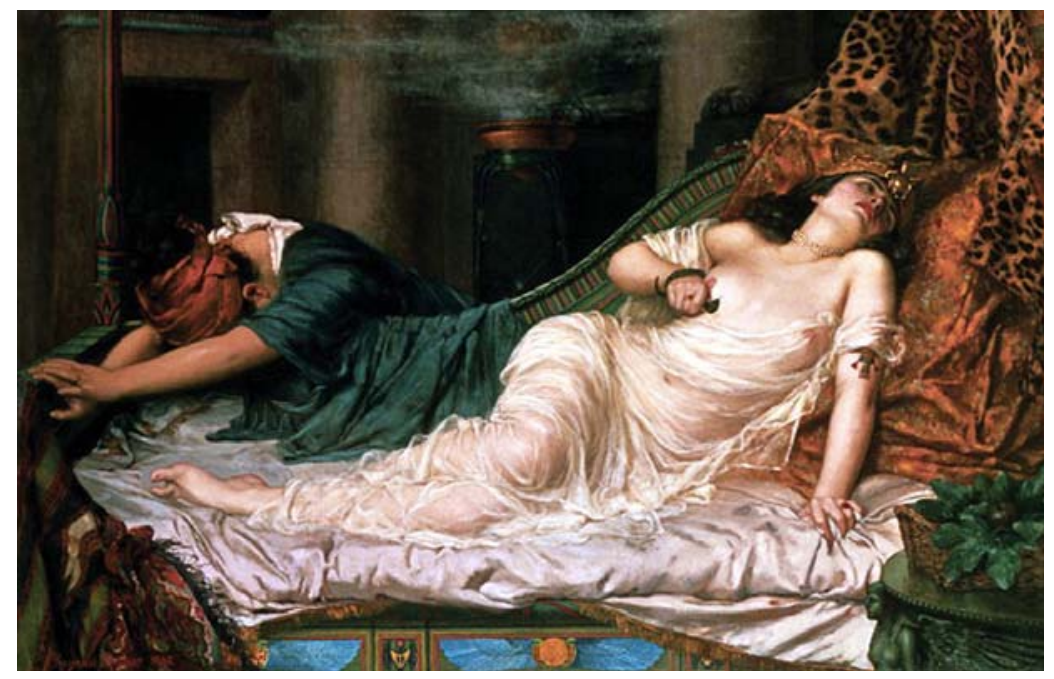
her in a basket of figs and she Fig. 79. The Death of Cleopatra by Reginalda Arthur, 1892. died from itsbite. According to Egyptian legend, death from snakebite ensured immortality. The courage involved in her suicide impressed many, and Arthur Reginalda has appended to his title well known thoughts of the philosopher Francis Bacon (1561-1624): 'I do not believe that any man fears to be dead, but only the stroke of death'. Arthur's representation is typical of the exoticism found in much fin-de-siècle art. Cleopatra is draped in the most diaphanous of materials, and 
expires in a haze of incense on a bed inlaid with semi-precious stones and strewn with tiger skins and shawls [102].

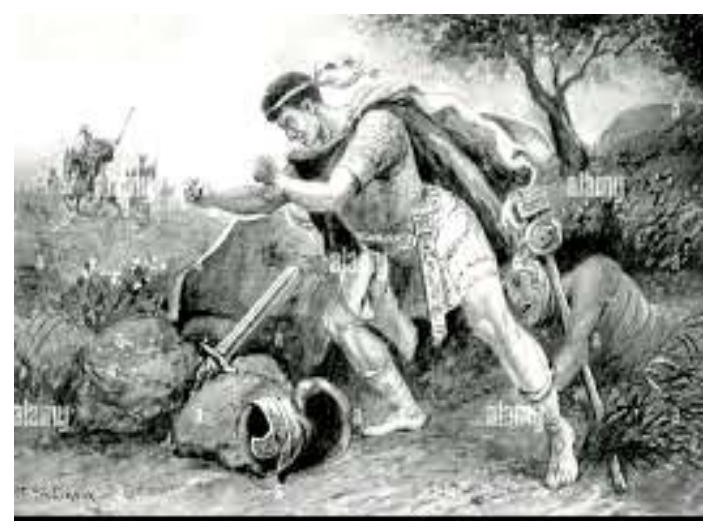

Fig. 80. Mark Anthony suicide
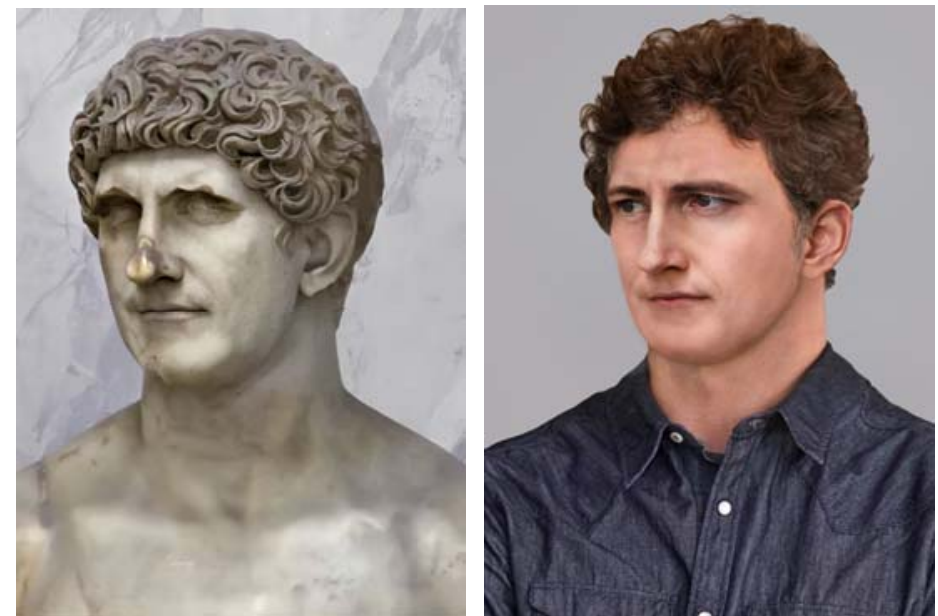

Fig. 81. Mark Antony. Fig. 82. Modern Mark Antony.

If Cleopatra did poison herself to death, it's more likely she drank an lethal herbal concoction, or applied a toxic ointment, as one ancient historian, Strabo, suggested. Either of these would have killed her (and her servants) more quickly and effectively than a snake bite... (Fig. 82, see video [42]). In 2010, the German historian Christoph Schaefer suggested that Cleopatra may have ingested a fatal mix of hemlock, wolfsbane and opium, based on his studies of ancient documents and his work with a toxicologist [101].

The truth, however, remains elusive. With no known eyewitnesses to and no primary written accounts of Cleopatra's

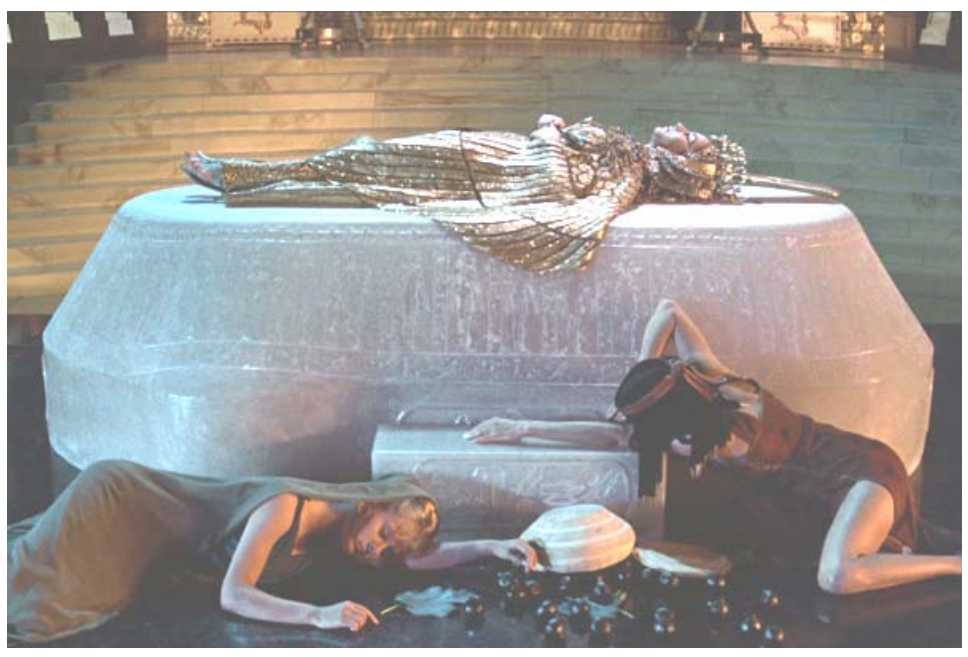
death, much of what we know comes Fig. 82. The death of Cleopatra (Cleopatra, 1963). from Octavian - who some have suggested is a suspect himself. He certainly had a motive to want Cleopatra dead... (see the video [125]) Whether or not Octavian ordered the murder of Cleopatra and her maidservants, or simpy provided her the space and opportunity to kill herself, what happened next is clear: He directed his guards to hunt down and kill Caesarion, Cleopatra's teenage son with Caesar to remove any question of the boy's succeeding his mother on the throne. Octavian then made Egypt a Roman province, with himself as emperor; he later took the name Augustus [101]. 
The ancient historian Plutarch, per Ancient History Encyclopedia, wrote that the two were buried together, probably at Cleopatra's request, though Plutarch never revealed the location of their tomb. Most people think their final resting place is in Alexandria, a beloved city of the pharaohs, but most of which today lies under the sea. Some scientists, however, claim both are buried beneath the Temple of Taposiris Magna [121], Fig. 83.

"She was the fabled queen of ancient Egypt, immortalised over thousands of years as a beautiful seductress. But, despite her fame, Cleopatra's tomb is one of the great unsolved mysteries. Some believe she was buried in Alexandria, where she was born and ruled from her royal palace, a city decimated by the tsunami of $365 \mathrm{AD}$. Others suggest her final resting place could be about 30 miles away, in the ancient temple of Taposiris Magna, built by her Ptolemaic ancestors on the Nile Delta", says Dr Kathleen Martínez [61], see video [60].

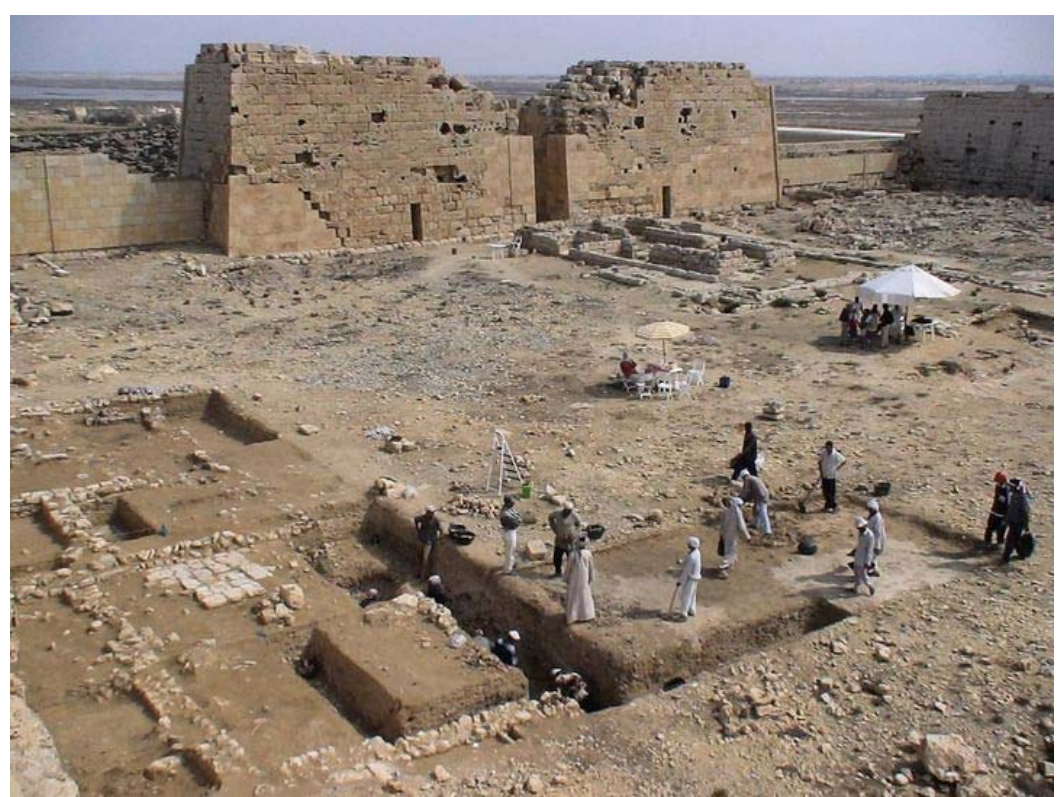

Fig. 83. The Temple of Taposiris Magna.

Excavations at Taposiris Magna are headed by, who, after working there for over 14 years, is more convinced than ever Cleopatra's tomb will be found there [67]. Will Cleopatra's tomb ever be found? With unimaginable wealth and power, Cleopatra was the greatest woman of an era and one of the most iconic figures of the ancient world. ... Martinez has devoted nearly two decades of her life to perhaps the greatest mystery of all: Cleopatra's tomb has never been found [87].

As we wrote earlier The scientests explore the ways in which she was depicted in antiquity, within the context of the iconography of contemporary coinage, statues and other images of Egyptian, Greek and Roman rulers, and then examines the image of Cleopatra from the Renaissance to modern times, as seen in plays, opera, painting, ceramics and even jewellery [130], see the video [116].

In this way we must remember the opera Giulio Cesare in Egitto (1724) by Georg Fridrich Haendel, libretto by Nicola Francesco Haym [68]. The opera was composed in the United Kingdom in 1724 (see video [144]). Georg Fridrich 
Haendel (1685-1759) )was a German-British Baroque composer well known for his operas, oratorios, anthems, concerti, grossi and organ concertos.

Panache, burlesque, emotion, a handful of colourful, larger-than-life characters and a host of wonderful arias characterise Giulio Cesare, the quintessential opera seria (even though its subject is only dramatic in part), a major genre in the $18^{\text {th }}$ century that Handel took to great heights. Giulio Cesare is one of forty such works and the most popular one. The principle? A series of arias that range from tender to mischievous, passionate, martial, majestic, tearful, languorous and desperate,
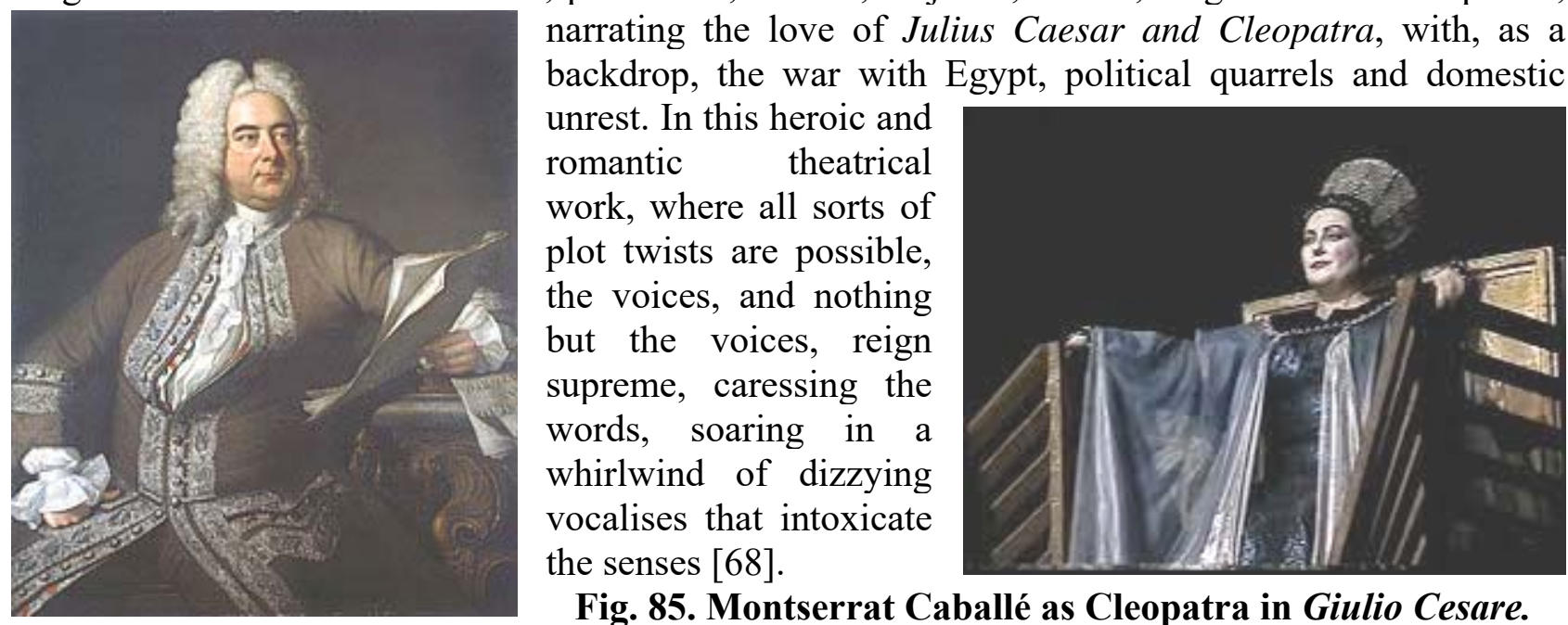

Fig. 84. Portrait of Handel, by Thomas Hudson (c. 1741).

An opera Cléopâtre was also presented to the music world by French composer Jules Massenet (Fig. 86) (1842-1912) in 1912 (see video [87; 103; 39]). It was first performed at the Opera de Monte Carlo on 2323 February 1914, nearly two years after Massenet's death. The story concerns the ill-fated love of Cléopâtre and Mark Antony [38]. The role of Cléopâtre was created by the soprano Maria Kuznetsova-Benois (Fig. 87).
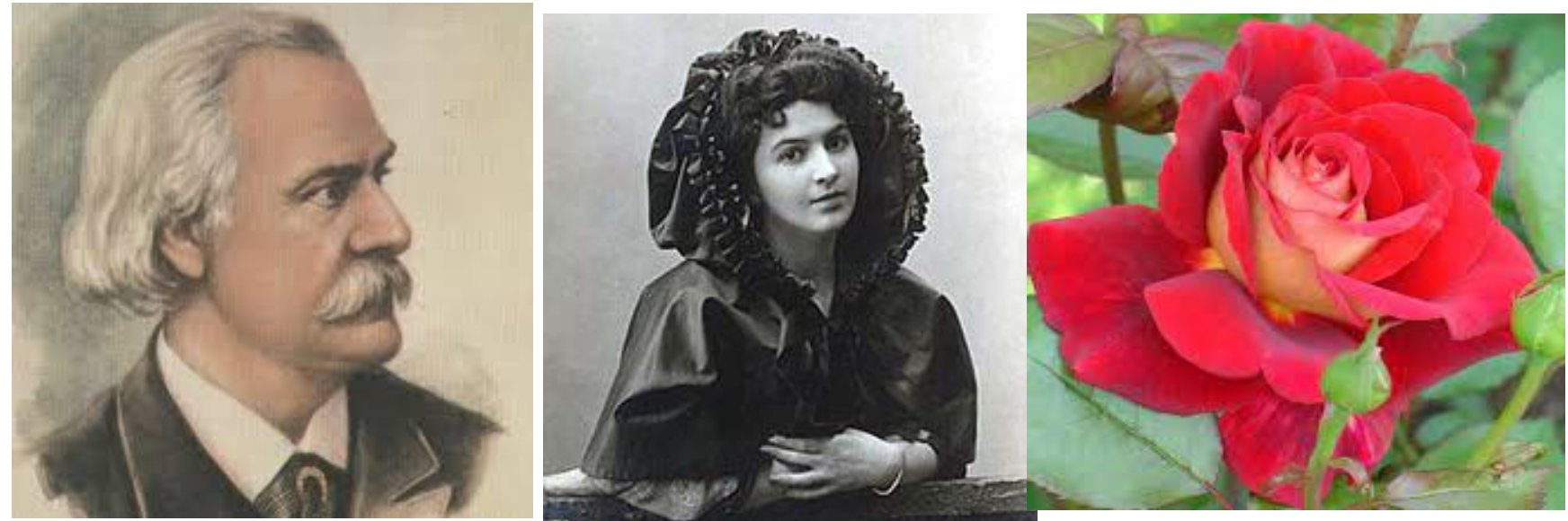

Fig. 86. Jules Massenet.

Fig 87. Maria Kuznetsova-Benois (1914). Fig. 88. The Cleopatra Rose.

Arensky's ballet Egyptian Nights was written in 1900 and first staged at the Mariinsky Theatre in St Petersburg in March 1908, with choreography by Fokin. In 
spite of the obvious exoticism of the subject and the use of apparently authentic melodies, the harmonic language and instrumentation tend to conceal much of this, except in certain obvious dances where characteristic melodic intervals appear. The work is based on Pushkin, as was Glière's 1905 ballet Kleopatra [10].

Arensky's ballet Egyptian Nights was written in 1900 and first staged at the Mariinsky Theatre in St Petersburg in March 1908, with choreography by Fokin. In spite of the obvious exoticism of the subject and the use of apparently authentic melodies, the harmonic language and instrumentation tend to conceal much of this, except in certain obvious dances where characteristic melodic intervals appear. The work is based on Pushkin, as was Glière's 1905 ballet Kleopatra.

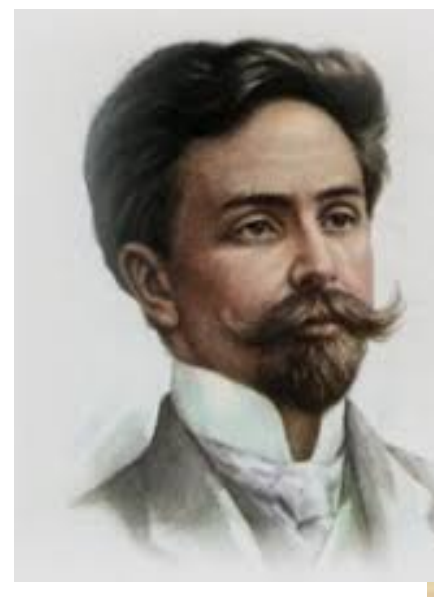

Fig. 89. A. Arensky

(1861-1906)

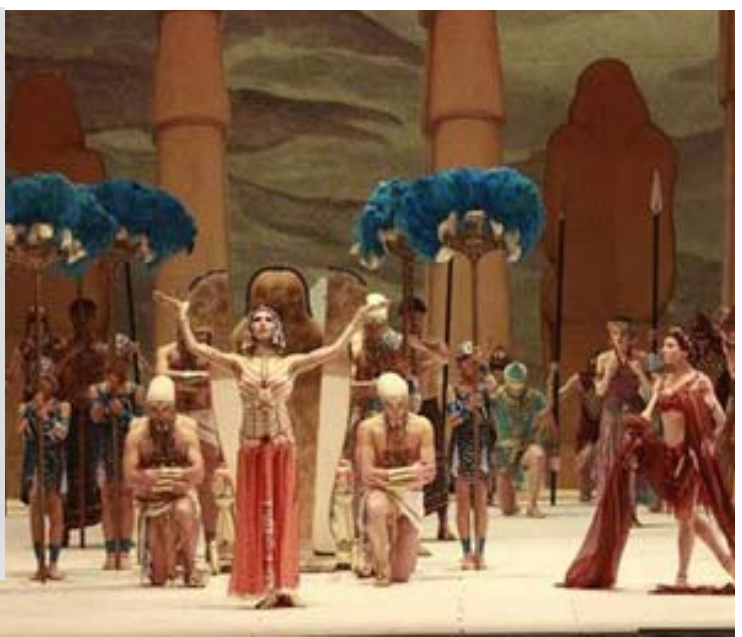

Fig. 90. Dancer Dutch National Ballet, 2014.

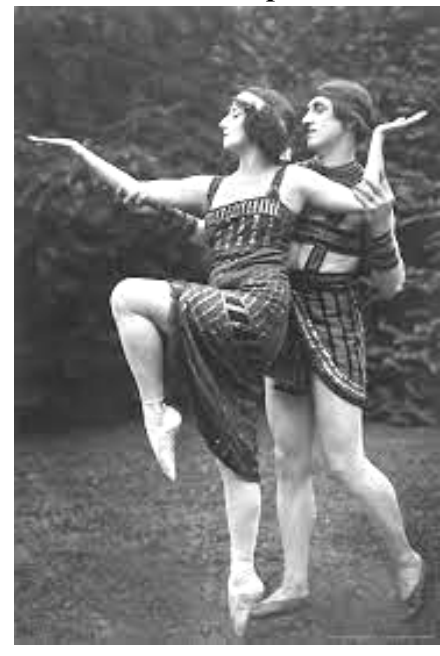

Fig. 91. Anna Paflova Egyptian Nights. as Cleopatra and Lairent Novikoff as Amoun, 1923, London.

One of Arensky's sources explored for authentic melodic material is William Lane's An Account of the Manners and Customs of the Modern Egyptians, published in London in 1836. This provides the principal theme of the Overture, with its lyrical relaxation of tension at its heart and a return to the opening music, before the introduction to the first scene, set by the banks of the Nile. On the right there is a temple and there are palm-trees, with an island in the background and in the distance pyramids and sphinxes. Berenice, followed by her companions, comes out of the temple and goes to the river, to draw water. The key and mood of the music changes as she meets her betrothed, Amoun, a moment for gentle flirtation to music that must recall, in its rhythm at least, an episode in Schumann's Carnaval. Amoun is returning from the hunt, and shows what he has killed. The High Priest of the temple congratulates him and is happy at his coming marriage with Berenice. At this moment a messenger arrives, giving news of Cleopatra's approach.

Cleopatra makes her entrance, to the agitation of Amoun, who falls in love with her, tries to suppress his feelings, but fails. He tries to enter the temple, but is prevented, while Cleopatra goes in, leaving the young man in despair. Cleopatra comes out of the temple again and reclines on a bed prepared for her in the shade of a palm-tree. Arsinoe tries to distract her by her dancing, but cannot do so. Arsinoe's dance is followed by a more exotic dance, as Berenice tries to entertain the queen. At this moment Amoun appears on the temple steps, takes his bow and shoots an arrow straight at the tree under which Cleopatra is sheltering. Alarmed, Cleopatra orders him to be seized and soldiers set out in pursuit. Arsinoe gives Cleopatra the arrow, to which is fixed a long papyrus on which Amoun has written "I love you". Amoun is now brought before Cleopatra, who is struck by his beauty. To her reproaches he can only reply that he loves her and would give his life for one kiss. To a lyrical melody, she gives him to understand that she will grant his wish but that, at the first light of day, he must die, by poison [10] see video [44]. 
An associate English professor at DePaul Univrsity Franceska F. Royster, has crafted a dense but readable book "Becoming Cleopatra: The Shifting Image of an Icon". Moving fluidly from Shakespeare's England to contemporary LA, Francesca Royster looks at the performance of race and sexuality in a wide range of portrayals of that icon of dangerous female sexuality, Cleopatra. Royster begins with Shakespeare's original appropriation of Plutarch, and then moves on to analyze performances of the Cleopatra icon by Josephine Baker (Fig. 84), Elizabeth Taylor (Fig. 85), Pam Grier (Cleopatra Jones, 1973) and Queen Latifah (in Set It Off, 1996). Royster argues that Cleopatra highlights a larger cultural anxiety about women, sexuality, and race [107].
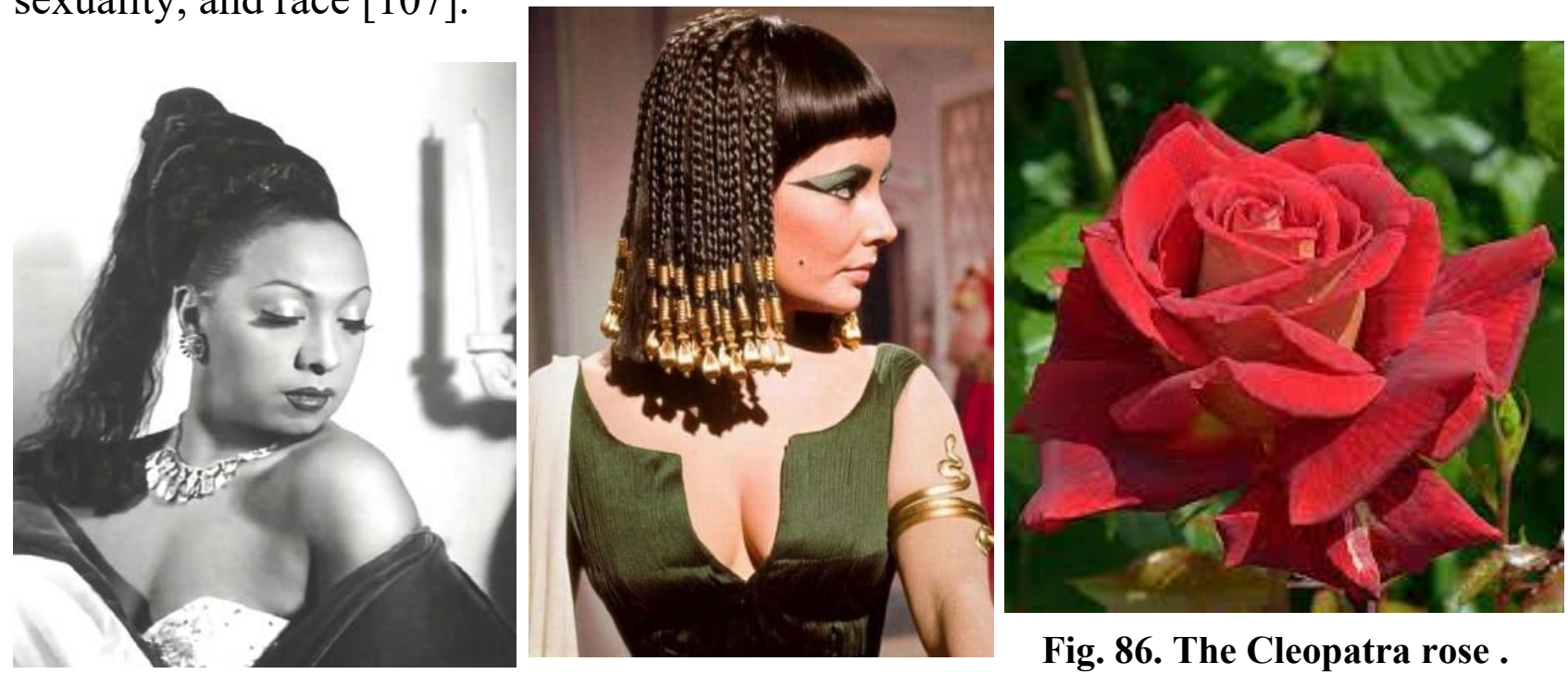

Fig. 86. The Cleopatra rose .

Fig. 84. Josephine Baker as Jazz Cleopatra (1930th). Fig. 55. Elizabeth Taylor as Cleopatra.

And the Roman historian Plutarch said Octavian Augustus allowed the two to be buried together, but their tomb was never found. "...if this tomb is found, it will be one of the most important discoveries of the 21st century because of the love between Cleopatra and Mark Antony, and because of the sad story of their death" [108], see the videos [136; 42].
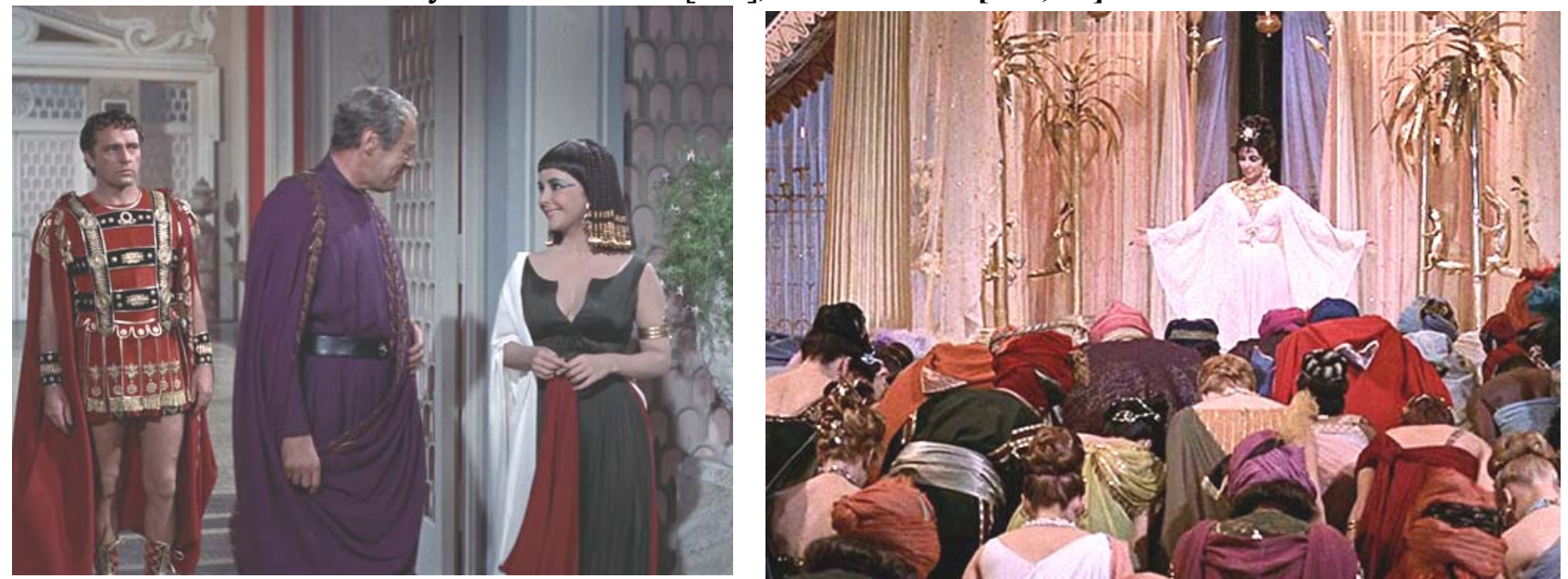

Fig. 87. Antony, Caeser and Cleopatra (Cleopatra, 1963). Fig. 88. Cleopatra as Afrodita on the on the feast. 
Cleopatra loved the lotus flower. She would take a lotus bath every day and would also use the perfume of the lotus blossom to scent the sails of her royal ship. In fact, researchers calculated that her use of floral fragrances to perfume her body would cost the equivalent of $\$ 800$ a day, (Fig. 89). Not only that, but she would also experiment with poisons that would be camouflaged in flowers. At one memorable gathering, she placed a few deadly drops on flower petals and had the flowers woven into the chaplet which Antony was to wear at supper. She playfully plucked the flowers from his head and put the petals into wine. Prior

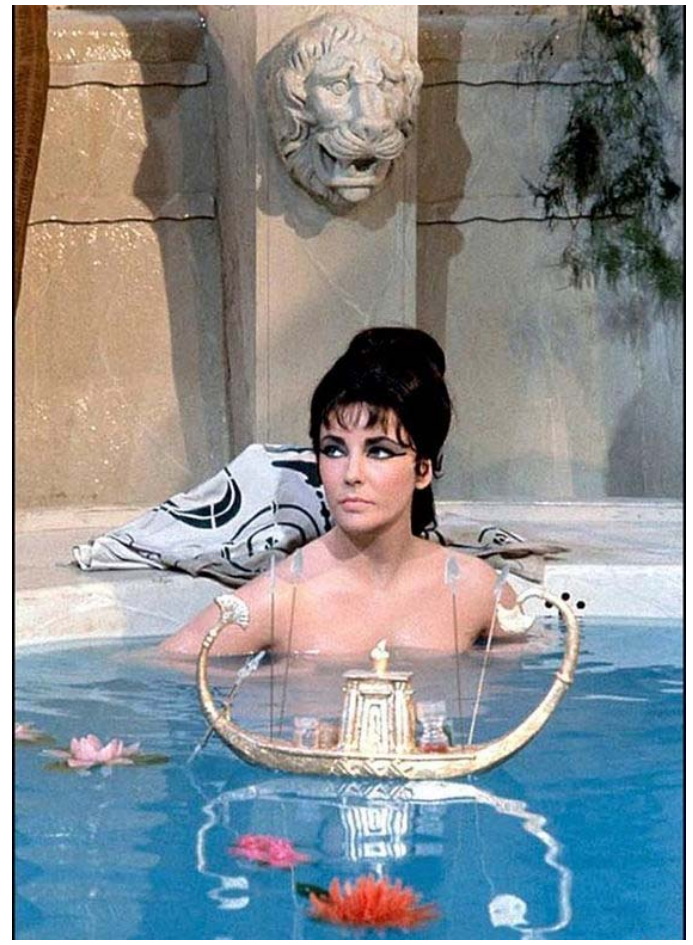

Fig. 89. A lotus bath of Cleopatra. to putting the poisoned wine to his lips, she said, "If it were possible for me to live without you, how easy it would be for me to devise ways and means to kill you" (Fig. 90). But she never did since Antony was the love of her life [20].

Cleopatra remains one of the most iconic female leaders in history. A saint she was not - but she had admirable survival skills.

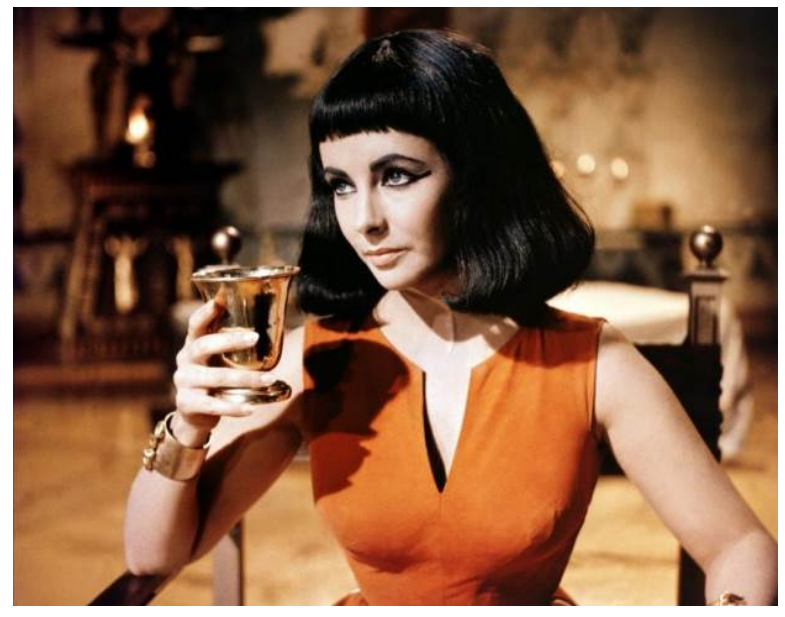

Fig. 90. Cleopatra, 1963.

Cleopatra also learned cunning political skills. She ruled from 52 B.C. to 31 B.C. - a 21-year reign which included her having had some of her siblings killed. Aside from developing perfumes, she also popularized using pearls in jewelry [20].

Mysteries also surround her death. Was it from a snake bite? Some believe it was self-induced since she always had a jeweled hair comb that had a special poison dipped on it [20].

As for this particular history painting "Cleopatra Testing Poisons on Condemned Prisoners" by Alexandre Cabanel, stories and history about Cleopatra always include accounts of poison.

One of Cleopatra's older sisters tried to poison her; her younger brother (and co-ruler of 
Egypt) died mysteriously - probably poisoned - leaving Cleopatra in charge; (although she did appoint her son from Julies Caesar to be her male co-ruler.) Cleopatra was more than somewhat familiar with poison, and Cabanel's painting illustrates a possible method that she may have used to increase her knowledge. This painting shows a coldly interested Cleopatra watching as various poisons are tried on prisoners condemned to death. She's beautiful, and she's as deadly as the asp that was said to kill her. Cabanel shows this very well [65].

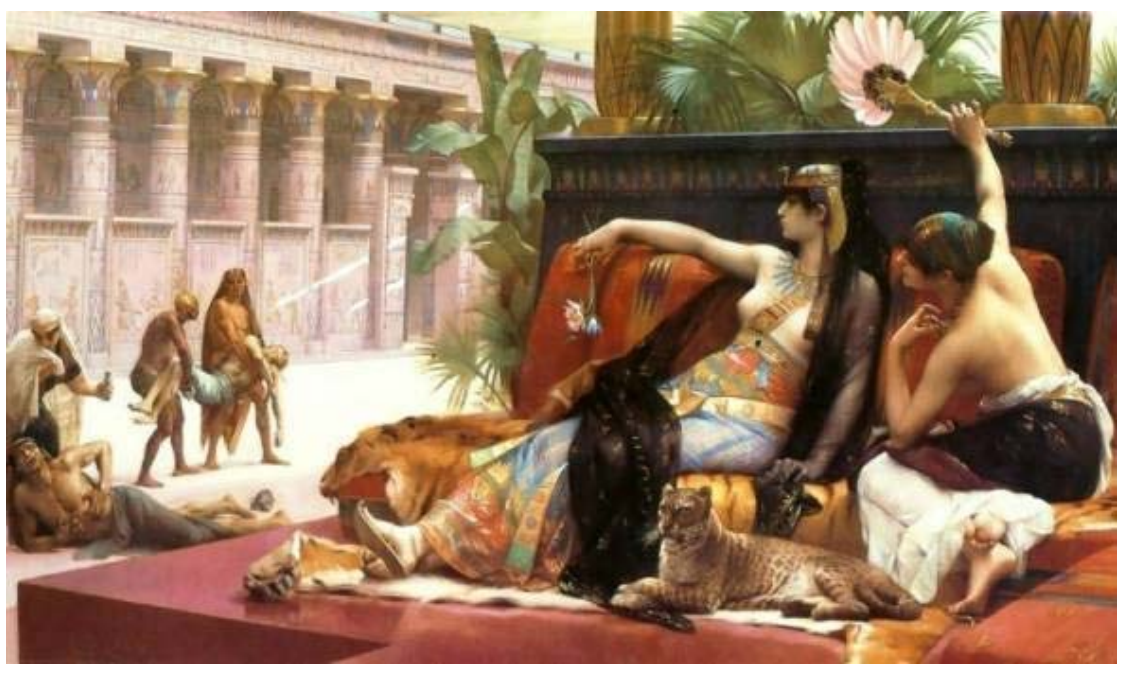

Fig. 91. Cleopatra Testing Poisons on Condemned Prisoners by Cabanel Alexandre, 1897.

And for 2,000 years almost all evidence of Cleopatra had disappeared - until now. Neil Oliver investigates the story of a ruthless queen who would kill her own siblings for power (see video [132]).

Some examples of floriography in Haggard's Cleopatra (1889) where the rose, lotus, poppy and pomegranate contribute to creating a poisonous dramatic setting [115].

We may find further examples of floriography in Haggard's Cleopatra (1889) where the rose, lotus, poppy and pomegranate contribute to creating a poisonous dramatic setting. The 'gothic aesthetic' created through the mummy's curse narrative is enhanced by a garden of poisonous floriography... This 'gothic aesthetic' is not just a subjective imposition, a case of reading the text

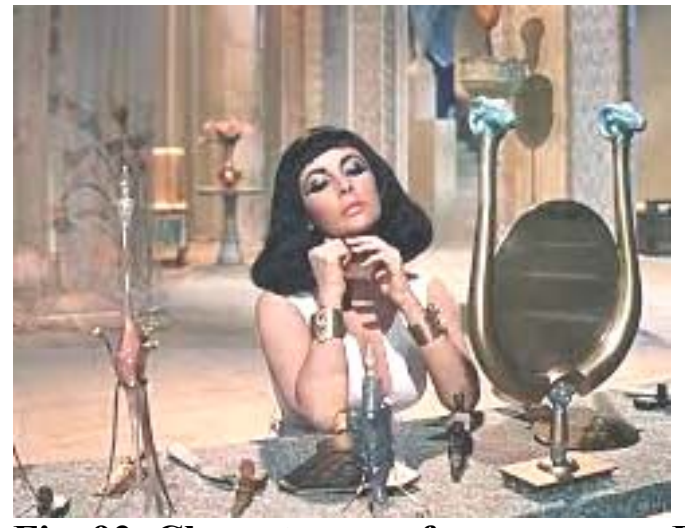

Fig. 92. Cleopatras perfumes.

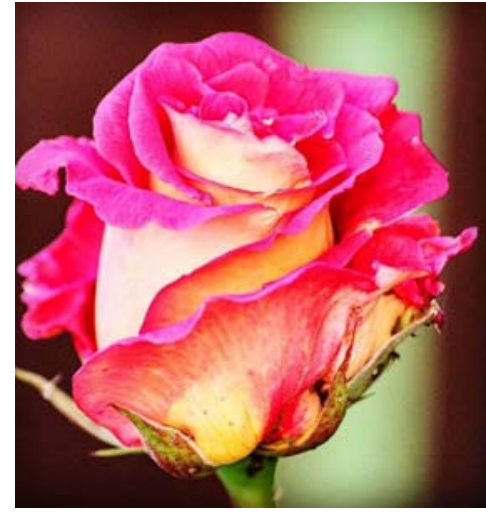

Fig. 93. The rose Cleopatra.

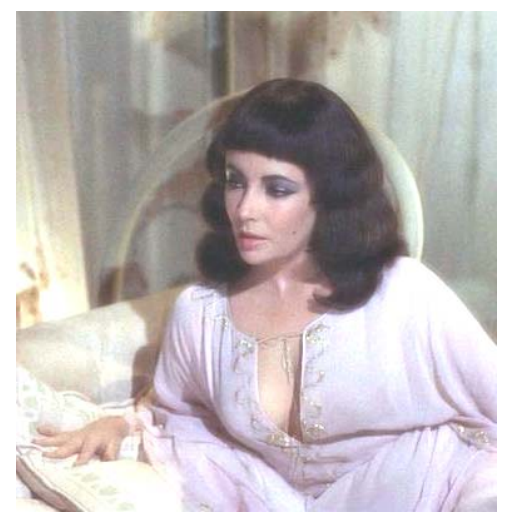

Fig. 94. Cleopatra (1963)

through a gothic lens, but integral to Haggard's reimagining of the narrative of Antony and Cleopatra... Floriography is not necessarily solely connected to a femme fatale but has wider implications relating to the tone, style and construction of the world of the novel - the duplicity, betrayal, tragedy and atmosphere of decay and death which run throughout the story of Haggard's Cleopatra. Cleopatra, with eyes 'hued like the Cyprian violet', is one of Rider Haggard's femme fatales. She is shrouded in scent throughout the story, reflecting the true use of perfumes in Ancient Egypt as well as her status as an enduring icon in the cultural imagination. Described as 'this wanton squandering the wealth of Egypt in chariots and perfumes'; the 'Perfume came from her hair and robes'; her 'perfumed breath'; and, her 'perfumed chamber' .... (Fig. 92. 93). 
Being concerned about the physical perpetuation of the body as a condition of eternal life, the Egyptians developed the art of embalming. For treating the dead, as for treating the gods and the living, they needed unguents, incense and perfume... Odour was an important constituent of the culture of the toilette.

Haggard cultivates a veritable poisonous garden for his historical romance, employing his extensive knowledge of Ancient Egypt and distorting traditional meanings within the language of flowers to enhance the tragic mood, to function as portents of doom, to ensnare or trick protagonists or antagonists accordingly. Cleopatra herself is a connoisseur of poisons. The idea that this femme fatale tests a series of poisons for their effectiveness on unwitting slaves, watching their slow demise in order to create a perfect death for herself is particularly macabre; "I have caused six different poisons to be given to these slaves and with an attentive eye have watched their working" [115].

Cleopatra, studying the tastes of the world's masters, is said to have spent an Egyptian talent, $£ 200$, for one night's adornment of a room with roses.Haggard corroborates this image of luxury and pomp by connecting Cleopatra and the rose, as she decorates with roses 'strewn ankledeep, that as the slaves trod them sent up their perfume' The aura of sensualism cultivated by Cleopatra helps to win Antony over at her feast in the ancient city of Tarsus (Fig. 53; 19; 87; 88; 89)

Roses are used as signs of the frustration experienced by Harmachis - in terms of both his goal to rule and his relationship with Cleopatra. Later in the narrative he attempts, with the help of Charmion, to seek vengeance for the earlier floriographic displacement by poisoning a chaplet of roses intended to be dipped in wine by Antony and Cleopatra to sweeten their beverages.

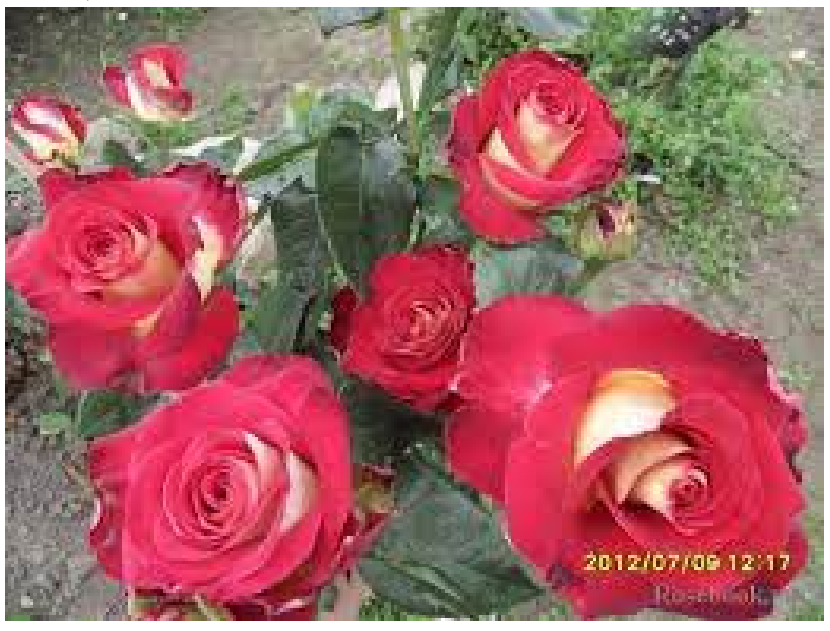

Fig. 95. Bush of the Cleopatra rose.

The plan is thwarted, but the use of roses, here arranged as a deadly trick, embellishes the crowning wreath of Haggard's poisonous garden. By rejecting the rose as an emblem of love and devotion, Haggard's roses exemplify voluptuousness, duplicity and tainted love [116].

Cleopatra filled her pillows with rose petals and strew them on the ground before Mark Antony to keep him aroused and committed (Fig. 94)... Cleopatra VII, probably inspired by the

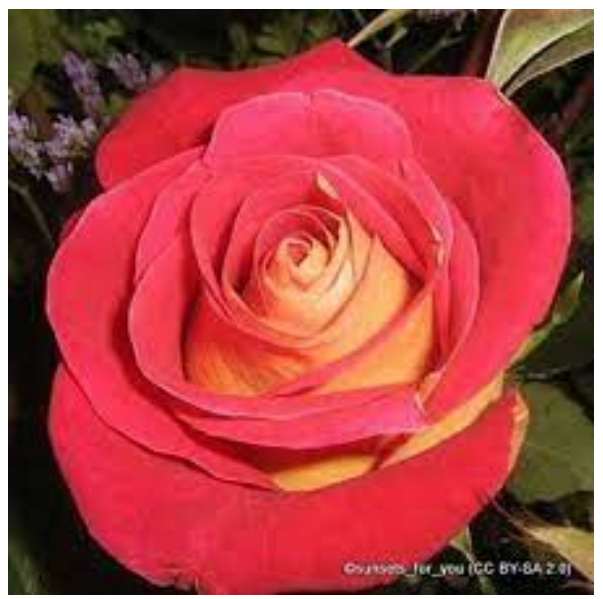
mythical origins of roses, used their petals Fig. 97. Bud of the Cleopatra rose (1994). during public appearances. She wanted to be remembered as a goddess who smelled like roses.

Legend has it that the most famous beauty of all, Cleopatra, had the sails of her boat slicked with fragrant oils before setting out to sea, so that Mark Antony would catch scent of her arrival before laying eyes on her face. In Rome, rosewater trickled from fountains - very much in fitting with the excess and luxury of the empire [21].

Drama, however, is not the only way to keep love alive see videos $[42 ; 34 ; 35]$. 
The rose has an ancient history as evidenced by 40-million-year-old fossilized remains [81].

At last, our heroine is the Cleopatra rose named after Cleopatra VII the Queen of the Ptolemaic Kingdom of Egypt (Fig. 98).

It is bred by W. Kordes \& Söhne rose (Germany, 1994). The Cleopatra Rose was introduced in South Africa by Ludwig's Roses as 'Peace of Vereeniging'. Kordes roses have a reputation for beauty and hardiness. This stunning rose has rich scarlet flowers with a golden underside and is in a bud form which is mainly single but can sometimes be in clusters. The Cleopatra Rose repeat flowers and has large, medium green foliage [45].

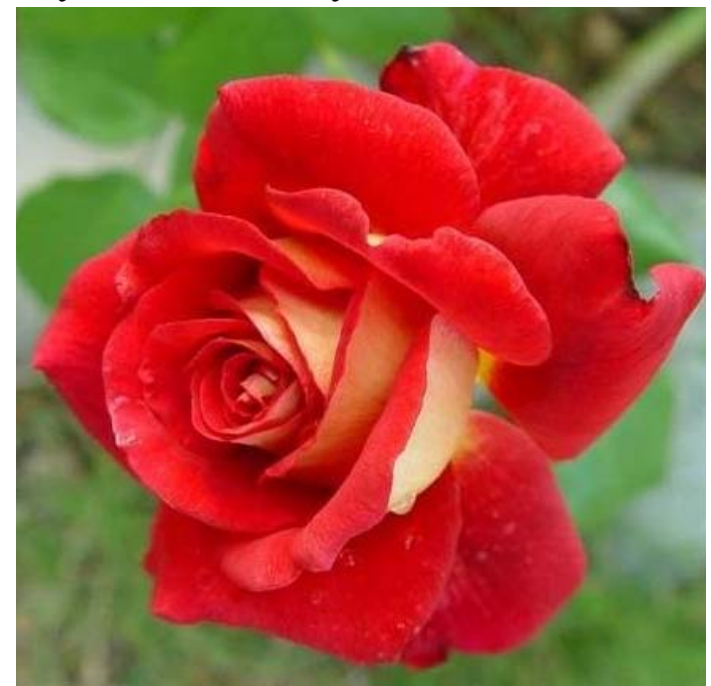

Fig. 98. The Cleopatra rose (1994).

Parentage of the Cleopatra rose: seed: Harmonie ${ }^{\circledR}$ (hybrid tea, Kordes before 1979) pollen: [ Fragrant Cloud (hybrid tea, Tantau 1963) × Peer Gynt] $\times$ [ Unknown $\times$ Norris Pratt ${ }^{\circledR}$ ] [48].
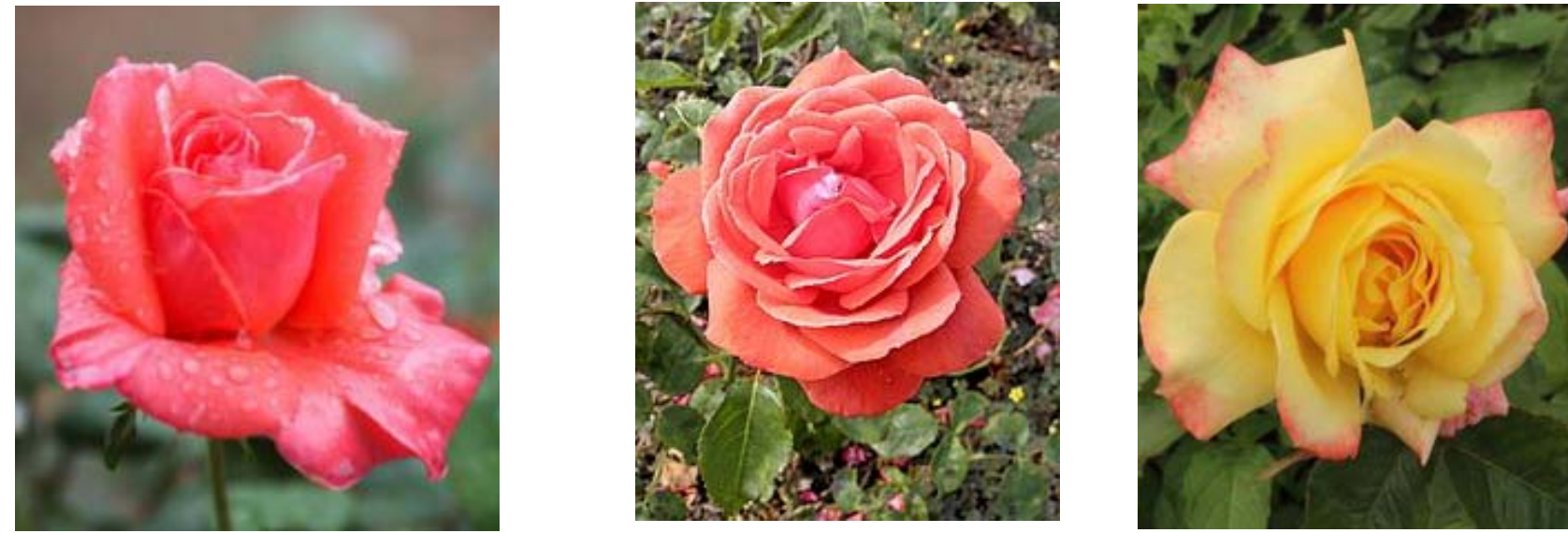

Fig. 98. Harmonie (orange pink) Rose. Fig. Rosa 99. 'Fragrant Cloud. $\quad$ Fig. 100. Rosa Peer Gynt.

\section{Unknown}

Seeds

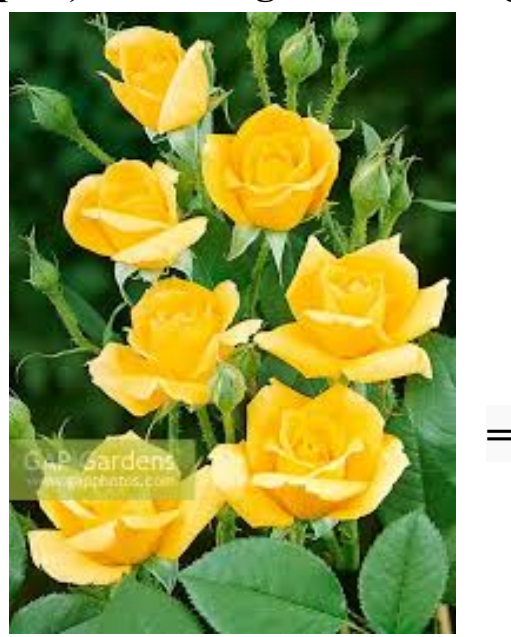

Fig. 101. Rosa Norris Pratt.

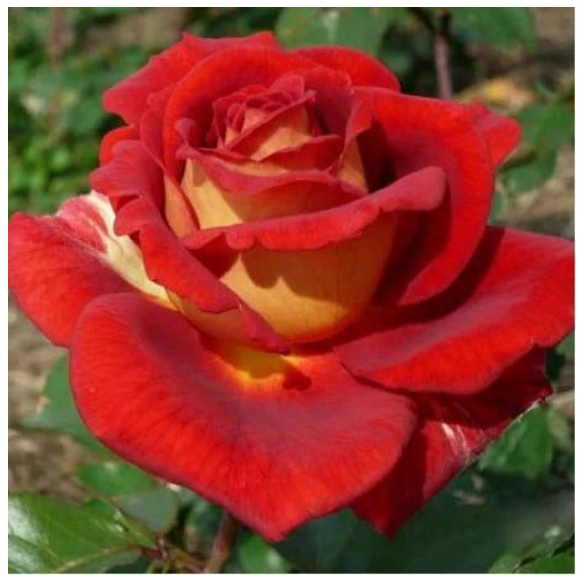

Fig. 102. Rosa Cleopatra. 


\section{Characteristics of the Cleopatra Rose}

Class: Hybrid tea.

Alternative cultivar names: 'Kleopatra', 'KORverpea', 'Cleopatra', 'Peace of Vereeniging' (Fig 103).

Registration name: 'KORverpea',

Exhibition name: Kleopatra ${ }^{\circledR}$

Hybridizer \& year: W. Kordes \& Sons, 1994

(Germany).

Introduced in South Africa by Ludwig's Roses as 'Peace of Vereeniging'.

Bloom size: Large: 4-5.

Bloom shape: High-centered (Fig. 104).

Petal count: very full: $41+$ petals.

Rose bloom color: Red blend.

Extra Color Info: Red blend, yellow reverse.

Rebloom: Florists rose. Other: Florists rose (Fig. 105).

Growth Habit: Medium, 3-4 feet, upright.

Fragrance: Mild.

Optimal growing zones: USDA zone 6 and warmer.

Plant Habit: Shrub.

Life cycle: Perennial.

Sun Requirements: Full Sun.

Soil pH Preferences: Moderately acid (5.6-6.0)

Slightly acid $(6.1-6.5)$

Neutral $(6.6-7.3)$

Slightly alkaline $(7.4-$ 7.8).

Plant Height: 3-4 feet. Plant Spread: 2-3 feet.

Leaves: Deciduous.

Flowers: Showy

Fragrant.

Flower Color: Bi-Color:

Red and yellow.

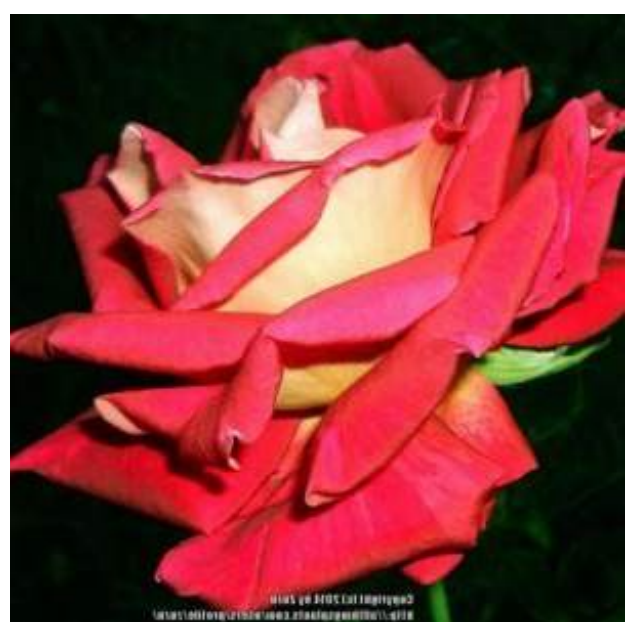

Flower Time: Spring

Summer

Uses: Cut Flower.

Fall (Fig. 106).

Wildlife Attractant: Bees.

Propagation: Cuttings: Stem.

Other methods: Cuttings: Tip.

Miscellaneous: With

thorns/spines/prickles/teeth (Fig. 104).

Parentage: Harmonie $\mathrm{x}$ [(Fragrant Cloud $\mathrm{x}$

Peer Gynt) x (Unknown x Norris Pratt)].

Child plants: 2 child plants: Rosa

'Curiosity', Rosa 'Over the Moon' [105; 48].

Fig. 106. Bushes of the roses Cleopatra in the garden.

Fig. 103. Rosa "Cleopatra" (1994).

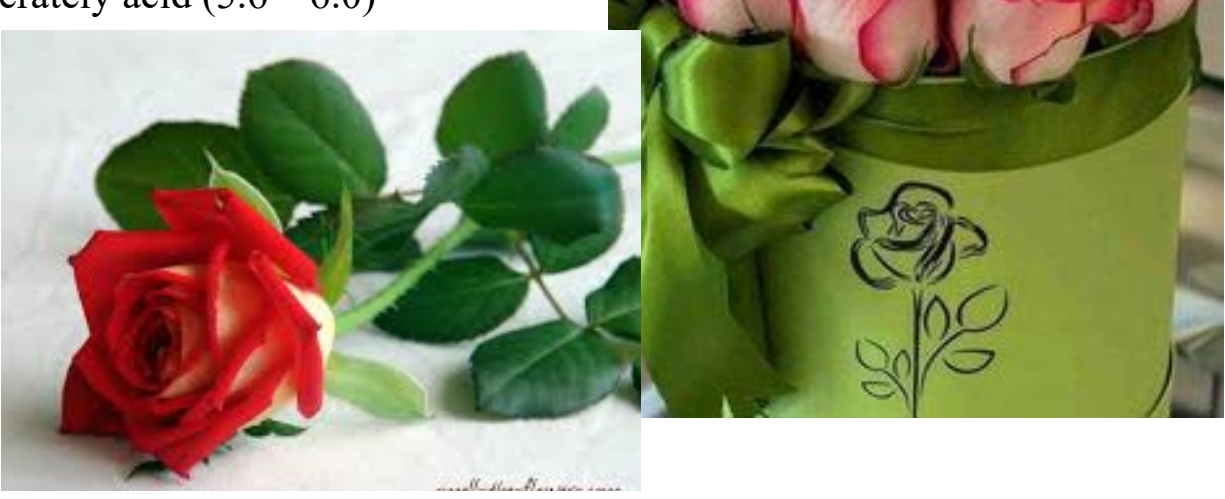

Fig. 104. Stem and leaves. Fig. 105. Bouquet of the roses Cleopatra.
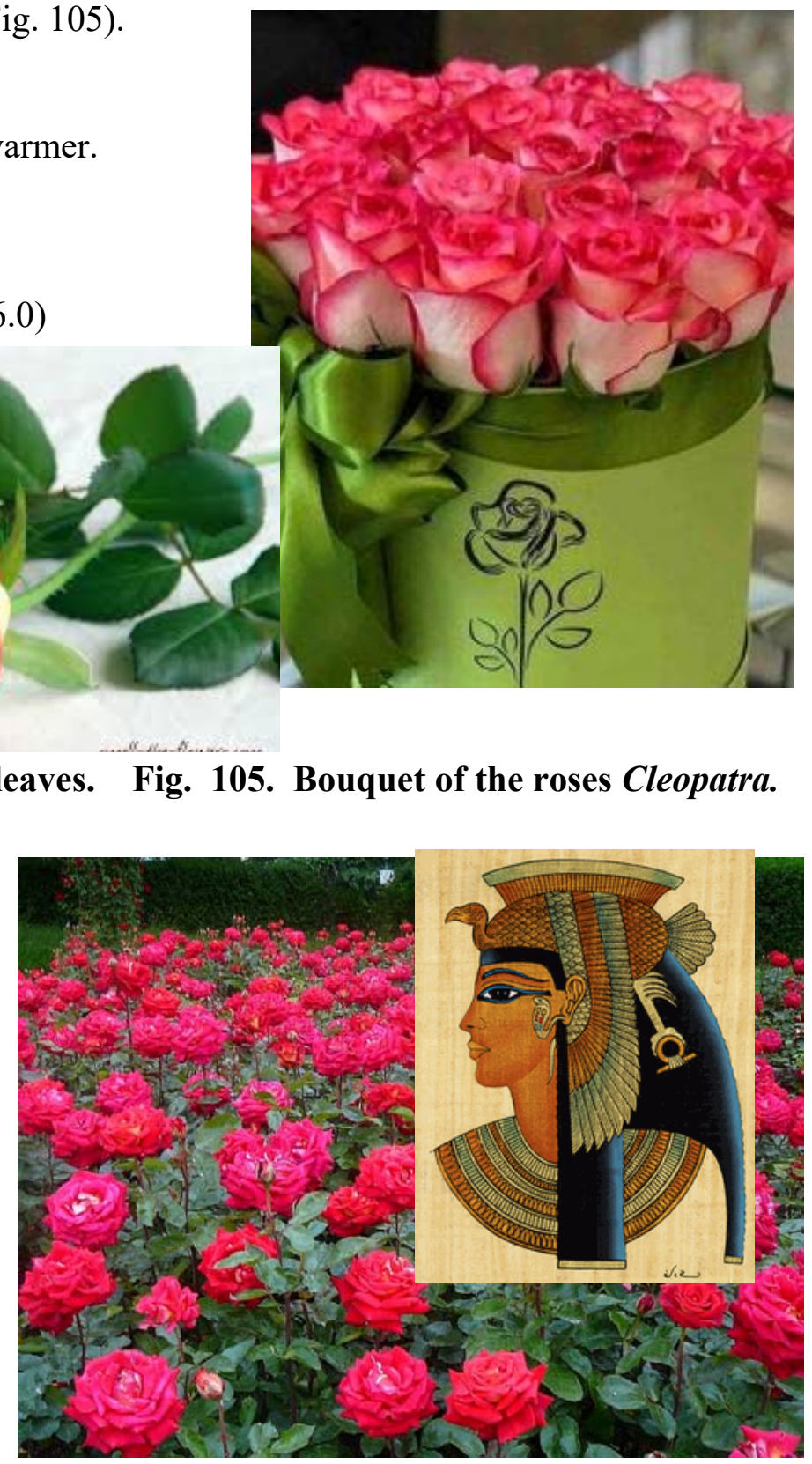

Fig. 107. Image of Cleopatra. 


\section{References}

1. Agren Liisa. Shakespeare Saturday: Antony and Cleopatra. URI : https://shakespeareforabsolutebeginners.com/2016/11/26/shakespeare-saturday-antony-andcleopatra/

2. Aguilar Emily, College Bryn Mawr. Masculinity, Power, and Death: Cleopatra in Boccaccio's De Mulieribus Claris. URI : https://sophia.smith.edu/dies-legibiles/wpcontent/uploads/sites/602/2021/05/Cleopatra.pdf

3. American Rhetoric: Movie Speech: "Julius Caesar" (1953). Marc Antony Addresses Roman Citizenry on the Death of Julius Caesar. URI :

https://www.americanrhetoric.com/MovieSpeeches/moviespeechjuliuscaesarantony.html

4. Ancient Egypt: The Pharaoh civilisation | Educational Videos for Kids

https://www.youtube.com/watch? $\mathrm{v}=8$ Tbv7anqXk

5. Antony and Cleopatra | Act 1, Scene 3| Royal Shakespeare Company. URI : https://www.youtube.com/watch?v=M0B1xgqAdkM

6. "Antony and Cleopatra" - HBO 'Rome' documentary [ENG subs] URI:

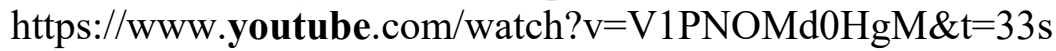

7. Antony and Cleopatra stage footage | Act V, scene 2 | 2013 | Royal Shakespeare Company. URI : https://www.youtube.com/watch?v=d6wGHrgrEn4

8. Antony and Cleopatra. Synopsis and plot overview of Shakespeare's Antony and Cleopatra. URI :

https://www.shakespeare.org.uk/explore-shakespeare/shakespedia/shakespeares-plays/antony-andcleopatra/

9. Antony and Cleopatra. Summary. The Tragedy of Love in "Antony and Cleopatra». URI : https://www.pacc.in/e-learningportal/ec/admin/contents/36_MEN31_2020111003523834.pdf

10. Arensky A.S. Egyptian Nights [Ballet] URI : https://www.naxos.com/mainsite/blurbs_reviews.asp?item_code $=8.225028 \&$ catNum $=225028 \&$ filet ype $=$ About $\% 20$ this $\% 20$ Recording\&language $=$ English

11. Asterix and Cleopatra (1968) VS Asterix \& Obelix: Mission Cleopatra (2002). URI https://www.youtube.com/watch?v=7dKUR14U_Xc with English subt.

12. Asterix \& Obelix: Mission Cleopatre (2002). Cleopatra Yells At Caesar. URI : https://www.youtube.com/watch?v=zLw58HxavxU

13. Asterix and Cleopatra (1968) [Eng Dubbed FULL MOVIE]. URI : https://www.youtube.com/watch?v=p5kGlq0fTVw Cartoon.

14. Bass Trystan L. Let's Get Epic With Cleopatra (1963). URI : http://www.frockflicks.com/cleopatra-1963/

15. Birrell Oliver. What Cleopatra Really Looked Like According To Scientists. URI : https://fabiosa.com/lbmkt-3090-rslb-aulb-pdmt-phkan-what-cleopatra-really-looked-like-accordingto-scientists/

16. Bright Celeste. Dante's Infero. The second circle of Hell: Lust. URI : https://study.com/academy/lesson/dantes-inferno-second-circle-of-hell-punishmentsdescription.html

17. Britannica. 2020. What did Cleopatra look like. URI : https://www.britannica.com/story/what-did-cleopatra-look-like.

18. Brittaney B. 'Cleopatra' Movie Review - An Imperfect Spectacle With Elizabeth Taylor. URI: https://www.silverpetticoatreview.com/2019/07/31/cleopatra-movie-review-1963/

19. Brooke Jill. How Flowers Have Been Used For Seduction Throughout History. URI: https://flowerpowerdaily.com/how-flowers-have-been-used-for-seduction-throughout-history/

20. Brooke Jill. The Tomb of Flower-Loving Cleopatra Unearthed. URI : https://flowerpowerdaily.com/flower-loving-cleopatras-tomb-unearthed-in-science-channel-special/

21. Buchan Ella. History of perfume: the story behind our favourite scents. The Telegraph. 1 July 2016. URI : https://www.telegraph.co.uk/beauty/skin/creed-fragrance/history-of-perfume/

22. Burgess Adam. A Guide to Dante's 9 Circles of Hell. ThoughtCo, Feb. 16, 2021. URI : thoughtco.com/dantes-9-circles-of-hell-741539. 
23. Caesar's Murder Scene. Largo di Torre Argentino | Journey Thru History. URI : https://www.youtube.com/watch?v=SenVdnzyA_E
24. Caesar
and
Cleopatra.
Documentary.
URI :|

https://www.youtube.com/watch?v=J58iriWo3fw

25. Charlton Heston Mark Antony speech from movie "Julius Caesar" (1970). URI : https://www.youtube.com/watch?v=0bi1PvXCbr8

26. Cleopatra. URI : https://en.wikipedia.org/wiki/Cleopatra

27. Cleopatra (1912). FULL Movie. Helen Gardner, Pearl Sindelar, Miss Fielding. URI : https://www.youtube.com/watch?v=hWEWwqOk9zY

28. Cleopatra (1934) (Cecil B. DeMille) (Masters of Cinema) Official Trailer. URI : https://www.youtube.com/watch?v=Dhz00dsSrMk

29. César e Cleópatra (1945, USA) (In English)

https://www.youtube.com/watch?v=25YFt6yV-Pg with English sudtitles

30. Cleopatra (1963, USA). URI : https://www.youtube.com/watch?v=RrRiJAWDiqQ

31. Cleopatra (1963, USA). Full movie. Director: Joseph L. Mankiewicz; Elizabeth Taylor, Richard Burton. URI: https://best-movies.watch/movie/8095-cleopatra/

32. Cleopatra (1963) Elizabeth Taylor Entrance into Rome Scene (HD). URI : https://www.youtube.com/watch?v=vB5Wv8IHVf0\&t=75s

33. Cleopatra (1963) - (Movie Clip) Caesar! Caesar! URI :

https://www.tcm.com/video/1222669/cleopatra-1963-caesar-caesar

34. Cleopatra (1963) - (Movie Clip) I Will Never Be Free Of You

URI : https://www.tcm.com/video/216549/cleopatra-1963-i-will-never-be-free-of-you

35. Cleopatra (1963) - (Movie Clip) How Will I Live? URI :

https://www.tcm.com/video/216550/cleopatra-1963-how-will-i-live

36. Cleopatra (1999, USA, Germany). Full Movie Action Adventure Romance Drama History. English And Spanish Subtitles. URI : https://www.youtube.com/watch?v=5DUxW2d YE

37. Cleopatra: A Sphinx Revisited; ed. Margaret M. Miles. University of California Press, 2011. $238 \mathrm{p}$.

38. Cléopâtre: an opera by Massne. URI : https://en.wikipedia.org/wiki/Cléopâtre

39. CLÉOPÂTRE de Jules Massenet (2004-05). "Je voulais m'endormir" (Acte 4) Carlos Álvarez (Marc-Antoine) Montserrat Caballé (Cléopâtre) Orquestra Simfònica del Gran Teatre del Liceu Direcció musical: Miquel Ortega. URI : https://www.youtube.com/watch? $\mathrm{v}=\mathrm{s}-\mathrm{j} \operatorname{coZ} 7 \mathrm{~J} 20$

40. Cleopatra \& Marc Anthony. (Cleopatra, 1963). URI :

https://www.youtube.com/watch?v=BLbL7BLRShk

41. Cleopatra and Marc Anthony. Part 2/2 - Great Figures of History - See U in History. URI : https://www.youtube.com/watch?v=I8GVU4apXHk

42. Cleopatra \& Anthony (Cleopatra, 1963): Their journey. URI : https://www.youtube.com/watch?v=e8L-7XRLwyY
43. Cleopatra's
Death
(Cleopatra,
1963
USA).
URI :

https://www.youtube.com/watch? $\mathrm{v}=\mathrm{VvU}$ 9ekshctY\&t=5s

44. Cléopâtre by Mikhail Fokine Teatro dell'Opera di Roma

Cléopâtre Gaia Straccamore Etoile Rome Opera Amoun Vito Mazzeo Principal Dancer Dutch National Ballet. URI :https://www.youtube.com/watch?v=9dKFbMiY4g8

45. Cleopatra -Climbing Rose. URI : https://bunkershillgardenshop.co.uk/cleopatra/

46. Cleopatra had herself wrapped in a carpet and smuggled into Caesar's quarters. URI : https://www.youtube.com/watch? $\mathrm{v}=$ ee8qeodKXBQ\&t=1s

47. Cleopatra. History Stories. April

https://www.history.com/topics/ancient-history/cleopatra

48. Cleopatra (hybrid tea, Kordes, 1994$). \quad$ URI :

https://www.helpmefind.com/rose/l.php?1=2.3639

49. Cleopatra Seduces Antony, 41 BC. URI :

http://www.eyewitnesstohistory.com/cleopatra.htm 
50. Cleopatra - Queen of Egypt | Women of History | Quick story for Kids in English. URI : https://www.youtube.com/watch?v=J5EkDf47KTc

51. Cleopatra: The Queen of Egypt - Part 1/2 - Great Figures of History - See U in History. URI : https://www.youtube.com/watch? $=$ BvWJiSNtT-o

52. Cleopatra's Gate in Tarsus. Turkish Archaelogical News. URI : https://turkisharchaeonews.net/object/cleopatras-gate-tarsus

53. Cottier Cody. What Did Cleopatra Really Look Like? URI : https://www.discovermagazine.com/planet-earth/what-did-cleopatra-really-look-like

54. Critical Research: The Mystery of Cleopatra. URI : https:/hnd2baxterdesigns.wordpress.com/2020/11/01/critical-research-the-mystery-of-cleopatra/

55. Dahesh Museum of Art. URI :

http://www.daheshmuseum.org/portfolio/frederick-arthur-bridgmancleopatra-on-the-terraces-ofphilae/\#.YbXPB9VBzcs

56. Dante. The Divine Comedy. Summary and Analysis Canto V. URI : https://www.cliffsnotes.com/literature/d/the-divine-comedy-inferno/summary-and-analysis/canto-v

57. Death of Caesar, Largo di Torre Argentina, Rome, Italy, 15 April 2015

https://www.youtube.com/watch?v=9h3HVXFvD6k

58. DeMarko Michael. Antony Part 2: The Wars of the Second Triumvirate. URI: https://www.youtube.com/watch?v=jkpVGf6J4mY

59. Did Cleopatra wrap herself in a rug? URI : https://moviecultists.com/did-cleopatra-wrapherself-in-a-rug

60. Did Kathleen Martinez Find Cleopatra's Lost Tomb? / History Documentary / Reel Truth History. URI : https://www.youtube.com/watch?v=xYvK1XhlAx 8

61. Dr. Kathleen Martinez. In search of Cleopatra project. URI : https://www.facebook.com/drkathleenmartinez

61. Due notti con Cleopatra 1954 Mario Mattoli Alberto Sordi, Sophia Loren, Ettore Manni, Paul Mul.URI : https://www.youtube.com/watch?v=Y-NbXBYWlKY

63. Elizabeth Taylor Cleopatra Queen Of The Nile . URI : https://www.youtube.com/watch?v=uYeKA3SokU0

64. Fisher Warren. Illustrated History of the Roman Empire : From Ceasar's Crossing the Rhine (49 BC) to Empire's Fall, 476 AD. Publisher: Authorhouse. 2010. 140 p.

58. Friday in the atelier: "Cleopatra Testing Poisons on Condemned Prisoners" by Alexandre Cabanel. Atelier. February 16, 2007. URI : http://www.calladus.com/2007/02/friday-in-the-ateliercleopatra-testing-poisons-on-condemned-prisoners-by-alexandre-cabanel/

66. Händel. Giulio Cesare in Egitto. Con Montserrat Caballé, Díaz, Payne, Pierotti; Weikert 12.06.1982 Liceu. URI : https://www.youtube.com/watch?v=7kjM2UoKYBw

67. Garner Katherine. Dante's Inferno Ninth Circle of Hell: Punishments and Description. URI : $\quad$ https://study.com/academy/lesson/dantes-inferno-ninth-circle-of-hell-punishmentsdescription.html

68. Giulio Cesare in Egitto. URI : https://www.opera-online.com/en/items/works/giuliocesare-in-egitto-haendel-haym-1724

69. Goldsworthy Adrian. Antony and Cleopatra. Yale University Press. 480 p.

URI : https://www.npr.org/templates/story/story.php?storyId=130190252

70. Gott Ted. The Banquet of Cleopatra by the National Gallery of Victoria, National Gallery of Victoria, Melbourne, 2003, p. 102. URI : https://artsandculture.google.com/asset/thebanquet-of-cleopatra-giambattista-tiepolo/wwFHnS1 cmltkFw

71. Griep Stan V.. What Is A Kordes Rose: Information About Kordes Roses. URI : https://www.gardeningknowhow.com/ornamental/flowers/roses/kordes-roses.htm

72. Hughes-Hallett Lucy. Cleopatra: Histories, Dreams and Distortions. Pimlico, 1997. 417 p. Biography, Cultural, History Pilmico (Series). Tom 260.

73. History of Cleopatra | History For Kids | The Story of Cleopatra. URI : https://www.youtube.com/watch?v=Tb4myjW45_0 
74. Holovko T., Pet'ko L. The water lily species in the Royal Botanical Gardens at Kew (London): Victoria amazonica // Basic and applied research: current issues, achievements and innovations: materials of the first international scientific-practical Internet conference (Berdyansk, March 27, 2020). Berdyansk. 2020. Pp. 6-12.

75. Holovko T., Pet'ko L., Turchynova G. The rose "Leonardo da Vinci" by Alain Mayland // About the problems of science and practice, tasks and ways to solve them: abstracts of VI International scientific-practical conference (Milan, 26-28 October 2020). Milan, Italy: International Science Group, 2020. Pp. 51-59.

76. How Cleopatra looked in REAL LIFE. URI : https://www.youtube.com/watch?v=IGoE8b2o4u4

77. What did Cleopatra really look like? https://www.youtube.com/watch?v=UZ3Zmg9oTHE\&t=8s

78. How Octavian Succeeded in Discrediting Mark Antony. URI : https://www.youtube.com/watch?v=6dFc-k6wC7I

79. Julius Caesar | Act 2 Scene 2 | Royal Shakespeare Company. URI : https://www.youtube.com/watch? $\mathrm{v}=7 \mathrm{~S}-\mathrm{kodKA} E U$ with subtitles

80. Julius Caesar - Full Movie, dir. Fabio Cianchetti. (Multi Subs) by Film\&Clips. URI : https://www.youtube.com/watch?v=4nT6ifKkhrY

81. Incredible Acting - Richard Burton as Mark Antony in Cleopatra. URI : https://www.youtube.com/watch?v=EX_dPnYKUk

82. Kirilchuk N., Pet'ko L. The Style Icon And The Rose "Audrey Hepburn": Abstracts of the IV ${ }^{\text {th }}$ International Scientific and Practical Conference «Prospects and achievements in applied and basic sciences» (Budapest, February 9-12, 2021). Hungary. Budapest : Bookwire $^{\mathrm{TM}}$. 2021. Pp. 57-72.

83. Klymenko N., Pet'ko L. The image of British actress Audrey Hepburn in a rose named after "most beautiful woman of all time". Topical Issues of Science and Practice : abstracts of VII Sientific and Practical Conference (London, 02-06 November 2020). Great Britain, London : International Science Group, 2020. 781 p. Pp. 42-51.

84. Mark Antony. Documentary. Biography of the life of Mark Antony. URI : https://www.youtube.com/watch?v=_d-x1wnZ594

85. Mark Antony: I Died Roman. https://www.youtube.com/watch?v=cyDoy3gDUm8

86. Mark Antony: Lover of Cleopatra, Rival for an Empire. URI : https://www.youtube.com/watch?v=eHC51v39EmM

87. Massenet Jules: Cléopâtre. (Montserrat Caballé 2002) Full opera.URI : https://www.youtube.com/watch?v= MtY2AmMZjA

88. Morgun M., Pet'ko L. The Rose "Falstaff" and English Literature // Abstracts of the ${ }^{\text {st }}$ International Science Conference on Multidisciplinary Research (Berlin, January 19-21, 2021). Germany, Berlin : Bookwire ${ }^{\mathrm{TM}}$. 2021. Pp. 119-129.

89. Newman Jill N. A Brief Timeline of History's Most Famous Pearls. URI :

https://www.townandcountrymag.com/style/jewelry-andwatches/a35855588/famous-pearls-historytimeline/

90. 9 Circles of Hell (Dante's Inferno). URI :https://steemit.com/story/@rahat097/9-circlesof-hell-dante-s-infern

91. Novak T., Pet'ko L. The beaver as a national symbol of Canada // Current issues of science: materials and international scientific practice. Internet conference (Berdyansk, April 30, 2020). Berdyansk: BSPU, 2020. C. 26-35.

92. Pet'ko L. V. Brainstorming and the formation of professionally oriented foreign language teaching environment in the conditions of university (for the specialties 023 "Fine Arts" and 022 "Design") // Economics, management, law : challenges and prospects: Collection of scientific articles. Psychology. Pedagogy and Education. Discovery Publishing House Pvt. Ltd., New Delhi, India. 2016. P. 214-217. URI http://enpuir.npu.edu.ua/handle/123456789/10739 
93. Pet'ko L. Multicultural upbringing of students and the formation of professionally oriented foreign language teaching environment // Perspectives of research and development : Collection of scientific articles. - SAUL Publishing Ltd, Dublin, Ireland, 2017. P. 164-170.

94. Pet'ko L. Teaching methods and the formation of professionally oriented foreign language learning environment in conditions of university. Intellectual Archive. 2016. Volume 5. No. 4 (July/August). Toronto : Shiny Word Corp., Canada. Pp. 73-87. URI http://enpuir.npu.edu.ua/handle/123456789/11084

95. Pet'ko L. V. Teaching of students' professionally oriented foreign language writing in the formation of professionally oriented foreign language learning environment // Economics, management, law: innovation strategy: Collection of scientific articles. Henan Science and Technology Press, Zhengzhou, China, 2016. P. 356-359.

96. Pet'ko L., Faut M. Rose: America's National Flower // Current Trends in the Development of Science and Practice: papers of the XXI ${ }^{\text {th }}$ International scientific and practical conference (15-16 June, 2020). Haifa, Israel. Publisher: International Science Groupe. 2020. Pp. 48-54. doi: 10.46299/ISG.2020.XXI

97. Pet'ko L., Holovko T. Victoria Amazonica: one of the amazing and beautiful plants in the Amazon rainforest // Research and Innovation: Collection of scientific articles. - Yunona Publishing, New York, USA, 2020. Pp. 154-159.

98. Pet'ko L., Turchynova G., Faut M. The Wild Prairie Rose: official State Flower of North Dakota and Iowa // Theoretical Foundations for the Implementation And Adaptation of Scientific Achievements in Practice : papers of the XXII ${ }^{\text {nd }}$ International scientific and practical conference (22-23 June, 2020). Helsinki, Finland. Publisher: International Science Groupe. 2020. Pp. 106-114. URI : http://enpuir.npu.edu.ua/handle/123456789/29966

99. Pet'ko L., Turchynova G., Sokolov T. The William Shakespeare Rose and the Rose in Shakespeare's works // Impact of modernity on science and practice: Abstracts of XVIII International Scientific and Practical Conference. Boston, USA 2020. Pp. 116-125.

100. Porokhnitska A., Pet'ko L., Turchynova G. Oscars best actress winner Julie Andrews and a beautiful rose named after her / Actual problems of modern science and practice : the XXXII International Science Conference (Boston, June 29-July 02, 2021). USA. Boston : Bookwire ${ }^{\mathrm{TM}}$. 2021. Pp. 39-53.

101. Pruitt Sarah. Did Cleopatra Really Die by Snake Bite? History Stories. April 26. 2021. URI : https://www.history.com/news/cleopatra-suicide-snake-bite

102. Reginald Arthur (fl. 1881-1896). The Death of Cleopatra. URI :

https://www.christies.com/en/lot/lot-3935132

103. Renee Fleming uses Gorgeous Chest Voice for her Sensual Cleopatra. URI: https://www.youtube.com/watch? $\mathrm{v}=$ KgadYCfmLzo\&t=36s

104. Rice A., Rice Ch. Ramses the Damned: The Passion of Cleopatra. New York: Anchor Book: 2017.

URL :

https://books.google.com.ua/books?id=ADM3DgAAQBAJ\&pg=PT29\&lpg=PT29\&dq=The+magic + of + the + queen + of + Egypt + in + the + rose + "Cleopatra" \&source=bl\&ots $=x q w M v C l Y K W \& s i g=A C f U$ 3U3SeYIxJMEVoRwUrW0omhJLXc-mZw\&hl=ru\&sa=X\&ved=2ahUKEwjJIby98T0AhXcR_EDHQtWA9UQ6AF6BAgeEAM $\# \mathrm{v}=$ onepage $\& \mathrm{q}=\mathrm{The} \% 20$ magic $\% 20 \mathrm{of} \% 20$ the $\% 20$ queen $\% 20$ of $\% 20$ Egypt $\% 20$ in $\% 20$ the $\% 20$ rose $\% 20$ "Cleopatra" $\& \mathrm{f}=$ false

105. Rose (Rosa 'Kleopatra') in the Plants Database. URI : https:/garden.org/plants/view/4059/Rose-Rosa-Kleopatra/

106. Royal Shakespeare Company - Julius Caesar, Act 3 Scene 1 - stage scene - NY. URI : https://www.youtube.com/watch? $=90 X T Q-C j 9 k I \quad$ with subtitles

107. Royster F. Becoming Cleopatra: The Shifting Image of an Icon. Publisher : Palgrave Macmillan. 2003. 271 p. URI : https://www.amazon.com/Becoming-Cleopatra-Shifting-ImageIcon/dp/1403961093

108. Schemm Paul. Mummies and statues point to Cleopatra tomb. URI :

https://www.nbcnews.com/id/wbna30309472 
109. 'Sensational' Egypt find offers clues in hunt for Cleopatra's tomb. The Gardian. 2020 July 12. URI : https://www.theguardian.com/science/2020/jul/12/sensational-egypt-find-offersclues-in-hunt-for-cleopatras-tomb

110. Seymour Miranda. Cleopatra: A Life by Stacy Schiff. The Guardian. Saturday 22 Jan 2011. URI : https://www.theguardian.com/books/2011/jan/22/cleopatra-life-stacy-schiff-review

111. Shevchenko V., Pet'ko L. William Shakespeare rose named after 'British Man of the Millennium' // Fundamental and applied research: current issues, achievements and innovations: materials of the first international scientific-practical Internet conference (Berdyansk, March 27, 2020). Berdyansk. 2020. Pp. 37-44.

112. Show B. Caesar and Cleopatra (USSR, 1979). Teleplay (directed by A. Belinsky), Act 1 , in ch. starring Innokenty Smoktunovsky and Elena Koreneva. URI: https://www.youtube.com/watch?v=Uh_YckEoIBw

113. Show B. Caesar and Cleopatra (USSR, 1979). Teleplay (directed by A. Belinsky), Act 2, in ch. starring Innokenty Smoktunovsky and Elena Koreneva. URI: https://www.youtube.com/watch?v=JUawfJuRzAw

114. Stepanchenko D., Pet'ko L. The rose Sweet Juliet is a tribute to young love // Current issues of science: materials of the first international scientific practice. Internet conference (Berdyansk, April 30, 2020). Berdyansk: BSPU, 2020. Pp. 36-46. URI: http://enpuir.npu.edu.ua/handle/123456789/28862

115. Stewart Jemma. H. Rider Haggard's Gothic Garden. URI : https://euppublishingblog.com/2020/10/14/flowers-symbolism-1/

116. Stewart Jemma. The Poisonous Flowers of H. Rider Haggard's Cleopatra: Part Three. Rose. URI : https://euppublishingblog.com/2020/10/16/flowers-symbolism-3/

117. Straus Oscar. Die Perlen der Cleopatra. (1923) Operetta: libretto Julius Brammer, Alfred Grünwald. Orchester der Komischen Oper Berlin, Lindenquintett Berlin. 03 December 2016. Dagmar Manzel Cleopatra: Queen of Egypt, Peter Renz: Mark Antony, triumvir of the Roman Empire. URI : https://www.youtube.com/watch?v=p85WFYP5G_k

118. 10 Little-Known Facts About Cleopatra. URI : https://www.history.com/news/10-littleknown-facts-about-cleopatra

119. The Allure of Cleopatra. URI : https://penelope.uchicago.edu/ grout/encyclopaedia_romana/miscellanea/cleopatra/waterhouse.html

120. The Ancient Egypt: 5 things you should know. History for kids. URI : https://www.youtube.com/watch? $\mathrm{v}=\mathrm{V} 3 \mathrm{C} 6 \mathrm{szgcIY}$

121. The Mystery of Cleopatra's burial. URI : https://www.grunge.com/240830/the-mysteryof-cleopatras-burial/

122. The Pearls of Cleopatra. URI : https://www.eat-berlin.de/en/the-pearls-of-cleopatra/

123. The Ptolemaic Kingdom. URI : https://en.wikipedia.org/wiki/Ptolemaic_Kingdom

124. The Real Cleopatra $\mid$ National Geographic. URI : https://www.youtube.com/watch? $\mathrm{v}=\mathrm{Xy} \_$qnbqGZs

125. The Real Reason Cleopatra Killed Herself. URI : https://www.youtube.com/watch?v=BJX1YQXQQPI with sub.

126. Theda Bara in the film Cleopatra (1917) + Interview. URI : https://www.youtube.com/watch? $v=$ rjbzCcAzSSo

127. Trow M. Cleopatra: Last Pharaoh of Egypt. Publisher: Robinson, 2013. $256 \mathrm{p}$

128. Turchynova G, Pet'ko L., Novak T. The Rose "Ophelia" and Flower Symbolism in "Hamlet". Intellectual Archive. Toronto: Shiny Word.Corp. (Canada). 2021. Vol. 10. No. 1. (January/March). Pp. 68-93. DOI: 10.32370/IA_2021_03_10

129. Ullman B.L. Cleopatra's Pearls. The Classical Journal. Vol. 52, No. 5 (Feb. 1957), pp. 193-201. URI : https://penelope.uchicago.edu/Thayer/E/journals/CJ/52/5/Cleopatras_Pearls*.html

130. Walker S., Higgs P. Cleopatra of Egypt : from history to myth. Princeton, N.J. : Princeton University Press, [2001] (C2001. 384 p. 
131. Wallenfeld Jeff. What Did Cleopatra Look Like? URI : https://www.britannica.com/story/what-did-cleopatra-look-like

132. Was Cleopatra One Of History's Biggest Killers? Portrait Of A Killer (Ancient Egypt Documentary). URI : https://www.youtube.com/watch?v=YFWRe2TqyPk

133. Weird Things You Didn't Know About Cleopatra. URI :

https://www.youtube.com/watch? $v=j n a O \_H M e G Y c$

134. What Was The Real Cleopatra Like? | Egypt Thru The Ages (Part 4/4) | Absolute History. H3

135. When did Queen Cleopatra die and who killed her? URI : https://www.historyextra.com/period/ancient-egypt/queen-cleopatra-when-die-how-killed-who-wasmark-antony/

\section{With subtitles}

136. Where Is Cleopatra's Tomb? URI : https://www.youtube.com/watch?v=sGU0x4qk7IM

137. William Shakespeare's 'Antony and Cleopatra' in 8 minutes: REVISION GUIDE | Narrator: Barbara Njau. URI : https:/www.youtube.com/watch?v=T669KYdsGxM

138. Windham Arielle. Circles one through four. URI : https://study.com/academy/lesson/dantes-inferno-fifth-circle-of-hell-punishments-description.html

\section{Translation of the Title, Abstract and References to the Author's Language}

\section{УДК 582.639.11:811.111}

\section{Петько Л., Фаут М. Магія цариці Сгипту в троянді "Клеопатра".}

Запропоновано новий підхід у професійній підготовці майбутніх учителів, зокрема природничих наук (біології, ботаніки та ін.) крізь призму троянди, що названа на честь останнього фараона Єгипту, цариці Клеопатри. Автори розглядають троянду Клеопатра не через препарування рослини в лабораторії, а розкривають таємниці троянди Клеопатра через пізнання «життєвих істин», таким чином формуючи професійно орієнтований іншомовний освітній простір в умовах університету (іноземна мова, історія, географія, філософія, хімія, мистецтво (живопис, балет «Сгипетські ночі» Аренського, опери «Клеопатра» Массне та «Юлій Цезар в Сгипті» Генделя), кіно, література, психологія), долучаючи студентів до питань романтичного кохання, здатності до розуміння квіткових кодів, що закладено в троянді Клеопатра.

Ключові слова: цариця Клеопатра, троянда Клеопатра, Юлій Цезар, Марк Антоній, Рим, Сгипет, Данте, Шекспір, Хаґард, Гендель, троянди компанії «В. Кордес та сини» (Німеччина), студенти, іноземна мова, університет. 